\title{
A COMPARISON OF SAUDI AND UNITED STATES FACULTY \\ USE OF INFORMATION AND COMMUNICATION \\ TECHNOLOGY TOOLS
}

\author{
by \\ Mabark Alshahri \\ A dissertation submitted in partial fulfillment \\ of the requirements for the degree \\ of \\ Doctor of Education \\ in \\ Education \\ MONTANA STATE UNIVERSITY \\ Bozeman, Montana
}

April 2015 


\section{(C) COPYRIGHT}

by

Mabark Alshahri

2015

All Rights Reserved 


\section{DEDICATION}

I would like to dedicate this research paper to my father, my mother, my wife and my children. They have been a source of support, patience and help as I have pursued my research. 


\section{ACKNOWLEDGEMENTS}

First, I would like to thank Allah who helps me each day of my life, and gives me the strength to overcome the many difficult circumstances I have experienced while in the United States. I would also like to thank King Abdullah, then Imam Mohammed Ibn of Saud University, who gave me the opportunity to study in the United States and pursue further education under the scholarship and provision of Saudi Arabia. I would also like to thank my family. I thank my father who supported my decision to pursue further education and achieve my goals. I thank my mother who is patient and supportive despite the distance studying in the United States puts between us. Lastly, I thank my wife who has cared for and raised my children in this time and has always encouraged me through this process. Finally, I would like to thank the people at Montana State University for the chance to study and be a part of a community that has an excellent, supportive faculty who strives to help their students do their very best.

My deepest appreciation goes to the committee members: Dr. Michael Brody, who encouraged me to achieve my goals and oversaw my studying, and Dr. Arthur Bangert, who gave me excellent feedback about statistics and how to conduct research. I am also grateful to Dr. Nicholas Lux who gave me good survey suggestions and Dr. Lynn Kelting-Gibson who encouraged me and gave me helpful feedback about the development of my survey. I am thankful to all of them for spending many hours reading my dissertation drafts and providing me with insightful feedback to improve my work. 
TABLE OF CONTENTS

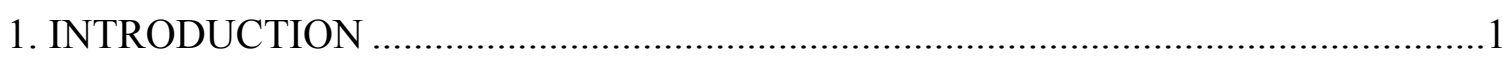

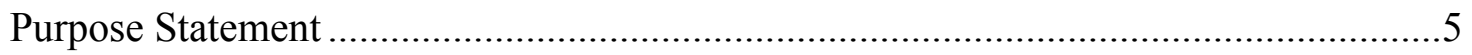

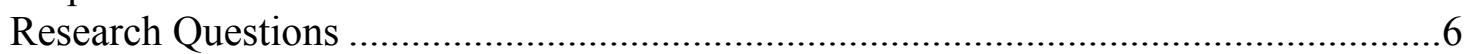

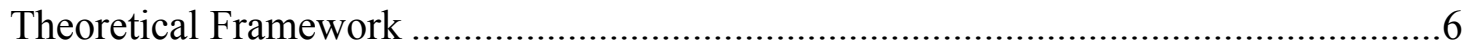

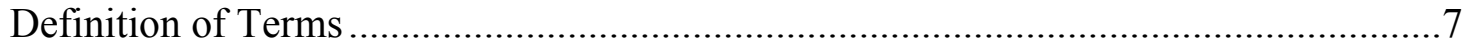

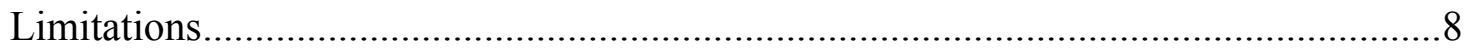

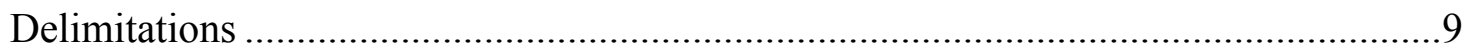

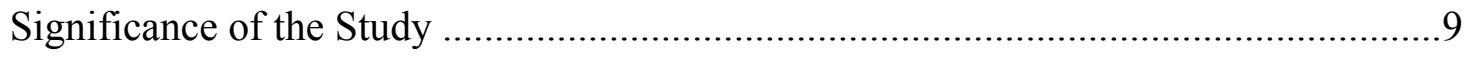

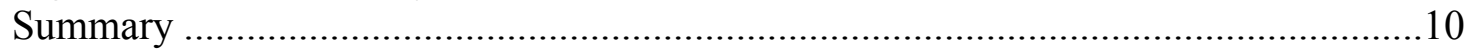

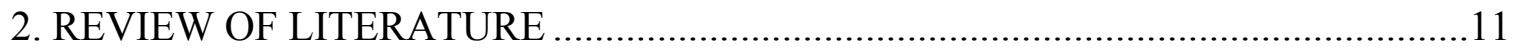

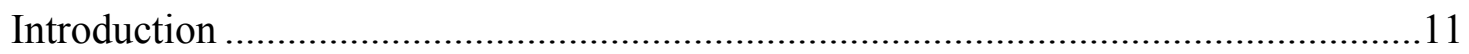

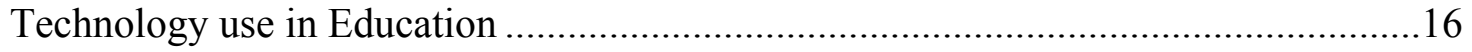

Issues Relating to Technology Integration in Higher Education ...............................18

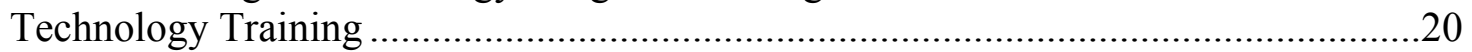

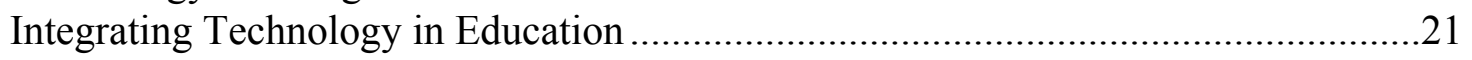

The Importance of Technology Integration for Education

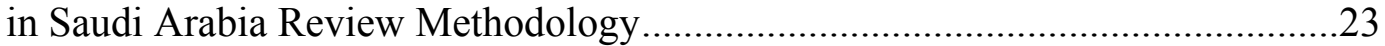

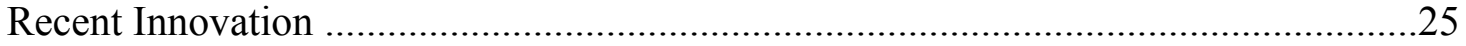

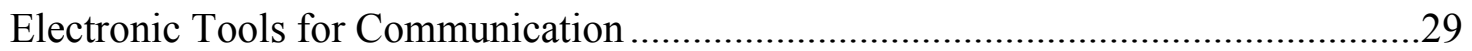

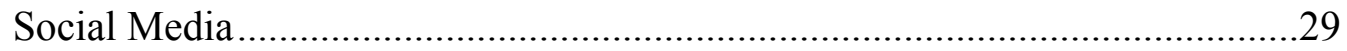

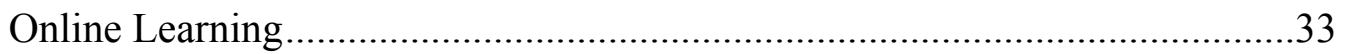

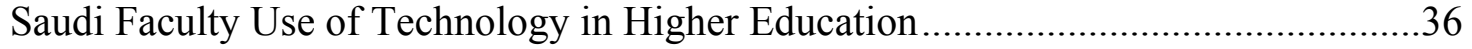

United States Faculty Use of Technology in Higher Education ................................42

Perceptions Influencing Technology Use and Adoption.......................................45

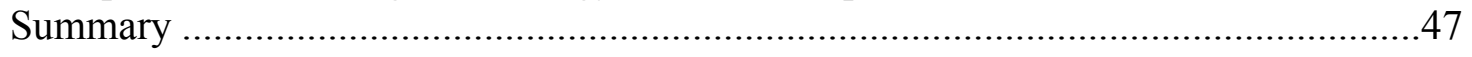

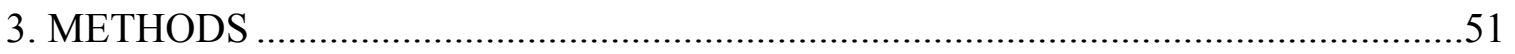

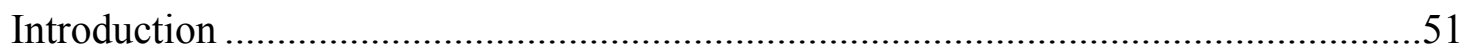

Research Questions ......................................................................................... 51

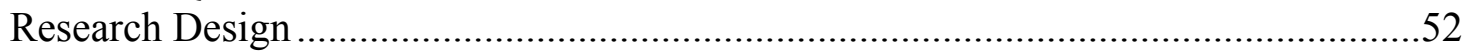

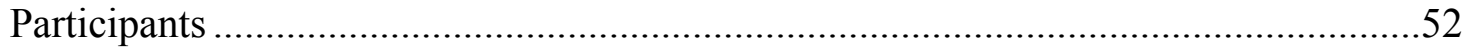

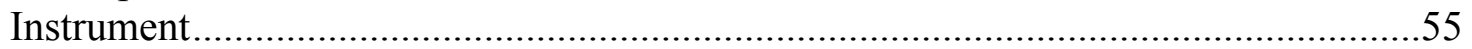

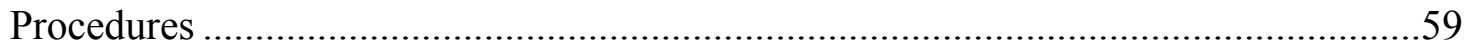

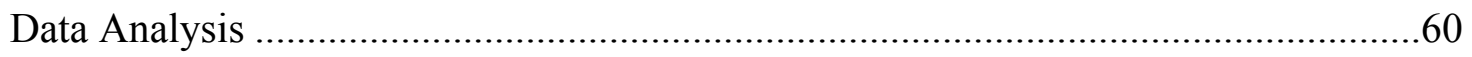

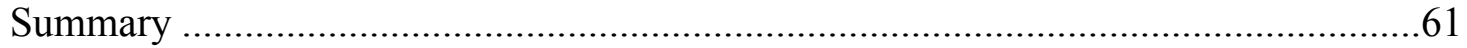




\section{TABLE OF CONTENTS CONTINUED}

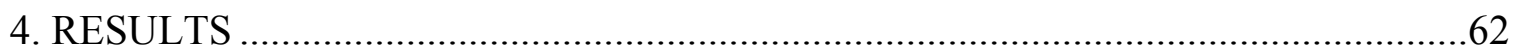

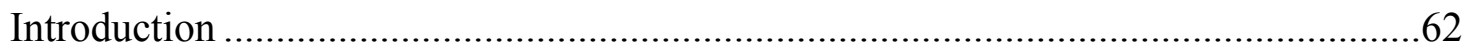

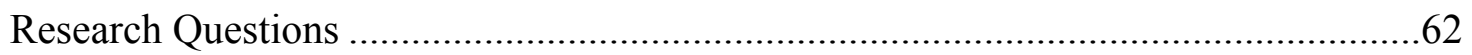

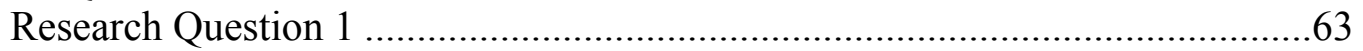

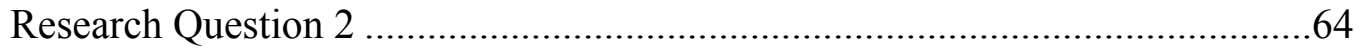

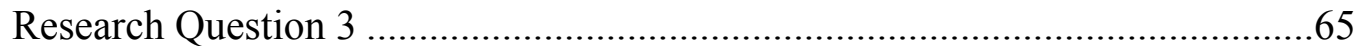

Path Analysis for Saudi Faculty ........................................................................6 66

Path Analysis for United States Faculty ..............................................................68

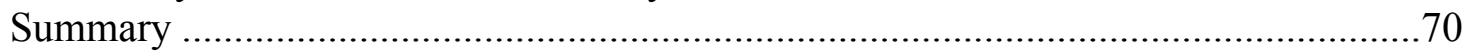

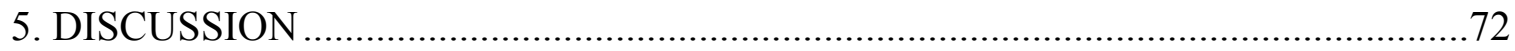

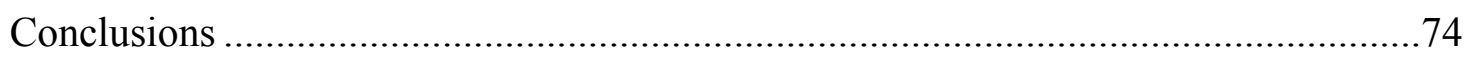

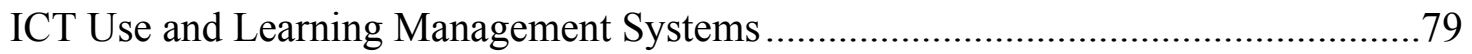

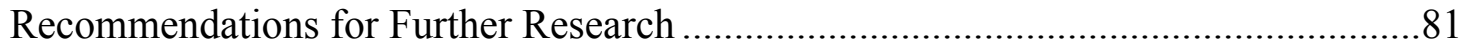

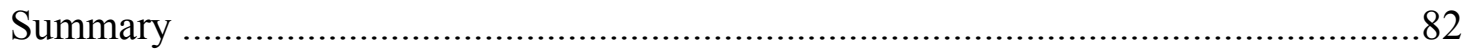

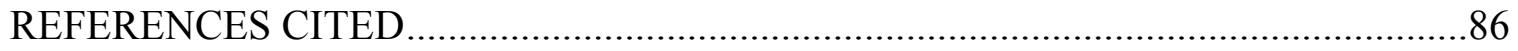

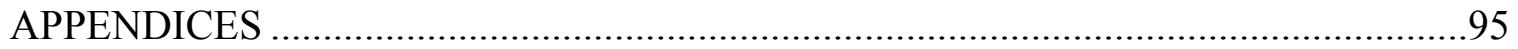

APPENDIX A: Online Survey English .......................................................96

APPENDIX B: Online Survey Arabic ...................................................... 104

APPENDIX C: Institutional Review Board................................................115 


\section{LIST OF TABLES}

Table

Page

1. Saudi and United States Faculty Institutions ........................................... 9

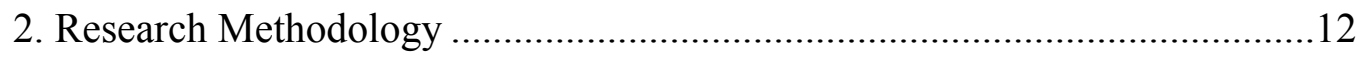

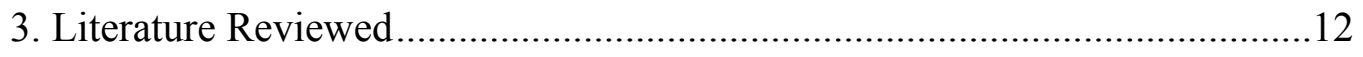

4. Saudi and United States Faculty Participants ..........................................52

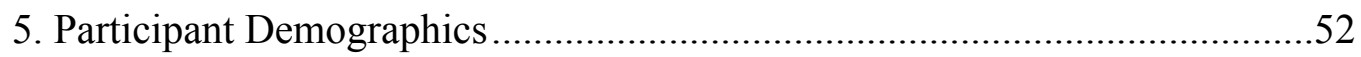

6. Saudi and United States Faculty Experience Using Electronic Tools.....

7. Factor Loadings, Means and Standard Deviations for Saudi Faculty ICT Attitude Items ..........................................................56

8. Factor Loadings, Means and Standard Deviations for United States Faculty ICT Attitude Items ...............................................58

9. Means and Standard Deviations for Frequency of ICT Use for Saudi and United States Faculty...

10. Means and Standard Deviations for Hours of Actual

ICT Use for Saudi and United States Faculty

11. Correlation Matrix of Variables for Saudi Faculty

Path Analysis .66

12. Correlation Matris of Variables for United States

Faculty Path Analysis.... 


\section{LIST OF FIGURES}

Figure

Page

1. Davis Technology Acceptance Model ..........................................................8

2. Literature Review Concept Map ...............................................................11

3. The Flipped Classroom Model...........................................................26

4. Faculty Class Use of Social Media by Site ...............................................30

5. Online Enrollments in United States Colleges

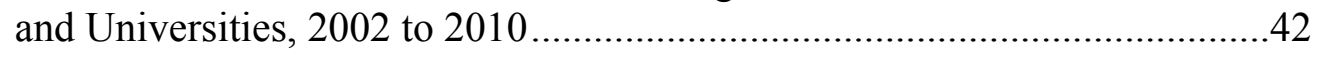

6. Frequency of Faculty Professional Use of Social Media...............................44

7. Technology Acceptance Model …......................................................46

8. Saudi Faculty Path Diagram ................................................................67

9. United States Faculty Path Diagram ............................................................69 


\begin{abstract}
The purpose of this descriptive and comparative study was to identify Information and Technology Communication (ICT) tools used by Saudi faculty and United States faculty, and to investigate relationships between their perceptions of ICT applications and ICT use. A questionnaire was sent to 292 Saudi faculty from six Saudi universities and 253 US faculty from five universities. The questionnaire gathered information about the use of and attitudes toward ICT applications. Results found that $65 \%$ of the United States faculty taught part or all of a course online as compared to only $26 \%$ of Saudi faculty. Saudi faculty used Social Media applications significantly more often than US faculty. Saudi faculty also reported using Google Documents, Photos and Website links significantly more often than US faculty while US faculty used podcasts and text documents significantly more often. Results from a path analysis of the relationships between ICT attitudes and actual ICT use based on Davis' (1993) TAM framework found that for Saudi faculty, system was the only variable significantly related to actual ICT Use. Ease of Use was significantly related to Perceived Value while Perceived Value was significantly related to Attitude Toward ICT Use. For US faculty, again, system was the only variable to have a significant relationship with Actual ICT use. Perceived Value was found to have a significant effect on Attitude Toward Use of ICT tools. The larger relationship between system use and actual ICT tool use for US faculty suggests that they had more access thus more experience using ICT tools than Saudi faculty. In addition, differences in attitudes toward ICT between Saudi and US faculty may be due Saudi faculty's primary use of social media and email applications as compared to US faculty's use a variety of more complex ICT applications including Audio. Overall results from this study suggest that Saudi faculty would benefit from training in the use of a variety of ICT application in addition to social media and email within the context of Learning Management Systems while US faculty would benefit from training in the use of social media applications as an instructional tool.
\end{abstract}




\section{CHAPTER ONE}

\section{INTRODUCTION}

Access to current technologies has offered a variety of electronic tools to support communication with students and instruction. The integration of technologies into our schools and universities has provided many positive benefits that support and enhance instruction. However, educational organizations are struggling to overcome the difficulty of effectively utilizing appropriate technologies that are designed to support instruction (Daher, 2014). According to Daher (2014), “teachers and professors need to adapt in order to better connect with their students and more effectively lead their classes" (p. 42). Access to technologies that support the use of audio, video, web conferencing and the Internet are providing many learning opportunities that were not available to students in the past. The vast amount of information accessible with a simple mouse-click allows teachers and students to access and experience information from countless resources.

While online learning and social media are being used internationally_especially in the United States — to support learning, there are few online learning resources available to students in Saudi Arabian universities. According to Alshawi (2011),

The widespread adoption of Internet applications in Saudi Arabia started in the late 1990s. Universities were among the first adopters of the technology and years later the Internet witnessed an unparalleled spread across campuses. Despite increased Internet connectivity in Saudi Arabian higher education institutions, there is little empirical research investigating the factors associated with the use of the Internet by faculty in teaching, research, and communication. (p. 81) 
Distance education over the years has evolved from correspondence courses delivered by mail, educational television, and most recently, online courses accessed by the Internet. It is estimated that approximately $25 \%$ of United States postsecondary students are enrolled in online coursework. Recent research conducted by the Gallup Organization trends toward increased online course offerings, and results from their survey of over 3,000 faculty and campus administrators found that over $71 \%$ indicated their institutions plan to expand online course offerings (Laschik \& Lederman, 2014).

It is clear that in the United States, as well as in other developed countries, online degree programs or partial online degree programs are available to post-secondary students (Anderson, 2008). This suggests that online coursework provides numerous benefits for students, including the convenience of accessing the courses at any time and place to engage with their instructor and other learners, both asynchronously and synchronously. In addition, facilitated learning occurs when knowledge and skills are situated within the context of learners' work or other personalized environments. For instructors, tutoring can be done at any time, materials can be updated immediately for learner access, and learning activities can be more customizable based on individual needs.

Saudi Arabia has the resources to provide new technologies, including interactive classroom management systems and social media, which can enhance their educational systems at both the K-12 and university level. However, there are still barriers to online learning that puts Saudi postsecondary students at a disadvantage (Al Mulhem, 2013). These barriers likely contribute the significant gap between educational opportunites in 
Saudi Arabia and the United States. The demand for higher education and cultural differences contribute to the differences in access to educational opportunities (Hamdan, 2014). According to Saudi National Center for Education statistics, the number of U.S. students in higher education in 2011 was 21.0 million and the number of U.S. universities is 2,680. (http://learningenglish.voanews.com/content/a-23-2005-05-11-voa183125492/124600.html).

The Ministry of Higher Education (MHE) was "established in 1975 to implement the Kingdom's higher education policy in the rapidly expanding sphere of postsecondary education. Prior to 1975, higher education was under the supervision and administration of the MoE.” (Al-Maliki, p. 2). Despite the forty-year existence of the MHE, currently, "the capacity of universities and colleges in Saudi Arabia is limited compared with the rapid growth of students applying for college education" (Alebaikan and Troudi, p. 49). However, Saudi Arabia does have the resources to provide new technologies, including interactive course room management systems and social media, which can enhance their educational systems at both the K-12 and university level. Utilization of existing resources and the adoption of such technologies would provide increased learning opportunities for Saudi citizens who reside in remote and isolated areas, and would accommodate the educational needs of a population of over twenty-nine million $(29,000,000)$ in a country with only twenty-five (25) universities. Currently, individuals from more remote areas must move to larger cities to earn degrees in higher education. (mohe.gov.sa, n.d.). The significant gap between KSA and USA in education is due to the differences between the population and the number of students. According to Saudi 
National Center for Education statistics, the number of U.S. students in higher education in 2011 was 21.0 million and the number of U.S. universities is 2,680. (http://learningenglish.voanews.com/content/a-23-2005-05-11-voa183125492/124600.html).

Because the number of Saudi students in higher education has increased, use of technology is very important to provide opportunities for all students. According to the Saudi Higher Education Statistic Center, in 2013 the number of students in higher education reached 1,932,208 students (www.mohe.gov.sa/ar/default.aspx). Also, the Saudi government struggles to improve education by sending many students to many countries through the Custodian of the Two Holy Mosques Program Foreign Scholarship. Since the program's inception in 2005, the number of scholarships for Saudis jumped from 5,000 scholarships to the United States in that year to reach beyond 150,000 students scholarships in 2014 dispersed over more than 30 countries (www.mohe.gov).

An additional cultural limitation prevents Saudi Arabian women from travelling to other cities; this severely limits their opportunities for educational advancement. The Saudi government has addressed the recognized disparity in educational opportunities available to men and women. The government instituted a series of initiatives for enhancing access to higher education for women including the establishment of Princess Noura bint Abdul Raman University for women, which is designed to become the world's largest center of higher education for women worldwide. Currently, more than 300 higher education colleges exist for women in the country alongside universities and women represent more than $56.6 \%$ of the total number of Saudi university students and 
more than $20 \%$ of those benefiting from overseas scholarship programs. (Saudi Ministry of Higher Education, p.1).

Alebaikan and Troudi write that the Saudi Ministry of Higher Education has further "encouraged the use of information technology (IT) for teaching and learning among its faculties and students" and the ministry is also continuously developing projects to "provide adequate IT infrastructure as well as content development for higher education students" (p. 49). As referenced earlier with regards to the capacity issues at Saudi universities, the Ministry of Higher Education is working to achieve an integration between web based and traditional instructions within the university systems. (Alebaikan and Troudi, 2008). Despite this support, and despite the fact that there are many new technologies available to support learning, there are few studies that have investigated how instructors in Saudi Arabia and the United States use technologies such as Learning Management Systems, social media technologies and other productivity software to support learning.

\section{$\underline{\text { Purpose Statement }}$}

The purpose of this comparative descriptive study was to identify the types of Information and Technology Communication (ICT) tools Saudi faculty and United States faculty use to support learning in higher education. In addition, this study was undertaken to explore the relationship between actual Information and Technology Communications Use and Saudi Faculty and United States faculty's perceptions of their ease of use, perceived value and attitudes toward use. Davis's Technology Acceptance Model (1993) 
was used as the model for investigating these relationships. Results from this study will inform leadership in the Saudi Ministry of Higher Education about the types of technologies higher education faculty in the United States use currently to support communications with students and for learning in higher education.

\section{Research Questions}

1. What Information and Communication Technology tools do Saudi and United States faculty indicate that they use most frequently for communicating with students and for instruction?

2. How many hours per week do Saudi and United States faculty estimate they use ICT tools to communicate with their students and for instruction?

3. How do Saudi and United States faculty perceptions of ease of use, perceived value, attitude toward the use of Information and Communication Technology and actual ICT use relate to one another?

\section{Theoretical Framework}

Davis's Technology Acceptance Model (1989) provides a foundation for understanding factors that determine use of Information and Communication Technology tools. The Technology Acceptance Model (TAM) is based on Fishbein and Ajzen's (1975) attitude paradigm, which theorizes that external stimuli (for example an ICT system) are causally linked to beliefs, attitudes and behavior. Using Fishbein and Ajzen's theory Davis proposed that attitude toward using technology is a function of two beliefs; 
perceived usefulness and perceived ease of use. Davis proposes that perceived usefulness is the degree to which an individual believes that technology would improve his/her job performance. The higher an individual's perceived usefulness the more likely they are to adopt the new technology (Rogers, 2003). Perceived ease of use is defined as the degree to which a technology is easy to understand, operate and is free from effort (Davis, 1989; Rogers, 2003). Technologies that are perceived to be less complex to use have a higher possibility of acceptance and is an important determinant in technology adoption decisions (Davis, 1989). The Technology Acceptance Model first proposed and researched by Davis in 1989 is represented in Figure 1.

Figure 1. Davis Technology Acceptance Model

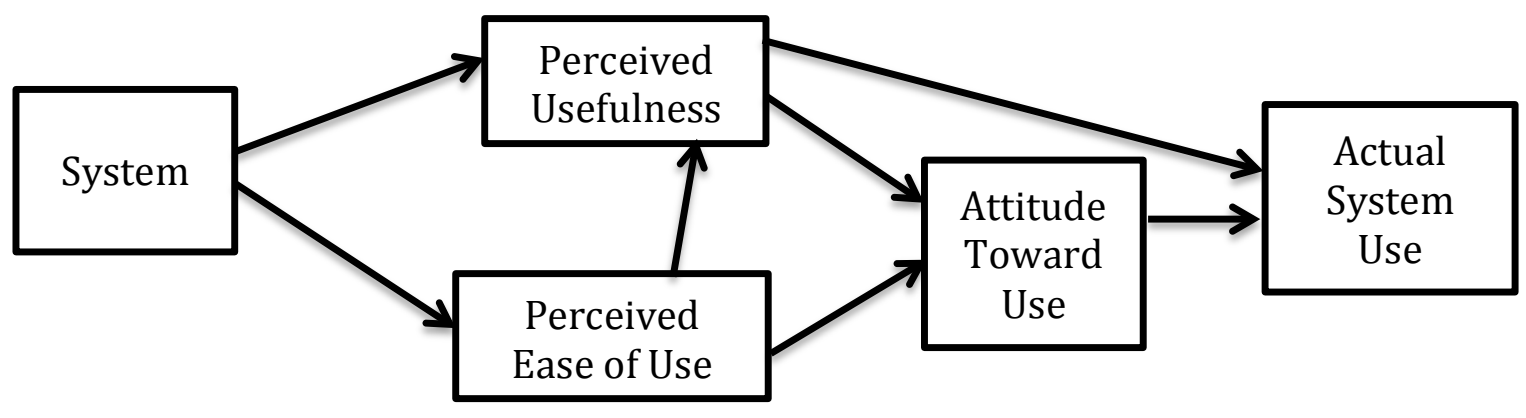

\section{Definition of Terms}

Asynchronous online learning is online learning that does not apply to audio/video communication, but instead relies solely on a text-based, written discussion format for communication (Ward, Peters, Shelley, 2010). 
The Blackboard Learning System (LMS) is technology that uses virtual learning and helps instructors with course management. "It empowers instructors with tools to engage every learner. Motivating them on the devices they rely on. Promoting collaboration and streamlining processes.” (http://www.blackboard.com)

Desire2Learn Incorporated (also known as Desire2Learn or abbreviated as D2L) "Enables both face-to-face and online learning in higher education by promoting communication and collaboration inside or outside the classroom." (http://www.brightspace.com).

Information and Communication Technology (ICT) is the electronic and nonelectronic technologies and infrastructure systems used to create, store, manipulate, retrieve, and communicate or disseminate information (Meadowcroft, 2006; Mejiuni and Obilade, 2006)

Synchronous online learning (SOL) is online learning that applies live audio/video communication to an online class (Ward et al., 2010).

\section{Limitations}

A limitation of the study is that the data collection survey is self-reported so the results may be biased. For example, faculty who are proficient with technology might be more likely to complete the survey than faculty who do not use any technologies or use few technologies. So responses might indicate that faculty use more technologies than they really do. Another limitation and potential source of bias is that participants who do not have access to the Internet are not included in the study because the questionnaires 
for data collection were distributed via email. In addition, data for the number of faculty completing the questionnaire from each university was not collected. Failure to collect data about the number of faculty from each institution may introduce another potential source of bias because ICT use and attitudes toward ICT use may be overrepresented by the larger numbers of faculty representing the eleven universities in this study.

\section{$\underline{\text { Delimitations }}$}

The results from this study are generalizable to the 11 universities represented by faculty who participated in this study. These universities are presented in Table 1 below.

Table 1. Saudi and United States Faculty Participant Institutions

\begin{tabular}{|l|l|}
\hline Saudi Institutions & United States Institutions \\
\hline King Saud University & Minot State University \\
\hline King Khalid University & Montana State University \\
\hline Imam Muhammad Ibn Saud University & Stanford University \\
\hline Umm Al-qura University & University of Michigan \\
\hline Taibah University & Washington State University \\
\hline & Wayne State University \\
\hline
\end{tabular}

Significance of the Study

This research will benefit researchers who are considering the potential use of electronic tools for improving higher education. Results from this study will provide information about the prevalence and use of electronic communication and educational 
technologies in both the United States and Saudi Arabia. These results will serve to inform other Saudi and United States faculty about types of educational technologies that are currently being used to interact with students and to support instruction. Traditionally, Saudi Arabia has been reluctant to endorse the use of online educational technologies as legitimate forms of higher education instruction (Hamdan, 2014). Results from this research, however, may help the Saudi Ministry of Higher Education, Saudi faculty and Saudi University administrators to better understand the use and effectiveness of electronic tools such as Learning Management Systems, I Videos, and Web-Based Conferencing as valid forms of instruction

\section{Summary}

This descriptive study identifies the types of technologies Saudi faculty and United States faculty use to support learning in higher education. Results from this study report the similarities and differences in technology use by Saudi and United States faculty to support learning and interact with students. Results from this study will inform leadership in the Saudi Ministry of Higher Education, as well as United States faculty, about prevalence and perceptions of technology use higher education faculty to support student interactions and learning. 


\title{
CHAPTER TWO
}

\section{REVIEW OF LITERATURE}

\author{
Introduction
}

This chapter presents an overview of the use of electronic tools for instruction in higher education. The concept map presented in Figure 2 below provides a visual outline of the concepts discussed in this review of the literature. Methodology for this main body of research was categorized by research design and data acquisition method in Table 2. The numbers in Table 2 correspond to the number of the research article listed in Table 3.

Figure 2. Literature Review Concept Map

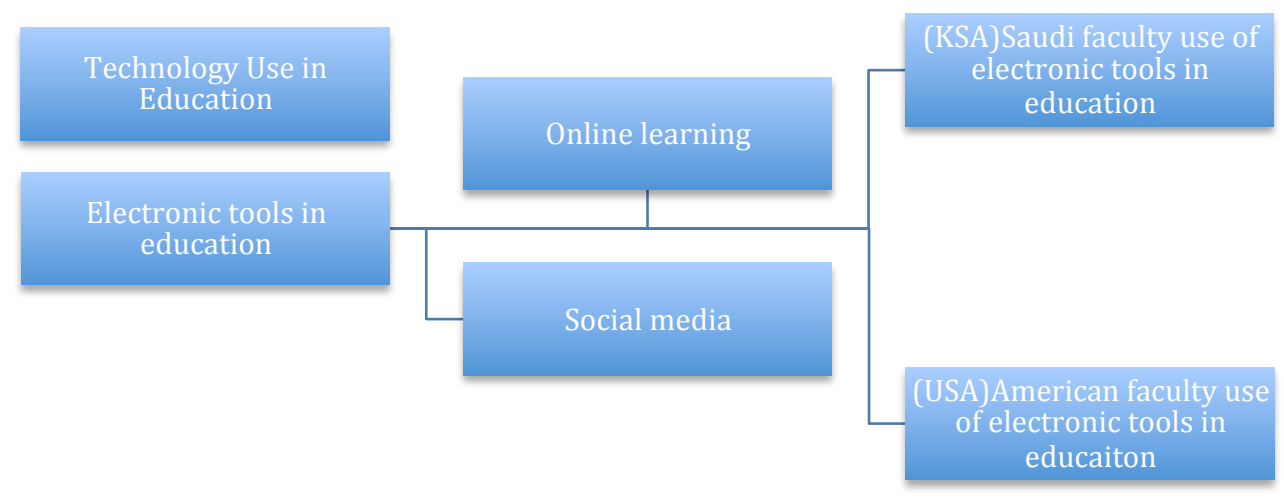


Table 2. Research Methodology

\begin{tabular}{|c|c|c|c|c|c|c|}
\hline \multirow{2}{*}{\begin{tabular}{|l|} 
Research \\
Methodology
\end{tabular}} & \multicolumn{6}{|c|}{ Data Acquisition methods } \\
\hline & Interview & Survey & Ed. Tests & Case Study & Observation & Journals \\
\hline $\begin{array}{l}\text { Literature } \\
\text { Review }\end{array}$ & 2,1 & 3,11 & & & $16,19,28,42$ & $\begin{array}{l}1,17,20,24,30 \\
31,33,38,39 \\
43,45,46,50\end{array}$ \\
\hline Action Research & & 26 & & & & \\
\hline Experimental & & & & & & \\
\hline Correlational & & & & & & 27 \\
\hline $\begin{array}{l}\text { Causal- } \\
\text { comparative } \\
\text { research }\end{array}$ & & $\begin{array}{l}9,10,13,36 \\
47\end{array}$ & & & & \\
\hline $\begin{array}{l}\text { Ethnographic } \\
\text { research }\end{array}$ & 8 & 25 & & & & \\
\hline $\begin{array}{l}\text { Evaluation } \\
\text { Research }\end{array}$ & 23,29 & $\begin{array}{l}2,5,6,7,15, \\
18,22,26,32 \\
35,44,48\end{array}$ & & 49 & $4,34,37$ & 40 \\
\hline
\end{tabular}

Table 3. Literature Reviewed

\begin{tabular}{|l|l|l|}
\hline $\begin{array}{l}\text { Article } \\
\text { Number }\end{array}$ & Article Title & Authors \\
\hline Article 1 & $\begin{array}{l}\text { Motivation and cognitive load in the flipped } \\
\text { classroom: definition, rationale and a call for research }\end{array}$ & $\begin{array}{l}\text { Abeysekera, L., } \\
\text { \& Dawson, P. }\end{array}$ \\
\hline Article 2 & $\begin{array}{l}\text { Investigating Faculty Decisions to Adopt Web 2.0 } \\
\text { Technologies: Theory and Empirical Tests }\end{array}$ & Ajjan, H, \& Hartshorne, R. \\
\hline Article 3 & $\begin{array}{l}\text { E-integration challenges for rectors and deans in } \\
\text { higher education. Computer and Advanced } \\
\text { Technology in Education Conference Proceedings. } \\
\text { ACTA Press. Canada. }\end{array}$ & Al-Jarf, R. \\
\hline Article 4 & $\begin{array}{l}\text { The state of distance education in Saudi Arabia. } \\
\text { Retrieved from } \\
\text { http://elearnmag.acm.org/archive.cfm?aid=1642193 }\end{array}$ & Al-Khalifa \\
\hline
\end{tabular}


Table 3. Continued

\begin{tabular}{|c|c|c|}
\hline Article 5 & $\begin{array}{l}\text { Developing an E-Learning Training Package for } \\
\text { Academic Staff in One University in Saudi Arabia. }\end{array}$ & Al Mulhem, Ahmed \\
\hline Article 6 & Internet Usage by Faculty in Saudi Higher Education. & $\begin{array}{l}\text { Al-Shawi, A., \& } \\
\text { Al-Wabil, A. }\end{array}$ \\
\hline Article 7 & $\begin{array}{l}\text { E-learning in the KSA: A taxonomy of learning } \\
\text { methods in Saudi Arabia }\end{array}$ & Alharbi, A. \\
\hline Article 8 & Saudi Women and E-learning & $\begin{array}{l}\text { Alhareth, Y. McBride, N. } \\
\text { Prior, M.,Leigh, M. \& Flick, } \\
\text { C. }\end{array}$ \\
\hline Article 9 & $\begin{array}{l}\text { Changing course ten years of tracking online } \\
\text { education in the United States. }\end{array}$ & $\begin{array}{l}\text { Allen, I. E., \& Seaman, J. } \\
(2013) .\end{array}$ \\
\hline Article 10 & $\begin{array}{l}\text { Going the Distance: Online Education in the United } \\
\text { States }\end{array}$ & $\begin{array}{l}\text { Allen, E., \& Seamen, J. } \\
(2011) .\end{array}$ \\
\hline Article 11 & $\begin{array}{l}\text { The Perceptions Of Saudi Student On Using Fully } \\
\text { Online Courses At University. }\end{array}$ & Altawil, A \\
\hline Article 12 & $\begin{array}{l}\text { Information and Communication Technologies Used } \\
\text { for Education and Training }\end{array}$ & $\begin{array}{l}\text { Andronie, M. \& } \\
\text { Andronie, M }\end{array}$ \\
\hline Article 13 & $\begin{array}{l}\text { The Seven Principles of Good Practice: A framework } \\
\text { for evaluating on-line teaching. }\end{array}$ & Bangert, A. (2004) \\
\hline Article 14 & $\begin{array}{l}\text { How 'Flipping' the Classroom Can Improve the } \\
\text { Traditional Lecture }\end{array}$ & Berrett, D. \\
\hline Article 15 & The Flipped Classroom: A Survey of the Research & Bishop, J. L. \\
\hline Article 16 & $\begin{array}{l}\text { How social media can and should impact a higher } \\
\text { education. }\end{array}$ & Blankenship, $\mathrm{M} \backslash$ \\
\hline Article 17 & Flipping the classroom & Brame, C. J. \\
\hline Article 18 & $\begin{array}{l}\text { Instructor perceptions of teaching online at Montana } \\
\text { State University }\end{array}$ & Brown, L. \\
\hline Article 19 & $\begin{array}{l}\text { How to Help Teachers Use Technology in the } \\
\text { Classroom. }\end{array}$ & Burns, M. \\
\hline Article 20 & Technology in the classroom: Helpful or Harmful? & Cleaver, S. \\
\hline Article 21 & $\begin{array}{l}\text { Acceptable use of technology in schools: Risks, } \\
\text { policies, and promises. }\end{array}$ & Cramer, M., \& Hayes, G. \\
\hline Article 22 & $\begin{array}{l}\text { Emerging instructional technologies: Exploring the } \\
\text { extent of faculty use of web } 2.0 \text { tools at a Midwestern } \\
\text { community college. }\end{array}$ & Daher, T., \& Lazarevic, B. \\
\hline Article 21 & $\begin{array}{l}\text { Mobile computing devices in higher education: } \\
\text { Student perspectives on learning with cellphones, } \\
\text { smartphones \& social media. }\end{array}$ & Gikas, J. \& Grant, M. M. \\
\hline Article 22 & Evidence on Flipped Classrooms Is Still Coming In. & Goodwin, B. \& Miller K. \\
\hline Article 23 & $\begin{array}{l}\text { The Reciprocal and Correlative Relationship Between } \\
\text { Learning Culture and Online Education: A Case from } \\
\text { Saudi Arabia. }\end{array}$ & Hamdan, A \\
\hline Article 24 & $\begin{array}{l}\text { Faculty Online Technology Adoption. The Role of } \\
\text { Management Support and Organizational Climate }\end{array}$ & $\begin{array}{l}\text { Huang, R., Deggs, D., Jabor } \\
\text { M., Machtmes, K. }\end{array}$ \\
\hline
\end{tabular}




\section{Table 3. Continued}

\begin{tabular}{|c|c|c|}
\hline Article 25 & A study of faculty effort in online teaching & $\begin{array}{l}\text { Hislop, G.W., \& Ellis, } \\
\text { H.J.C. }\end{array}$ \\
\hline Article 26 & $\begin{array}{l}\text { How Technology Trends Have Influenced the } \\
\text { Classroom. }\end{array}$ & Hooker, C. \\
\hline Article 27 & Reflections of Beginning Music Teachers & Krueger, P. J. \\
\hline Article 28 & $\begin{array}{l}\text { Themes and Strategies for Transformative Online } \\
\text { Instruction }\end{array}$ & $\begin{array}{l}\text { Mayes, R., Luebeck, J., } \\
\text { Ku, H. Akarasriworn, C., } \\
\text { \& Korkmaz, O }\end{array}$ \\
\hline Article 29 & $\begin{array}{l}\text { Can Online Learning Reproduce the Full College } \\
\text { Experience? }\end{array}$ & McKeown, K \\
\hline Article 30 & $\begin{array}{l}\text { Teaching, learning, and sharing: How today's higher } \\
\text { education faculty use social media }\end{array}$ & $\begin{array}{l}\text { Moran, M., Seaman, J. and } \\
\text { Tinti-Kane, H. }\end{array}$ \\
\hline Article 31 & Perspectives on distance education and social media. & $\begin{array}{l}\text { Powers, L, Alhussain, R., } \\
\text { Averbeck, C., \& } \\
\text { Warner, A. }\end{array}$ \\
\hline Article 32 & Facebook Passes 1.23 Billion Monthly Active Users & Protalinski, E \\
\hline Article 33 & Email Statistics Report, 2011-2015 & Radicati, S. \\
\hline Article 34 & $\begin{array}{l}\text { Findings on Facebook in higher education: A } \\
\text { comparison of college faculty and student uses and } \\
\text { perceptions of social networking sites. }\end{array}$ & $\begin{array}{l}\text { Roblyer, M.D., McDaniel, } \\
\text { M., Webb, M., Herman, J. } \\
\text { \& Witty, J.V }\end{array}$ \\
\hline Article 35 & The Good Mentor: What It Takes To Be Effective & Rowley, J. \\
\hline Article 36 & Learning Theories: An Educational Perspective & Schunk, D. \\
\hline Article 37 & Connectivism: A Learning Theory for the Digital Age & Siemens, G. \\
\hline Article 38 & $\begin{array}{l}\text { Strategies That Work. One school technology leader's } \\
\text { winning strategies for staff development in technology } \\
\text { integration }\end{array}$ & Smith, Michael \\
\hline Article 39 & Encouraging Teacher Technology Use & Starr, L. \\
\hline Article 40 & $\begin{array}{l}\text { The Flipped Classroom: Turning the Traditional } \\
\text { Classroom on its Head }\end{array}$ & Strayer, J \\
\hline Article 41 & Adoption of Web 2.0 tools in distance education & Usluel, Y \& Mazman, S. \\
\hline Article 42 & $\begin{array}{l}\text { Face to Facebook: Social media and the learning and } \\
\text { teaching potential of symmetrical, synchronous } \\
\text { communication }\end{array}$ & $\begin{array}{l}\text { VanDoorn, G. \& Edlund } \\
\text { A. }\end{array}$ \\
\hline Article 43 & Integrating social media in education & $\begin{array}{l}\text { Vanwynsberghe, } \mathrm{H}, \& \\
\text { Verdegem, } \mathrm{P}\end{array}$ \\
\hline Article 44 & $\begin{array}{l}\text { Interaction in Online Learning Environments: A } \\
\text { Review of the Literature }\end{array}$ & Wanstreet, C. \\
\hline Article 45 & $\begin{array}{l}\text { Student and Faculty Perceptions of the Quality of } \\
\text { Online Learning Experiences. }\end{array}$ & $\begin{array}{l}\text { Ward, M., Peters, G., \& } \\
\text { Shelley, K. }\end{array}$ \\
\hline Article 46 & $\begin{array}{l}\text { Faculty satisfaction in the online environment: An } \\
\text { institutional study. }\end{array}$ & $\begin{array}{l}\text { Wasilik, O., \& Bolliger, D. } \\
\text { U. }\end{array}$ \\
\hline Article 47 & $\begin{array}{l}\text { Making Connections: Higher Education Meets Social } \\
\text { Media }\end{array}$ & Wilson, C D. \\
\hline Article 48 & $\begin{array}{l}\text { Common Barriers to E-Learning Implementation in } \\
\text { Saudi Higher Education Sector: A Review of Literature }\end{array}$ & Al Mulhem, A \\
\hline
\end{tabular}


People today acquire information by a variety of methods_-books, magazines, periodicals, encyclopedias, and the Internet. Access to education was very limited in the past because there was a lack of technology and good transportation. Many people, especially in rural areas, simply lived and worked without ever gaining formal education. However, the United States worked to fix this and educate the American people using the postal service. According to Brown (2013):

The postal service was critical in bringing education to the dispersed masses. The first distance education courses were correspondence courses. Readings, assignments and quizzes were sent out by the educational institution and the student read and performed the assignments and quizzes and returned the materials through the postal service. (p. 7)

Although correspondence education was relatively effective in the United States, it was not a transferrable system. For the rest of the world, including Saudi Arabia, a lack of addresses and a system like the U.S. Postal Service prevented many people from gaining access to this new idea known as education. Largely because of the geographic terrain in Saudi Arabia, early attempts at creating a national postal service were unsuccessful. Saudi Arabia's first post office was not established until 1935 (www.sp.com.sa, n.d.). Because education in Saudi Arabia developed less quickly than in the United States, many people remain illiterate and uneducated due to continued lack of access to schools. Many policymakers have called for improvement of the education system - specifically through the use of technology — to provide greater opportunities to access education regardless of geographical location or resource limitations. 


\section{Technology Use in Education}

New technology has been transforming the global, educational landscape, but Saudi schools are still in the early stages of utilizing technology as an educational tool. The earliest applications have not been extremely successful: "The first used technologies, radio, $\mathrm{TV}$, one way video conferences, e-mail, discussion forums etc. provided a communication between users, however, they were [lacking] effective interaction and collaboration" (Usluel and Mazman, 2009). However, as electronic communication tools like social media, D2L, and Blackboard have developed and improved, the future begins to look more promising. Many Saudi schools have started to improve their teaching and communication systems using electronic tools to engage students and save time. This struggle is not unique to Saudi professors, however. As Hooker (2014) writes,

Teachers all over America are faced with this challenge of keeping students engaged in the classroom [...] How to act and adjust schools today is the next step in making the classroom of today ready for tomorrow [...] Technology would seem to be the panacea for solving all of these issues when it comes to engaging the digital brain [...] Until the pedagogy and purpose align with this new world, we are all left fighting a battle rather than embracing it. (n.p.)

Even for American professors, the struggle continues of how to engage students with technology in a meaningful fashion. Some of this results from a lack of resources and time to find new ways to connect the two. However, many teachers remain uncertain and reluctant about their abilities to use technology, and are often unaware of the resources that are available. Although efforts improve, some teachers still reluctant to use technology because of a lack of time, a lack of resources, or a lack of confidence in their ability to use the available technology (Starr, 2012). 
If teachers lack the confidence and ability to incorporate technology, it seems unlikely that they will train or mentor other teachers to effectively use technology (Bingimlas, 2004). The problem is exacerbated by the lack of effort by anyone to be a vanguard and make efforts to better incorporate technology. Some teachers are reluctant because they view technology as a distraction; however, if technology is not redirected for educational purposes, it will only continue to grow as a distraction. Now more than ever, it is necessary to implement a program that educates teachers in the use of electronic tools in their classrooms in order to help them better communicate and engage with students, as well as utilize and access the significant amount of information available to help them grow and enhance their curriculums. As Michael Smith (2014) notes,

Technology plays a critical role in allowing teachers to focus on studentcentered instruction. That's why effective staff development can go a long way toward helping us retool our schools and turn them into learning environments that will truly prepare a workforce for the 21 st century. (n.p.) (www.scholastic.com)

Professors must have access to and knowledge of such resources if they hope to effectively lead, facilitate, and teach online courses. It is very important for teachers to learn how to use and apply these new technologies in classrooms to engage students. Teachers must be trained in fundamental technological skills, including using a computer and projector, because using such technologies has the potential to not only be very helpful to them, but can also create a more engaging environment for students who are generally very interested in technology, whether it be a television, tablet, or a cellphone (Shadiya, 2011). 
In order to achieve goals like this, teachers should attend to all aspects of education because it is an integrative process. I think vision, leadership and budget management are necessary to integrate new technology in the classroom. Teachers should draw clear future strategies to provide new technology in schools because any work without planning produces negative results. They should be able to suggest devices, software, and programs for new teachers, and be able to answer any questions, find proper technology, and give them opportunities to take courses about technology use. They should also learn about computer use and the many programs available to assist students with improving skills like reading, research, and critical thinking. However, "If teachers can't use technology a certain way given their physical or demographic constraints, technology instructors need to know so they can better support teachers with implementation" (Burns, 2010).

\section{Issues Related to Technology Integration in Higher Education}

For many professors, the problem is that they lack the necessary information and skills with technology because the changes took place when they had already developed ideas and methods around curriculum and instruction practices. As Smith (2014) explains,

When it comes to professional development for technology integration, the issue is much the same for veterans as it is for new teachers. New teachers may have a better handle on general computer use, but most colleges of education are still preparing future teachers for an educational system that existed in the distant past. (n.p)

The issue, then, lies not in the technology or the education system, but instead in how the two remain two very separate entities that seem to alienate one another. Many of 
these teachers still have stronger feelings about the negative effects of technology, and therefore find it difficult to see the potential benefits. In order to change this way of thinking, it is necessary to help them see the positive side of technology so that they can incorporate it with their existing wisdom about teaching.

Despite the challenges, incorporating technology into education still has proven benefits, especially when it comes to personalized learning. For example, an instructor may restructure a lecture into a group activity, having students conduct online research to boost their understanding. With such a vast reference tool, the students might pose questions that no one in the class, not even the teacher himself, can answer. Many teachers and schools choose to avoid this situation by discouraging the use of computers in a well-organized lesson. Their latest shipment of Smartboards, ELMOs, or iPads stays locked in a closet as they struggle to find the time to effectively incorporate them into the curriculum plan (Cleaver, 2014).

While for some faculty the issue is reluctance, for others the issue is time. According to Al Mulhem "Many Saudi studies agree with the findings of the international studies find that academic staffs do not have sufficient time for training and preparation of e-learning" (p.833). Training requires time and resources that many teachers already lack due to the overwhelming amount of time and energy they put into their work. However, the benefits of technology use provide opportunities to save time and energy by speeding up processes for accessing information and communicating. 


\section{Technology Training}

Additionally, many students frequently use iPads and cellphones as a large part of their everyday life. Listening to music, word processing, watching movies, and reading internet articles are all happening at once for students. If teachers do not know how to use these technologies, students may begin to question their knowledge. Therefore, training to integrate technology in the classroom is very important because illiteracy with technology translates into illiteracy in this day and age. Because the numbers of users of technology increases every day the need is more and more pressing all the time. It is evident that schools need to train teachers in technology integration. However, the implementation of such training often proves difficult. As mentioned above, the time and resources needed to accomplish such a program often remain sparse or nonexistent.

While many teachers may lack experience with technology, they may have a vast experience with methods, theories, and approaches that improve learning environment for themselves and students. If given the opportunity to integrate such ideas with their own understanding of technology and its potential uses in classrooms, professors may find ways to better unify education and technology. If given encouragement, a support system, and an amount of freedom, they have ideas and opportunities that a previous generation might entirely miss. Given an appropriate amount of feedback and support, the next generation of professors has an opportunity to rethink and redevelop learning environments in new ways. While most teachers have basic skills with a computer and projector, this often marks the end of technological implementation in the classroom. 
However, further training with other software and hardware is necessary (Al Mulhem, 2013).

Internet access, rather by stationary or mobile device, offers students access to a diverse and expansive collection of ideas and information, that them to be able to see, access, think about, and learn far more than what was once thought possible. When faculty use traditional lecture approaches for instruction that do not incorporate instructional technologies designed to increase engagement, students may feel bored and may not achieve intended learning goals. Schools are still slow to adopt technologies that are well-suited for improving instruction, continuing to focus on outdated, lecture-style methods. Cramer and Hayes (2010) suggest "The next step toward a truly connected youth is bridging the gap between in-school and out-of-school technology use, both in policy and practice" (p. 43). Bridging this gap means helping students see the technology they use as something beneficial, not simply something entertainment oriented. Instead of simply gathering information via the technology, they can use available technologies to enhance their effectiveness as student and learner. The goal in this case is not information transfer, but instead the ability to solve problems through critical thinking. When used properly, technology has the potential to be another tool in a teacher's arsenal that aids them in fostering critical thinking within their classroom.

\section{Integrating Technology in Education}

Maximizing the use of educational technologies requires thoughtful integration of technology into the curriculum. According to Edutopia (2007), 
Technology integration is the use of technology resources - computers, mobile devices like smartphones and tablets, digital cameras, social media platforms and networks, software applications, the Internet, etc.-in daily classroom practices, and in the management of a school. Successful technology integration is achieved when the use of technology is: Routine and transparent; Accessible and readily available for the task at hand; Supporting the curricular goals, and helping the students to effectively reach their goals (n.p.).

Considering these three ideas is essential in achieving the "how" of technological integration. The notion of "Routine and Transparent" use provides the foundation for technology integration, that is, students become familiar with the technology through routine use, and aware of its purposes through clear explanation of the intended uses and purposes. In order for technology to be useful to students, technology must be readily accessible. While most people in the United States own a computer, computer and Internet availability is sparse in Saudi Arabia, especially rural areas. Schools that integrate technology must do more than just explain the benefits and used, they must make it accessible. Finally, technology for the sake of technology is not helpful in education. Technology use must support instructors' efforts to help students achieve educational goals. Siemens (2004) writes that,

Over the last twenty years, technology has reorganized how we live, how we communicate, and how we learn. Learning needs and theories that describe learning principles and processes, should be reflective of underlying social environments (n.p).

Siemens focuses on the idea of "connectivism," which he defines as, "the integration of principles explored by chaos, network, and complexity and self-organization theories" (n.p.). This idea is important to the integration of technology because the key to technology in education is effective integration. 
The Importance of Technology Integration

for Education in Saudi Arabia

Electronic tools assist in solving many problems that professors and students face with regards to communication and learning. There are significant differences between Saudi education and American education because the Saudi culture refuses to teach females and males together, so Saudi schools must provide separate classrooms for males and females. Many universities lack female professors in the majority majors of that are offered, and use male faculty to teach classes for males; females are excluded. It is obvious how the current gender-divided system prevents women from having better educational opportunities: women are unable to access education due to a lack of female professors, whose numbers are so low due to a lack of access to adequate education for women. In addition, “[T]he only Higher Education institutes exclusively for women are located in the capital Riyadh and the second city Jeddah which demonstrates the difference between the urban elite and the rural population who have less opportunity" (Alhareth, McBride, Prior, Leigh \& Flick, 2011). Electronic communication would offer a solution for delivering education outside of the major cities. If women were able to attend classes online, they would not have to worry about lacking professors, travelling/moving to urban centers, and cultural limitations.

Recent studies indicate that the current Saudi education system could benefit from new technology, and save resources while increasing services. Alharbi (2013) notes that:

Over the last 10 years, there has been an increased emphasis on exploring different kinds of delivery methods and technologies in order to expand opportunities for course delivery to students across the KSA. The tertiary education system in the KSA is, like all domains of Saudi Arabian public 
life, based on the complete separation of students and staff by gender. Therefore, educational institutions have to provide separate buildings and staff for their male and female students. This puts a considerable strain on available resources and accommodation. E-learning and distance learning technologies open up a new mode of education delivery for many Saudi educational institutions, which allows students to utilize a learning option which may better suit their learning style (p. 5).

One of the major differences between the United States and Saudi Arabia with regard to distance delivery of education via the Internet is that the Saudi educational system is controlled by The Ministry of Education. The Saudi Ministry of Education has been slow to recognize the potential of online learning and the use of other electronic tools to increase educational access. On the other hand, the American educational and cultural systems operate in an entirely different fashion. In the United States, education is highly decentralized and instructional delivery is not controlled by the federal government (Abdulmohsin, 2012). In addition, men and women in the United States are not culturally prevented from attending public schools and universities together.

The main reason for widespread use of electronic communication technologies in the USA, such as those used for online learning, is due to the relative ease with which teachers and students alike can access online courses and other online learning resources. According to Averbeck, Alhussain, Ruqaya, \&Andre (2012), massive open online courses (MOOCs) allow content to be delivered and accessed for free. However, more importantly, as compared to the traditional classroom model, online courses are not dependent on time and space. Students can study asynchronously on their own or cooperatively by accessing content when it is convenient and appropriate to their learning needs. 
Hislop and Ellis (2004) investigated the time it took faculty to teach online courses as compared to comparable traditional face-to-face courses. Results from their study revealed that faculty spent 737 hours teaching the online sections as compared to 814 hours for the same course offered face-to-face. Despite the fact that the numbers suggest online courses take less time, faculty perceptions are that online courses take considerably more time to teach. Although this research is somewhat contradictory to findings from other studies, it suggests that faculty perceptions that online instruction is much more time intensive as compared to traditional face-to-face modes of instruction may be mistaken.

\section{Recent Innovation}

Engagement is important to achieve education goals today, so technology supports engagement techniques such as the flipped classroom, which utilizes student motivation, both intrinsically and extrinsically, to create a more successful educational outcome (Strayer, 2011). See Figure 3 illustrates Strayer's concept. Indeed, motivation is very important for students to attend their classes and become successful in their studies, and can be utilized to increase differentiation, offer encouragement, and increase learning. According to Berrett (2012), “Adding to these forces is economic reality. Strained budgets make it difficult for colleges to decrease class sizes and create more seminars in which low student-to-professor ratios allow a high degree of personal attention” (n.p.). For example, many classes at Imam University consist of more than 100 students, creating difficulties in classroom management and organization. Professors spend a lot of 
time taking student attendance and disciplining the class, time that could be better served teaching and learning. Implementation of new, interactive methods could engage students, help faculty save time, and help provide more information that students need. For example, the use of technology to create a flipped classroom learning environment may serve to reduce the difficulties that Saudi faculty face in higher education at universities such as Imam University.

Figure 3. The Flipped Classroom Model.

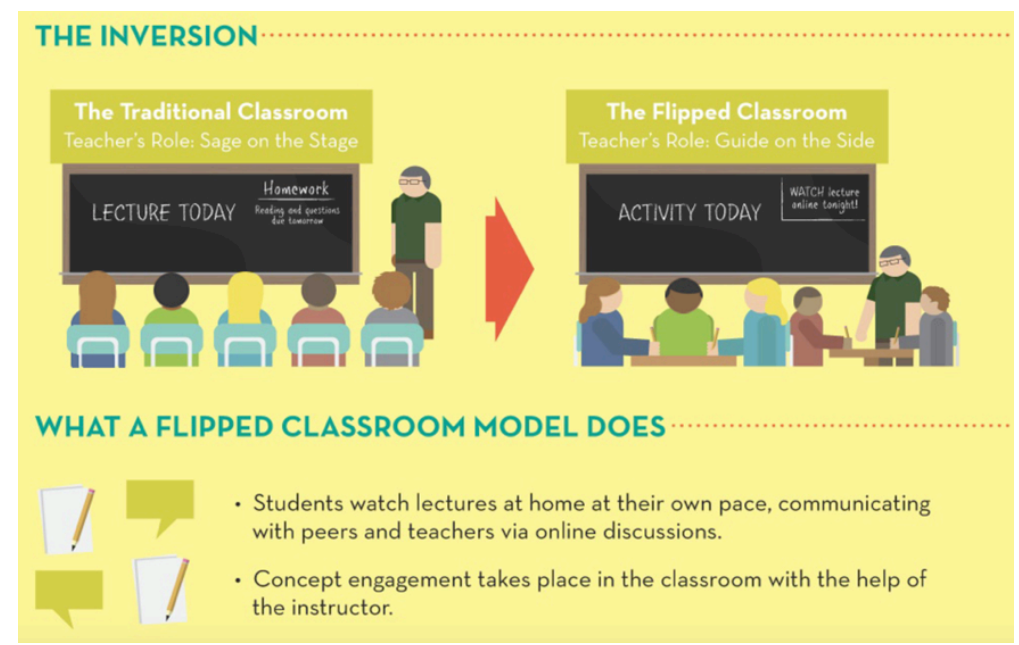

Flipped classrooms are an example of a modern instruction method. According to Lakmal and Phillip (2014) the flipped classroom approach has been implemented since about 2011. A flipped classroom model is one where "students gain first exposure to new material outside of class, usually via reading or lecture videos, and then use class time to do the harder work of assimilating that knowledge, perhaps through problem-solving, discussion, or debates" (Brame, 2013, para. 1). The classroom format provides students 
with a more in-depth understanding of concepts and information, as well as saves time for the professor, and creates a more meaningful in-class experience for the student. Students typically are doing the lower levels of cognitive work (gaining knowledge and comprehension) outside of class, and focusing on the higher forms of cognitive work (application, analysis, synthesis, and/or evaluation) in class, where they have the support of their peers and instructor" (Brame, 2013, para. 1). Flipped classroom instructional approaches could help professors assist students in collaboration, discussion, problem solving, and assignments.

Flipped classrooms are likely to assist students by using and generating greater levels of intrinsic motivation. According to Abeysekera and Dawson (2014) the flipped classroom approach is likely to satisfy students' needs to feel competent and in turn increase intrinsic motivation and value. According to Bryan and Kirsten (2013),

Some teachers are now turning this model on its head, creating flipped or inverted classrooms in which they record lectures and post them online. Students watch the lectures at home, where they can speed through content they already understand or stop and review content they missed the first time the teacher discussed it (and might have been too embarrassed to ask their teacher to repeat in class). Online lectures can also easily incorporate visual representations, such as interactive graphs, videos, or photos of important historical events (p. 78).

The advantages of flipped classrooms are that they give professors a chance to better manage and assist students by answering questions, explaining concepts, solving problems, and producing successfully completed homework regardless of the number of students in the class. Teachers that use inverted classrooms are more likely to better understand and respond to students' emotional and learning needs (Bryan and Kirsten, 
2013). A flipped classroom can be created in many ways to suit a teacher's personality and teaching style, as well as the personality and learning conditions of their class.

Learning environments created by the flipped classroom are also likely to increase extrinsic motivation to engage in learning activities by satisfy students' need for autonomy enhancing their levels of extrinsic motivation (Abeysekera \& Dawson, 2014). When students are given these opportunities, they are more likely to be motivated about the things they are learning. While specific material must be covered in any given class, providing students with an opportunity to teach some of that information, or deciding how it is shared and thought about, allows them to more fully engage with the material. This also caters to varied learning styles; some students might function better as leaders, while others function better creatively without writing or speaking. Brame (2012) cites the following example:

To make their course more compatible with their students' varied learning styles, they designed an inverted classroom in which they provided students with a variety of tools to gain first exposure to material outside of class: textbook readings, lecture videos, Powerpoint presentations with voice-over, and printable Powerpoint slides. To help ensure student preparation for class, students were expected to complete worksheets that were periodically but randomly collected and graded. Class time was then spent on activities that encouraged students to process and apply economics principles, ranging from mini-lectures in response to student questions to economic experiments to small group discussions of application problems. Both student and instructor response to the approach was positive, with instructors noting that students appeared more motivated than when the course was taught in a traditional format (p. 2-3.) 


\section{Electronic Tools for Communication}

\section{$\underline{\text { Social Media }}$}

In the midst of countless technological advances, social media has changed the technological landscape in numerous ways and is reshaping ideas, tendencies, and even beliefs. As social media has developed, people have the ability to share information, ideas, and media with great ease. To an extent, the world has shrunk due to the presence of social media in the world. To give one example of the prevalence of social media in the world, Facebook "has now passed 1.23 billion monthly active users" (Protalinski, 2014). That means approximately 1 in every 7 people in the world uses Facebook. As it becomes more prevalent as a part of life, social media has inevitably found its way into the modern classroom. According to Vanwynsberghe, Hadewijch, Verdegem, \& Pieter (2013):

In today's networked society students are new media users, $[\ldots]$ hence the relevance in curricula to include social media literacy [...] Given the combination of the social network revolution, the [I]nternet revolution, and the cell phone revolution, it becomes important to investigate how people are using social media and how to integrate social media literacy in education" (p. 3).

It has been difficult to determine whether or not social media is actually helpful in the classroom because, in many cases, widespread application remains fairly limited. The results in Figure 4, below, from the research of Moran, Seamen, and Tinti-Kane (2011) representing "faculty class use of social media by site," reveal some of my rationale. 
Figure 4. Faculty Class Use of Social Media by Site.

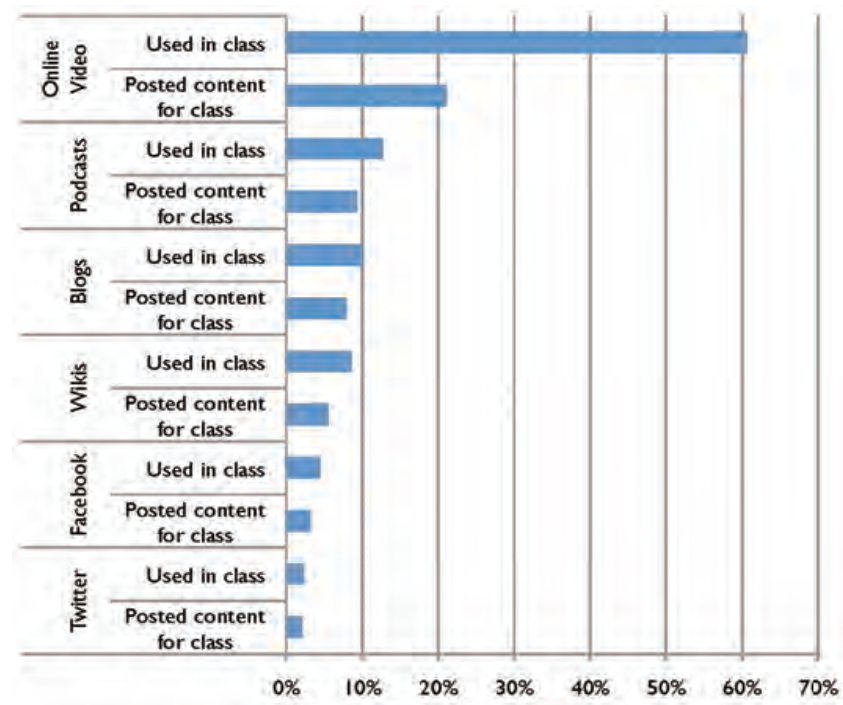

As pointed out earlier, social media use is widespread and growing every day.

While many acknowledge the benefits of being able to easily communicate with a large number of people, teachers do not take advantage of this opportunity. The only area where a large number of teachers utilize some form of social media is online video, which functions more as an educating tool rather than a communication tool. While the benefits of more communication oriented social media might prove difficult to discover, opportunities exist. A good example of social media being helpful in a classroom comes from VanDoorn and Eklund (2103):

In the broader context of a push toward flexible learning, Facebook as a learning tool and a learning environment seems to offer a win-win. It allows institutions to offer dual-mode courses across on- and off-campus cohorts, and develop learning communities that facilitate positive learning outcomes (p. 1).

Much of what makes social media beneficial for classes is its ability to keep students and teachers connected outside and beyond the classroom. 
Gikas and Grant (2013), give the example of a group of students at Coastal College:

The students described their ability to collect data and interact with content as they immediately came across it in their daily lives. The students were creating a virtual history blog [...] they were able to post content immediately to the blog wherever they were during the day" ( $p$. 22).

The ease and speed of access offer students the opportunity to engage immediately with information wherever they are, which keeps them engaged with material beyond the classroom, and in a way that forces them to be more aware of the material they are learning. The benefits of this are obvious, including better information retention and understanding of real world applications. Another example given focuses on the use of Twitter: The students on their own found the continued interactions valuable to their learning. Interacting with the theorists over Twitter created a connection and a level of excitement for the student that reading and discussing the articles alone did not." (p. 22). For these students, social media functioned as a way to meet them where they already are. The presence of information pertinent to their learning on Twitter encouraged them to engage with the material in a platform that is interesting and comfortable to them, rather than an environment that often carries negative associations.

Many schools worldwide are now looking for ways to utilize social media as part of their communication and classroom interactions. Ideally, these efforts would increase student interaction and engagement. Blankenship (2011) surveyed 1,000 college and university students and found that more than $80 \%$ use social media applications. Interestingly, this same survey revealed that older faculty (those with 20 or more years 
experience) used social media at almost the same level as their younger peers. Although, this research is somewhat dated, it provides a waypoint for understanding the ubiquitous use of social media today by both students and faculty.

Other evidence to support the prevalent use of social media from Protalinski's (2014) research found that Facebook averages a 22\% increase in users each year. Another example showing this continued growth is email: "The number of worldwide email accounts is expected to increase from an installed base of 3.1 billion in 2011 to nearly 4.1 billion by year-end 2015 . This represents an average annual growth rate of $7 \%$ over the next four years" (Hoang, 2011).

The use of social media programs such as Skype or Google Hangouts to create opportunities for distance learning is common in classrooms across the United States. Research by Ajjan \& Hartshorne (2008) suggests that the use social of social media applications provide an important educational tool for supporting higher education learning. For example there research reports that:

Many respondents acknowledged pedagogical benefits of Web 2.0 applications in higher education. More specifically, blogs were viewed as the most useful Web 2.0 application in terms of improving student learning (47\%), increasing student-faculty interactions (46\%), improving student writing (52\%), improving student writing (41\%) and ease of integration $(46 \%)$. In terms of increasing student-student interactions, social networks were viewed as being the most beneficial (56\%). Social networks were also viewed as useful tools for improving student satisfaction in courses (32\%). For the most part, wikis were viewed as also having significant potential to improve student learning $(42 \%)$, increasing student-faculty $(23 \%)$ and student-student interactions $(20 \%)$, improving student satisfaction with courses (22\%), improving student writing (29\%), and ease of integration (38\%) (p. 78-79). 
Online Learning

The gap between the use of traditional face-to-face courses and online courses continues to shrink. Wanstreet (2006) suggests that there are few difference between a face-to-face and online learning environments. She maintains that constructivist online learning environments are able to replicate the same type of instructor-learner interactions, learner-to-learner interactions and learner interactions with course content. Research by Androni (2014) and in particular has shown a continued upward increase in the number of students enrolling in online courses since 2006. As a result there has been a marked increase in the number of students registering for online courses as compared to traditional, face-to-face courses (p. 380). Online courses function to improve writing, critical thinking, and dialogue in ways that many face-to-face classrooms do not. For students who are often shy and remain quiet while the more outgoing and extroverted students drive the conversation, face-to-face settings are difficult to feel comfortable and function well in. Online discussion board allows them the freedom to speak openly without literally speaking in front of a group of their peers. Other times, it is simply too difficult for everyone to participate in large classrooms. Mihai and Maria Andronie (2014) note:

Technological innovation has fundamentally changed the way in which modern education is conducted, leading to an unprecedented development of distance education based on e-Learning. In this context, the only limits that exist on accessing education are those imposed by access to technology and by the availability of learning resources at the place where the persons interested to learn are, at the time they have available to learn (p. 379). 
A study conducted by Allen and Seaman (2013) discusses the growth and transformation of online learning in the United States for the past ten years. Their research, found that since 2002 , online course offerings by colleges and universities have increased by seventy percent. This finding indicates that online learning has seen steady growth in its overall effectiveness as a means of education. As online instructional methods and learning management systems improve, synchronous interactive online instruction (SIOI) and computer mediated communication (CMC), as well as the concept of hybrid classrooms are likely to be becoming a favorable and even equal alternative.

Ward, Peters, \& Shelley (2010) found Synchronous Interactive Online Instruction (SIOI), to be an effective method of online learning. SIOI is different from both asynchronous online instruction and face-to-face instruction because it incorporates a two way audio/video component. Ward et al. (2010) further found in their study of SIOI that $86 \%$ of the professors agreed or strongly agreed that social interaction was a meaningful and productive process and that SIOI facilitated these interactions within an online educational context. Their research also suggests that a "quality" or "good" experience depends heavily on ease of use with the technology, as well as proficiency and preparedness on the part of the professor. An ongoing presence in discussions, as well as clearly outlined expectations, help students understand their role and required part in driving the class (Garrison, Anderson \& Archer, 2001).

When students were asked about the effectiveness of SIOI, they noted that the effectiveness of the live synchronous classroom was more dependent on instructor facilitation rather than course design (Ward et al., 2010). Ward et al's (2010) research 
further found that student evaluations for courses using the SIOI approach were positive. The most interesting and compelling evidence revealed in this study emerged in these student assessments. On a scale of 1 to 5, 1 being the lowest and 5 being the highest, the mean given by the students for their overall experience was a 4.24 (p. 69). Students specifically identified the quality and amount of content learned, encouraging studentfaculty contact, and encouraging cooperation among students as positive attributes of SIOI courses.

Although researchers such as Andrioni (2014) and Allen and Seaman (2014) have documented an increase in online course offerings and enrollments, from 2011 to 2012 there was a marked drop in students' positive perceptions of online learning. During that time period 32.4 percent of students described online learning as "inferior" (Allen and Seaman, 2013). Online learning is a relatively new instruction format and in many ways is still finding its niche in the academic world. McKeown (2012) disputes criticisms on online learning and suggests that the online experience effectively replicates, matches, or improves upon traditional face-to-face course offerings. She describes what she calls "evidence" that "disputes much of that criticism." She claims that the most compelling evidence surrounds the academic portion, though she admits that "some majors are more easily adapted to the online environment than others. In particular, McKeown cites the study of online coursework conducted by United States Department of Education (2010) that suggests that students performed modestly better, on average, than those learning the same material in face-to-face learning environments. 
Other advantages of online learning cited by McKeon (2010) included flexibility with respect to learning, increased student interaction with a shift away from lectures, and better interactions with professors and other professionals in the field. The SIOI classroom and other hybrid formats are models for increasing effectiveness of the online classroom. A compromise between the online and face-to-face classroom is hybrid delivering. The term "hybrid" here suggests a mixed learning experience with some online and some face-to-face meetings. Research generally suggests that a hybrid approach is the most effective learning environment for students (U.S. Department of Education, 2010). However, the hybrid model works best for students enrolled in online and face-to-face classes at a single university; for learners at a distance or exclusively online students it becomes more problematic. Online learning and its various forms will continue play a large role in providing educational opportunities at colleges and universities regardless of their strengths and limitations.

\section{Saudi Faculty Use of Technology in Higher Education}

The adoption of technology in education has been much slower in Saudi Arabia than in the United States. As adoption increases in the US and remains stagnant or slow in Saudi Arabia, a gap is perpetuated where educational opportunities remain inconsistent. Aljabre (2012) describes this as "the digital divide," stating, "[T[he digital divide continues to haunt the world on a global level, separating the developing from the developed and on the national level dividing the haves from the have nots" (p. 133). For Saudi Arabia, the problems are exaggerated because of extremely remote areas with 
limited internet access, cultural barriers, and a growing number students in urban centers that universities are unable to adequately accommodate. Troudi (2009) notes,

One of the major challenges encountered in Saudi higher education is to provide college education to the rapidly growing student population in the country. The capacity of universities and colleges in Saudi Arabia is limited [...] To tackle this problem, the Ministry of Higher Education endeavours to integrate web-based instruction with traditional instruction in universities (p.49).

A large part of the problem is a lack of resources and access for students. The problem is not necessarily internet access; internet access and use has grown significantly in recent years in Saudi Arabia. Troudi (2009) continues,

Internet access has been available to the public in Saudi Arabia since 1999. In December 2000 there were approximately 200,000 Internet users in Saudi Arabia, and by 2005 this number had grown to 2.54 million, making the growth 1170\% (Communications and Information Technology Commission 2007)" (p. 51).

However, while an increase in Internet use shows positive growth in technology adoption and acceptance, access to online learning has actually decreased. "The number of education institutes offering e-learning has decreased since 2007 , from $24 \%$ to $15 \%$ in 2008. However, the majority (84\%) have purchased/acquired the e-learning system/platform" (p.17).

In Saudi Arabia, early investigations of Internet adoption and diffusion in academia, specifically higher education, have demonstrated that faculty members are in the early stages of adoption[...] More recent studies have reported similar patterns and consistently reported "low adoption rates" (Alshawi and Alwabil, 2013). For example, research by Alshawi \& Alwabil (2013) suggests that Saudi use of technology differs based on the major of expertise. Those working in technologically focused majors spent 
more time with electronic tools, while other majors spent less time with these tools. In addition to slow adoption of Internet use as a way to communicate, Saudi Arabia faces other challenges around the use of technology for communication and instruction. Alhareth et al., (2011), suggest that the major barrier to e-learning in Saudi Arabia relates to cultural beliefs and the nature of the education system. One major feature of this society is the dichotomy that exists between the adoption of modern technology and the preservation of beliefs and religious values. The importance of preserving traditional religious values is a distinction that clearly differentiates Internet use in Saudi Arabia versus the United States. By 2002, 59\% of people in the U.S. were using the Internet as compared to just 38.1\% in Saudi Arabia by 2008 (Altawil, 2012). Even among students in Saudi Arabia, a division exists around the perceived benefits that online learning would have for Saudi Arabians. For example, in research conducted by Altawil, 2012), $44.3 \%$ of Saudi students felt that it would not be difficult to offer online learning in Saudi universities while $37.8 \%$ felt it would be very difficult for Saudi universities to offer online courses.

In the last few years Saudi Arabia has been working toward improving higher education by incorporating more technology. For example, in 2011, the Ministry of Education established the Electronic University that exclusively used electronic tools, such as the Blackboard software, to teach and communicate with students (http://jisr.seu.edu.sa). Creation of this university is an effort by the Ministry of Education to work towards greater acceptance and adoption of electronic tools as a means of improving classroom environments, curriculum, and education as a whole. However, a 
major limitation and barrier to widespread acceptance of electronic tools lies in the attitudes of professors towards their value for supporting instruction. Research studies indicate a clear relationship between use of technology and instructor attitudes, as Al Mulhem (2013) found in his research on 24 female students from several Saudi universities when asked about their attitudes towards the use of electronic tools like the Internet for instruction. Results from his study found that although the majority of the female instructors have positive attitudes towards the Internet, their use of the Internet for instruction is likely to be impacted by the subject area they teach. For example, the majority of the Saudi female science faculty perceived the Internet positively. However, the relationship was not entirely straightforward. While all faculty reported positive attitudes toward the use of the Internet, those who did not use the Internet also reported positive attitudes. For faculty teaching in religious studies, those who do not use the Internet have clearly negative attitudes toward Internet use; however, those faculty who use the Internet have mixed perceptions with some indicating positive perceptions of the Internet while others perceive the Internet negatively. These perceptions clearly contribute the divide that exists between faculty who teach different content and between men and women faculty. Faculty who have mixed perceptions about the benefits of using the Internet are influenced by websites that contain offensive or inappropriate material. While there are obvious benefits for religion classes, such as looking at various translations of a text or exploring the history of religion and the various leaders and influences, these professors remain skeptical. The use of the Internet for instruction in this case is clearly based on unique individual attitudes influenced by the discipline they 
teach. Nevertheless, there are opportunities within all subjects to incorporate electronic tools to enhance greater communication between students and faculty and to support instruction.

Saudi faculty members lack the experience to use electronic tools in education because they do not have adequate training with the technology. For example, Al Jarf (2007) reported that interviews with Saudi university vice-presidents, college deans, vice deans and department heads show that using online courses is negatively influenced by the faculty's lack of training in online instruction. These Another study conducted by Amany Al-Shawi and Areej Al-Wabil (2007) revealed that ultimately professors were simply unaware of many of the tools available, and instead continued using those programs already comfortable to them-including e-mail and basic Microsoft Office applications.

In addition to the negative attitudes towards and lack of training with electronic tools, lack of time also influences faculty use of technology. Findings from Ahmed Al Muhem (2013), a study of Saudi female faculty, found that 53\% cited lack of release time as a factor that strongly influenced their decisions about using online instruction. Taking time to train and understand new concepts and tools is difficult for professors who are often already overwhelmed by the amount of work they have. Many Saudi professors work less during the summer and might be more likely to participate in training opportunities that would support their use of the Internet and other electronic tools to support student learning.

A final barrier for Saudi faculty is a lack of technical support. Research by Al-Jarf 
(2007) found that the technological infrastructure at Saudi universities cannot accommodate all the students and faculty. Many departments do not have computer labs and when they are available, they are not equipped with sufficient numbers of computers, software or Internet connections. Computers are often in disrepair and the network is very slow due to band with limitations. A combination of slow network speeds and slow or limited response to technical problems in addition to a lack of resources creates a sense of uncertainty that may cause Saudi faculty to shy away from the use of the Internet and other associated technologies to enhance their instruction. While educational facilities grow, expand, and develop across Saudi Arabia, technology continues to lag behind. Al Shaer (2007) writes, "Achieving excellence in the teaching and learning processes requires the use of information and communication technology (ICT) inside and outside the school environment, making it a fundamental element in the performance of the school, its administrative and teaching staff, and students" (p.7). Without proper support, whether for resources within educational environments or people with adequate knowledge to train professors and students to use technology for the learning, the problems will only be exacerbated rather than solved. The potential benefits of technology are numerous, but limited acceptance and access prevent Saudi professors, faculty, and students from experiencing these advantages. 


\section{United States Faculty Use of Technology in Higher Education}

Use of electronic communication became widespread in U.S. universities, so much so that more than 6.1 million students were taking at least one online course during the fall 2010 term. That marks an increase of 560,000 students over the number reported the previous year, or thirty-one percent of all higher education students take at least one course online during their time as a student. The growth in online enrollments at United States colleges and universities is represented in Figure 5 from Allen and Seaman (2011) below.

Figure 5. Online Enrollments in United States Colleges and Universities, 2002 to 2010.

\begin{tabular}{|c|c|c|c|c|c|c|}
\hline & $\begin{array}{c}\text { Total } \\
\text { Enrollment }\end{array}$ & $\begin{array}{c}\text { Annual } \\
\text { Growth } \\
\text { Rate Total } \\
\text { Enrollment }\end{array}$ & $\begin{array}{l}\text { Students } \\
\text { Taking at } \\
\text { Least One } \\
\text { Online } \\
\text { Course }\end{array}$ & $\begin{array}{c}\text { Online } \\
\text { Enrollment } \\
\text { Increase over } \\
\text { Previous Year }\end{array}$ & $\begin{array}{c}\text { Annual } \\
\text { Growth } \\
\text { Rate } \\
\text { Online } \\
\text { Enrollment }\end{array}$ & $\begin{array}{c}\text { Online } \\
\text { Enrollment as } \\
\text { a Percent of } \\
\text { Total } \\
\text { Enrollment }\end{array}$ \\
\hline Fall 2002 & $16,611,710$ & NA & $1,602,970$ & NA & NA & $9.6 \%$ \\
\hline Fall 2003 & $16,911,481$ & $1.8 \%$ & $1,971,397$ & 368,427 & $23.0 \%$ & $11.7 \%$ \\
\hline Fall 2004 & $17,272,043$ & $2.1 \%$ & $2,329,783$ & 358,386 & $18.2 \%$ & $13.5 \%$ \\
\hline Fall 2005 & $17,487,481$ & $1.2 \%$ & $3,180,050$ & 850,267 & $36.5 \%$ & $18.2 \%$ \\
\hline Fall 2006 & $17,758,872$ & $1.6 \%$ & $3,488,381$ & 308,331 & $9.7 \%$ & $19.6 \%$ \\
\hline Fall 2007 & $18,248,133$ & $2.8 \%$ & $3,938,111$ & 449,730 & $12.9 \%$ & $21.6 \%$ \\
\hline Fall 2008 & $19,102,811$ & $4.7 \%$ & $4,606,353$ & 668,242 & $16.9 \%$ & $24.1 \%$ \\
\hline Fall 2009 & $19,524,750$ & $2.2 \%$ & $5,579,022$ & 972,669 & $21.1 \%$ & $28.6 \%$ \\
\hline Fall 2010 & $19,641,140$ & $0.6 \%$ & $6,142,280$ & 563,258 & $10.1 \%$ & $31.3 \%$ \\
\hline
\end{tabular}

Although faculty may perceive online courses as taking considerably more time to teach, they understand the benefits of online instruction. Hilsop and Ellis's (2004) study found that almost all (99\%) of faculty valued flexible access to courses for students and faculty. Faculty overwhelmingly agreed that it is important for them to have the 
flexibility to offer courses online that would provide educational opportunities for underserved student populations. In addition, most faculty from Hislop and Ellis's study felt students were actively involved in learning when enrolled in online coursework (95\%), that the technology they use is reliable (93\%), and that they looked forward to teaching their next online course $(93 \%)$.

Beyond this, faculty fear that abandoning traditional, face-to-face settings will disrupt student involvement and create a less personal and accessible environment for students is also very real. Wasilik and Bollinger (2009) found that technology-related problems, lack of face-to-face contact with students, and the lack of student involvement in the online environment are three concerns that faculty have about online teaching. In addition, their study found that participants were concerned about students cheating and limited interaction with their colleagues. While these fears must be taken into consideration, it is equally important to acknowledge that the technology is changing the world, and education must find a way to change with the technology. Regardless of whether professors utilize instructional technology or not, more than ever students in the United States have access to smartphones, laptops and tablets. Professors have the choice to either ignore the new technologies that students are familiar with, or find meaningful ways to embrace these technologies to support their instruction by increasing student engagement.

United States faculty are aware of the benefits and ubiquity of social media among the general population. Moran, Seaman and Tinti-Kane (2011), for example, note that over $90 \%$ of faculty report they are familiar with social media applications such as 
Myspace, Facebook, Twitter, YouTube, and blogs. However, the awareness level drops somewhat for less popular sites. Frequency of faculty use of social media as reported by Moran, Seaman and Tinti-Kane (2011) is depicted in Figure 6. While over 80\% of faculty are aware of common social media applications such as Twitter and Facebook, Seaman \& Kane (2011) report that less than one-half of faculty report they are aware of applications such as "SlideShare" a presentation-sharing site. While it is positive that faculty are becoming more aware of social media applications, awareness of tools that would be beneficial for instruction is still limited.

Figure 6. Frequency of Faculty Profession Use of Social Media

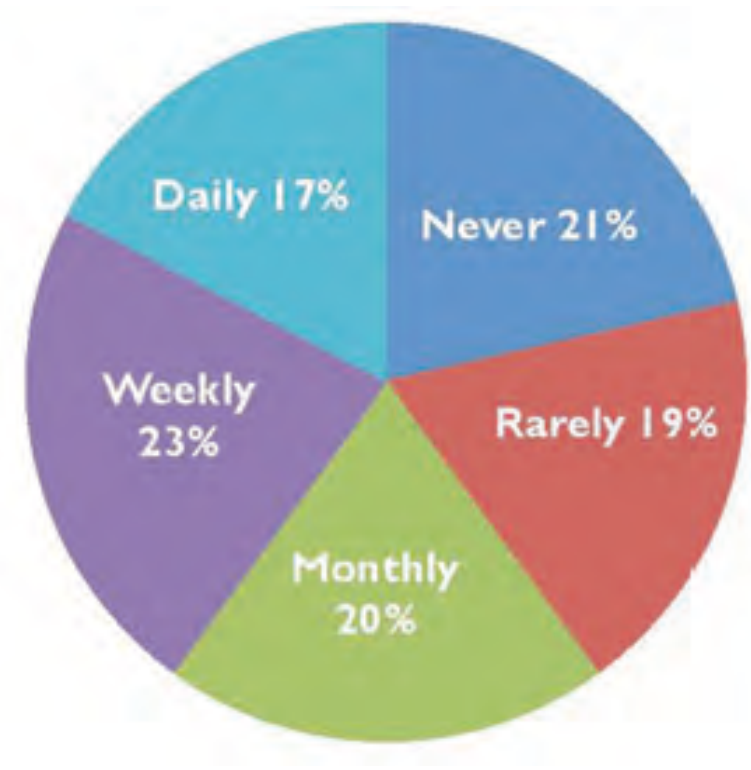

In an article titled "Findings on Facebook in higher education," McDaniel (2010) suggests that faculty who see teaching as establishing a relationship with students may view Facebook-like technologies as an efficient or even a business-like way to interact 
with students to establish relationships. His research further found that faculty and students do not differ in the frequency with which they check their social media applications for messages. This finding suggests that although some faculty may bemoan the use of technology in their classrooms, they remain equally as connected their social media accounts as their students. Using social media applications to promote greater faculty-student interactions seems like an obvious next step for integration technology with instruction given the fact that faculty are beginning to show the same interest in accessing their social media accounts throughout the day as their students.

\section{Perceptions Influencing Technology Use and Adoption}

Davis's (1989) seminal article investigating factors that influence technology acceptance and use provides a foundation for understanding factors that determine faculty's use of technology for communication with students and instruction. Davis's Technology Acceptance Model (TAM) is based on Fishbein and Ajzen's (1975) attitude paradigm, which theorizes that external stimuli (for example an ICT system) are causally linked to beliefs, attitudes and behavior. Using Fishbein and Ajzen's theory, Davis proposed that attitude toward using technology is a function of two beliefs; perceived usefulness and perceived ease of use. Perceived usefulness is the degree to which an individual believes that technology would improve his/her job performance while perceived ease of use is considered the degree to which a technology is easy to understand, operate and is free from effort (Davis, 1993; Rogers, 2003). The Technology Acceptance Model hypothesizes that the more positive perceptions individuals have 
regarding ease of ICT use and value of ICT use, the more likely they are to use ICT tools in their professions. The Technology Acceptance Model first proposed and researched by Davis in 1989 is represented in Figure 7.

Figure 7. Technology Acceptance Model

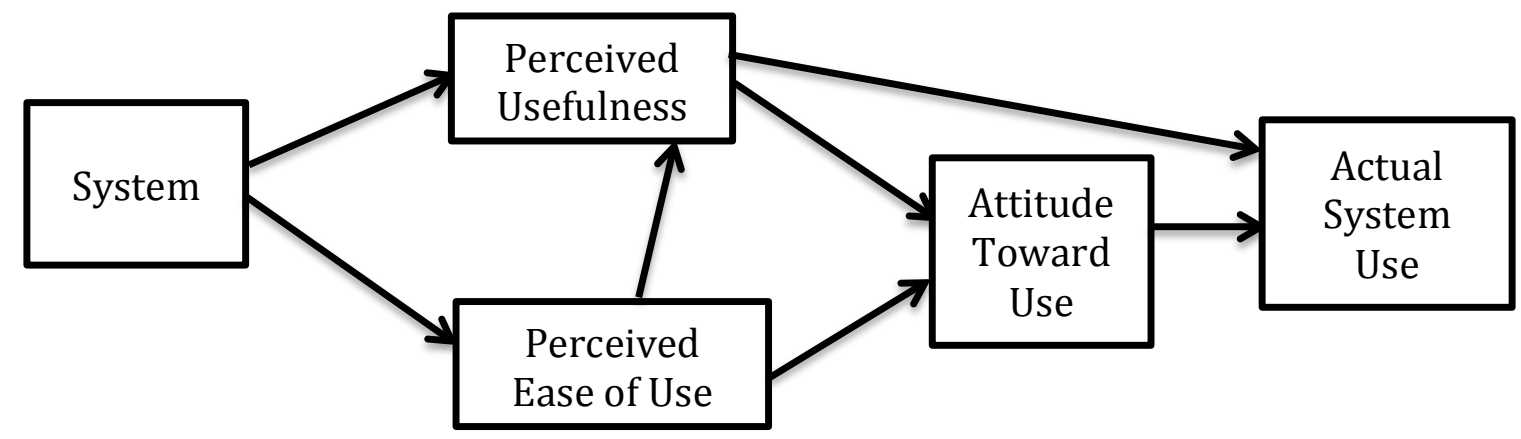

Davis conducted a path analysis using ordinary least squares regression to determine the relationships represented in Figure 7. Data for the study was collected from 112 professional and managerial employees from a large North American Corporation who were asked to complete a questionnaire related to two software systems, an electronic mail system and text editor. Participants were asked to indicate how often (Don't use at all, Use less than once a week, Use about once a week, Use several times a week, Use about once a day, and Use several times a day) they used electronic mail each week and how many hours they used the electronic email system. In addition, they were also asked to complete items that measured their attitude or favorability toward using the two software systems, perceived ease of use and perceived usefulness of the two software systems. Results from Davis's research found that attitude had a significant effect on 
usage; perceived usefulness had a significant and strong effect on attitude; while ease of use had a small but significant effect on attitude and a significant effect on perceived usefulness.

The Technology Acceptance Model has been investigated by other researchers. For example, Ajjan and Hartshone (2008) investigated factors that influence faculty decision to use Web 2.0 technologies. As part of a larger study, they examined the relationships between faculty's attitude, perceived usefulness, ease of use, compatibility with teaching style and intention to use Web 2.0 technology. Results from their study found as was the case with Davis' study that perceived usefulness and ease of use were significantly related to attitude toward web 2.0 use, which in turn was the largest determinant of intention by faculty to use Web 2.0 technologies. Davis's seminal work along with that of Ajjan and Hartshone suggest that developing faculty attitude toward the use of Information and Communication technologies is critical to support adoption of new technologies that can support learning in higher education environments. Clearly as described earlier ease of use and perceived value are important contributors to faculty's overall attitudes toward technology use. This finding suggests that faculty's perceived ease of use and usefulness of information and communication technologies is related to the level of technology access, technical support and training available to them.

\section{Summary}

There are two identifiable instructor-based impediments to implementing technology in learning: instructor reluctance to use technology in the classroom and a 
lack of knowledge of or proficiency with technological resources. In other words, there is an underlying failure in the educational delivery system when it comes to instructors themselves. Regardless, the necessity of implementing technology in education continues to grow. As technology becomes an increasingly intrinsic part of students' lives, a lack of instructor competence with technology results in an instructor's authority as a source for learning being questioned as well. Accordingly, it is critical that the gap between inschool and out-of-school use of be bridged. In order to effectively implement the use of technology in education, three key elements must be consistently met: the technology must be routinely used and transparent, it must be accessible and available, and must support curriculum goals. The implementation of technology in education has added benefits for countries, like Saudi Arabia, which function under different social norms. In Saudi Arabia, for example, the implementation of technology in educational delivery systems has the additional benefit of fostering gender equality as it presents an as-of-yet unrealized potential to educate a greater number of women, and educate them at a higher level. The traditional prohibition on mixed-gender classrooms in Saudi Arabia impedes the education of women and contributes to continued gender inequality. The implementation of technology in designing education delivery system allows students to engage in lower level cognitive learning using a variety of educational tools and at a pace that meets the student's learning speed. Students can learn how they want and when they want; these two options mirror the requirements of accessibility and availability set forth above. The use of technology in educational delivery systems not only affords a student his or her choice of educational platform from which to learn, but has the added benefit 
of increasing student participation because an alternative delivery system affords the student protections that are not available in a face-to-face learning environment. The old adage that people will say in emails things they would not dare to say in person has a positive impact in this instance - a student unwilling to speak in class may be willing to communicate in an electronic forum.

The instructor-based limitations discussed above (reluctance to utilize and lack of training) are similarly reflected in studies that have been conducted on Synchronized Interactive Online Instruction. Those studies reflect that professor facilitation of SIOI has a greater impact on student learning that the course design itself. Thus, the unwillingness or inability of a professor to accommodate an on-line learning format adversely impacts the value of that educational delivery system. Saudi Arabia has added social barriers to overcome in implementing technology in education delivery systems; specifically, cultural beliefs and ideas about the nature of the education system. Widespread acceptance and adoption of technology in education will not be achieved until these beliefs change or evolve. The continued embrace of these attitudes combines with a lack of training and technical support. Again, the principles relating to instructor-based barriers are reflected here. In the United States, educators hold the misperception that online courses require a greater instructor time commitment. While the flexibility of online delivery is noted as a positive, negative perceptions relating to issues with the technology, the lack of face-to-face interaction, and the increased potential of increased unorthodox student interaction continue to beguile widespread acceptance. 
Fundamentally, the usefulness of technology in education and the ease of use, for both instructor and student, are key components of successful implementation. 


\section{CHAPTER THREE}

\section{METHODS}

\section{Introduction}

The purpose of this comparative descriptive study is to determine what types of technologies Saudi university instructors use to support learning. Results from this study would inform leadership in the Ministry of Higher Education about the use of the types of technologies that higher education faculty use and the available technologies that are likewise not used to support learning in higher education contexts.

\section{$\underline{\text { Research Questions }}$}

1. What Information and Communication Technology tools do Saudi and United States faculty indicate that they use most frequently for communicating with students and for instruction?

2. How many hours per week do Saudi and United States faculty estimate they use ICT tools to communicate with their students and for instruction?

3. How do Saudi and United States faculty perceptions of ease of use, perceived value, attitude toward the use of Information and Communication Technology and actual ICT use relate to one another? 


\section{$\underline{\text { Research Design }}$}

This study used a descriptive, cross-sectional a survey design to collect data to investigate how Saudi and United States faculty use Information and Communication Technology tools for communicating with students and for instruction. A cross-sectional design is one where data about individual's perceptions, attitudes and beliefs are collected at one specific point in time (Gay, Mills, \& Airasian, 2012). Gay, Mills \& Airasian (2012) suggest that survey research is appropriate for this study because it allows for the efficient collection of data from a sample that is representative of a large population.

\section{Participants}

A convenience sample of Education faculty from five Saudi universities and six universities from the United States completed the questionnaire designed to gather perceptions of their use of electronic tools for communication with students and instruction. Three hundred and five Saudi faculty and 268 United States faculty completed the questionnaire. The eleven institutions representing the 573 faculty participants are reported in Table 4. 
Table 4. Saudi and United States Faculty Participants

\begin{tabular}{|l|l|}
\hline Saudi Institutions & United States Institutions \\
\hline King Saud University & Minot State University \\
\hline King Khalid University & Montana State University \\
\hline Imam Muhammad Ibn Saud University & Stanford University \\
\hline Umm Al-qura University & University of Michigan \\
\hline Taibah University & Washington State University \\
\hline & Wayne State University \\
\hline
\end{tabular}

Demographic results reported in Table 5 indicate that approximately 77 percent of Saudi faculty participants were female while the remaining $23 \%$ were males. In addition the mean for Saudi faculty was approximately 32 years $(\mathrm{SD}=10.4)$ and the average number of years teaching was $8.2(\mathrm{SD}=12.26)$. The gender composition for the United States faculty was fairly even with 51\% male and $49 \%$ female. The average age of the United States faculty was approximately 48 years $(S D=14.82)$ while the average years of teaching experience was $15(\mathrm{SD}=13.32)$.

Table 5. Participant Demographics

\begin{tabular}{|c|c|c|c|c|c|}
\hline Saudi Faculty & $f$ & $\%$ & United States Faculty & $f$ & $\%$ \\
\hline Gender & & & Gender & & \\
\hline Male & 222 & 76 & Male & 130 & 51 \\
\hline \multirow[t]{2}{*}{ Female } & 70 & 24 & Female & 123 & 49 \\
\hline & $M$ & $S D$ & $M$ & $S D$ & \\
\hline Age & 31.7 & 10.4 & 47.74 & 14.82 & \\
\hline Years Teaching Experience & 8.17 & 12.26 & 15.02 & 13.32 & \\
\hline
\end{tabular}

Table 6 shows that only a little over one-fourth of Saudi faculty taught all or part of a course online as compared to $65 \%$ for United States Faculty. In addition, nearly $60 \%$ 
of Saudi faculty reported never teaching an online course as compared to only $13 \%$ for United States faculty. The most frequently reported learning management systems reported used by Saudi faculty was Blackboard (82\%) followed by Moodle (10\%). Similarly, the United States faculty participants reported using the learning management system Blackboard (50\%) most frequently followed by Moodle (34\%) and Desire to Learn $(28 \%)$.

Table 6. Saudi and United States Faculty Experience Using Electronic Tools

\begin{tabular}{|c|c|c|c|c|c|}
\hline \multirow[t]{2}{*}{ Saudi Faculty } & & & United States Faculty & & \\
\hline & $f$ & $\%$ & & $f$ & $\%$ \\
\hline \multicolumn{6}{|l|}{$\begin{array}{l}\text { Taught Part or All of an } \\
\text { Online Course }\end{array}$} \\
\hline Yes & 76 & $26 \%$ & & 169 & $65 \%$ \\
\hline No & 217 & $74 \%$ & & 90 & $35 \%$ \\
\hline \multicolumn{6}{|l|}{$\begin{array}{l}\text { Learning Management } \\
\text { System Use }\end{array}$} \\
\hline Desire-to-Learn & 16 & $6 \%$ & & 73 & $28 \%$ \\
\hline Blackboard & 85 & $29 \%$ & & 128 & $50 \%$ \\
\hline Moodle & 28 & $10 \%$ & & 89 & $34 \%$ \\
\hline Other & 27 & $9 \%$ & & 43 & $17 \%$ \\
\hline Never Used & 165 & $57 \%$ & & 33 & $13 \%$ \\
\hline
\end{tabular}

Table 6 Note: Percent of Learning Management Systems used exceeds $100 \%$ because faculty may have used more than one. 


\section{Instrument}

The questionnaire used for this research was based on the work of Payette \& Verreault (2007). In addition, questions related to faculty perception of the ease of use, value and attitude toward the use of electronic tools was based on the work of Aijan and Hartstone (2008) and Tabata and Johnsrud (2008). The first part of the questionnaire asked respondents to indicate their gender, age, experience teaching and their experience with electronic tools used for communicating with students and teaching. The second section consisted of multiple choice that asked faculty to rate how often they use electronic tools for communication and teaching using the descriptors: $1=$ Never, $2=$ Seldom, 3 = Sometimes, $4=$ Often and $5=$ Always. In addition, faculty were asked to estimate the hours that they used electronic tools per week for communication and teaching. The final part of the questionnaire consisted of questions designed to elicit faculty perceptions Value, Ease of Use and Attitudes toward the use of ICT tools. In addition, to the fixed response questions, three open ended questions were posed to capture more in-depth descriptions of faculty's perceptions related to their use of electronic tools for connecting with students and teaching.

The content and construct validity of the questionnaire was established by having an expert panel review the items to further enhance construct validity (AERA, 1999; DeVellis, 2003; Zhang, 2003). Three professors of educational technology were asked to review items to evaluate their relevancy, clarity and conciseness (DeVellis, 2003). In addition, the survey was piloted with a small group of Saudi and United States faculty to gather additional feedback about the clarity and relevance of the items. In addition to the 
expert panel review and pilot study, results for both the Saudi and United States faculty responses to the Information and Communication Technology attitude items written to measure faculty perceptions of Ease of Use, Usefulness and Attitude were factor analyzed using principal components analysis.

Saudi faculty results from the principal component analysis found that the ICT attitude items loaded on similar constructs they were written to measure. However, two items, "I have the basic skills to use social networking software like Facebook or Twitter" and "Using technology will have a positive impact on my career as a professor" were removed due to large crossloadings on more than one factor. Thus it was determined these items were measuring very similar attitudes to other items that uniquely loaded on the factors and identified. Thus these two items were removed from the analysis. The Principal Components analysis using oblique rotation methods that allowed factors to correlate yielded four interpretable factors. The first interpreted as "Perceived Value" captured three of four perceived value items and one attitude item. The second factor was comprised of two attitude items and one item written to tap ease of electronic tool use. The third factor, Ease of Use, capture three of the four items written to tap respondents perceptions of ease of use of Information and Communication Technology. The fourth factor, Attitude, was comprised of one item written to assess attitude, one to measure Ease of Use and one item written to assess Perceived Value. The internal consistency reliabilities for the items comprising each factor were as follows: Perceived Value $=.83$, Skills and Access $=.81$, Ease of Use $=.60$ and Attitude $=.70$ for the the factor loadings, 
Means and Standard Deviations for each item by the respective factors is reported in

Table 7.

Table 7. Factor Loadings, Means and Standard Deviations

for Saudi Faculty ICT Attitude Items

\begin{tabular}{|c|c|c|c|c|c|c|c|}
\hline ITEMS BY FACTOR & $\mathrm{n}$ & 1 & 2 & 3 & 4 & $\mathrm{M}$ & $\mathrm{SD}$ \\
\hline \multicolumn{8}{|l|}{ Perceived Usefulness } \\
\hline $\begin{array}{l}\text { Using electronic tools in my course will help } \\
\text { students better learn the material. }\end{array}$ & 268 & .882 & $\begin{array}{l}- \\
.043\end{array}$ & .007 & -.018 & 3.90 & 1.01 \\
\hline $\begin{array}{l}\text { The advantages of using electronic tools } \\
\text { outweighs the disadvantages of not using } \\
\text { them. }\end{array}$ & 263 & .868 & .053 & -.003 & & 4.03 & .886 \\
\hline $\begin{array}{l}\text { Using electronic tools will improve student } \\
\text { satisfaction with the course. }\end{array}$ & 266 & .763 & $\begin{array}{l}- \\
.105\end{array}$ & .112 & .021 & 4.10 & .843 \\
\hline $\begin{array}{l}\text { The use of technological tools is important for } \\
\text { conducting professional work. }\end{array}$ & 265 & .433 & -307 & -.021 & .169 & 4.32 & .842 \\
\hline \multicolumn{8}{|l|}{ Skills and Access } \\
\hline $\begin{array}{l}\text { I have the basic skills for navigating the } \\
\text { Internet }\end{array}$ & 262 & -.009 & .901 & -.057 & .034 & 4.56 & .723 \\
\hline $\begin{array}{l}\text { I have access to a computer with productivity } \\
\text { software. }\end{array}$ & 265 & -.043 & .879 & -.045 & .040 & 4.52 & .749 \\
\hline $\begin{array}{l}\text { Using productivity software for } \\
\text { communicating with students and for } \\
\text { instruction is easy. }\end{array}$ & 269 & .108 & .640 & .120 & .054 & 4.47 & .804 \\
\hline \multicolumn{8}{|l|}{ Ease of Use } \\
\hline $\begin{array}{l}\text { Using courseroom management systems (e.g. } \\
\text { Blackboard, D2L, Moodle) for communicating } \\
\text { with students and instruction is easy. }\end{array}$ & 268 & .085 & $\begin{array}{l}- \\
.314\end{array}$ & .737 & -.243 & 3.90 & 1.10 \\
\hline $\begin{array}{l}\text { Using Web conferencing software (e.g. Skype, } \\
\text { Webex) for communicating with students and } \\
\text { instruction is easy. }\end{array}$ & 268 & -.023 & .022 & .732 & .211 & 3.47 & 1.10 \\
\hline $\begin{array}{l}\text { Using social media tools and other electronic } \\
\text { tools to communicate with students and for } \\
\text { instruction is stressful }\end{array}$ & 264 & .023 & .137 & .664 & .043 & 3.36 & 1.15 \\
\hline \multicolumn{8}{|l|}{ Attitude Toward ICT Use } \\
\hline $\begin{array}{l}\text { Using social media tools (e.g. Facebook, } \\
\text { Twitter) for communicating with students and } \\
\text { instruction is easy }\end{array}$ & 270 & .189 & .039 & .037 & .765 & 3.69 & 1.17 \\
\hline $\begin{array}{l}\text { I am skillful in using social media and } \\
\text { productivity electronic tools (e.g. Twitter, } \\
\text { Facebook, podcasts, videos) for } \\
\text { communicating with students and for } \\
\text { Instruction. }\end{array}$ & 264 & -.177 & $\begin{array}{l}- \\
.232\end{array}$ & .099 & .698 & 3.94 & 1.03 \\
\hline $\begin{array}{l}\text { Using electronic tools such as Facebook, } \\
\text { Podcasts, Videos, Skype to communicate with } \\
\text { students and for instruction is a good idea. }\end{array}$ & 265 & .394 & .020 & $\because .002$ & .599 & 4.06 & .983 \\
\hline
\end{tabular}


United States faculty results from the principal components analysis of ICT attitude items found that not all of the items loaded on the constructs they were written to measure. One item, “ Using technology will have a positive impact on my career as a professor" was removed due to multicollinearity with other items intended to measure the three traits of ICT use attitudes. The exploratory factor analysis using Principal Components extraction and oblique rotation methods constrained to extract three factors produced three underlying dimensions adequate for assessing the three constructs related to Ease of Use, Perceived Value and Attitude Toward Use of ICT. The first factor was interpreted as "Perceived Value" and captured all four perceived value items explaining $31 \%$ of the variance of the data structure. The second factor Ease of Use, was comprised of two Ease of Use items and one item written to tap Attitude toward electronic tool use. This second factor was responsible for $11 \%$ of the variance in the items analyzed. The third factor, Attitude Toward Use, captured two attitude items and one ease of use item. This factor was also explained $11 \%$ of the variance for all the items analyzed. Three items from the analysis, "Using Web Conferencing tools for communicating and instruction," "The use of electronic tools is important for conducting professional work" and Using social media and other electronic tools to communicate with students and for instruction" were removed due to their large crossloadings on the other three factors. The internal consistency reliabilities for the items comprising each factor were as follows: Perceived Value $=.81$, Ease of Use $=.60$ and Attitude $=.70$ for the factor loadings, Means and Standard Deviations for each item by the respective factors is reported in Table 8. 
Table 8. Factor Loadings, Means and Standard Deviations for United States Faculty ICT Attitude Items

\begin{tabular}{|c|c|c|c|c|c|c|}
\hline ITEMS BY FACTOR & $\mathrm{n}$ & 1 & 2 & 3 & $\mathrm{M}$ & SD \\
\hline \multicolumn{7}{|l|}{ Perceived Usefulness } \\
\hline $\begin{array}{l}\text { Using electronic tools in my course will help students } \\
\text { better learn the material. }\end{array}$ & 239 & 809 & -.150 & -.044 & 3.82 & .861 \\
\hline $\begin{array}{l}\text { The advantages of using electronic tools outweighs } \\
\text { the disadvantages of not using them. }\end{array}$ & 238 & .761 & -.290 & -.170 & 3.75 & .872 \\
\hline $\begin{array}{l}\text { Using electronic tools will improve student } \\
\text { satisfaction with the course. }\end{array}$ & 239 & .720 & -.240 & -.029 & 3.76 & .966 \\
\hline $\begin{array}{l}\text { Using electronic tools such as Facebook, Podcasts, } \\
\text { Videos, Skype to communicate with students and for } \\
\text { instruction is a good idea. }\end{array}$ & 239 & .740 & .166 & .061 & 3.42 & .949 \\
\hline \multicolumn{7}{|l|}{ Ease of Use } \\
\hline $\begin{array}{l}\text { Using productivity software for communicating with } \\
\text { students and instruction is easy. }\end{array}$ & 237 & .115 & -.733 & .002 & 4.27 & .778 \\
\hline $\begin{array}{l}\text { I have access to a computer with productivity } \\
\text { software. }\end{array}$ & 241 & -.031 & -.733 & .107 & 4.57 & .739 \\
\hline $\begin{array}{l}\text { Using Learning Management systems or } \\
\text { communicating with students and instruction is easy. }\end{array}$ & 237 & .200 & -.576 & -.011 & 3.89 & .943 \\
\hline \multicolumn{7}{|l|}{ Attitude Toward ICT Use } \\
\hline $\begin{array}{l}\text { I have the basic skills to use social networking } \\
\text { software like Facebook or Twitter. }\end{array}$ & 242 & -.152 & -.348 & .829 & 3.86 & 1.13 \\
\hline $\begin{array}{l}\text { I am skillful in using social media and productivity } \\
\text { electronic tools for communicating with students and } \\
\text { for Instruction. }\end{array}$ & 242 & .007 & -.150 & .821 & 3.24 & 1.20 \\
\hline $\begin{array}{l}\text { Using social media tools for communicating with } \\
\text { students and instruction is easy. }\end{array}$ & 236 & .326 & .354 & .543 & 3.10 & 1.08 \\
\hline
\end{tabular}

\section{Procedures}

As recommended by DeVellis (2011), the draft questionnaire was sent to an expert panel of United States education faculty at Montana State University and Boise State University for review. Next, the survey was translated into Arabic and sent to an expert review panel of education faculty at Imam Muhammad Ibn Saud University and King Khalid University. Both Saudi and United States faculty review panels provided feedback related to the relevancy, clarity, and conciseness of the survey items. Based on 
feedback from this expert review panel, items were further modified and piloted with education faculty from King Khalid University and Montana State University. Once again, the items were revised based on feedback from the pilot participants. The final version of the questionnaire was created using the Qualtrics Survey software and the link was sent to Saudi and United States faculty from the 11 universities listed in Table 1.

\section{Data Analysis}

Descriptive statistics in the form of percentages, means and standard deviations were used to answer the first two research questions posed to determine the frequency with which both Saudi and United States faculty used different type of ICT tools. In addition, independent samples t-tests were used to determine if ICT tools use differed significantly by Saudi and US faculty. Principal Components factor analysis was used to determine which ICT attitude items best measured faculty perceptions of perceived value, ease of use and attitudes toward the use of ICT tools. Another correlational method, Path analysis was used to determine the relationship between ease of use, perceived value, attitudes and actual use of electronic tools for both faculty groups. Path analysis is a technique that provides a visual representation of the relationships between variables being studied (Gay, Mills \& Airasian, 2012). Structural Equation Modeling using Lisrel 8.75 was used to calculate the path coefficients showing the relationships between Ease of Use, Percieved Value and Attitudes Toward ICT use. Structural Equation modeling is preferred over using Ordinary Least Square regressions because it takes measurement 
error into account providing more accurate estimates of the relationships between variables (Diamantopoulos \& Siguaw, 2009).

\section{Summary}

A questionnaire using the Qualatrics software was created to investigate Saudi and United States faculty use of electronic tools for communicating with students and to support student learning. Three hundred and five Saudi faculty and 268 United States faculty from eleven universities completed the questionnaire. Data from the questionnaire was analyzed both descriptively and using path analysis to answer the research questions posed for this study. 


\title{
CHAPTER FOUR
}

\section{RESULTS}

\author{
Introduction
}

The purpose of this comparative descriptive study was to identify the types of Information and Technology Communication (ICT) tools Saudi faculty and United States faculty use to support learning in higher education. In addition, this study was undertaken to explore the relationship between actual Information and Technology Communications Use and Saudi Faculty and United States faculty's perceptions of their ease of use, perceived value and attitudes toward use. Davis's (1993) Technology Acceptance Model was used as the model for investigating these relationships.

\section{Research Questions}

1. What Information and Communication Technology tools do Saudi and United States faculty indicate that they use most frequently for communicating with students and for instruction?

2. How many hours per week do Saudi and United States faculty estimate they use ICT tools to communicate with their students and for instruction?

3. How do Saudi and United States faculty perceptions of ease of use, perceived value, attitude toward the use of Information and Communication Technology and actual ICT use relate to one another? 


\section{$\underline{\text { Research Question } 1}$}

Research Questions 1 was answered using descriptive statistics for faculty ratings of how often they used Information and Communication technology tools. Both Saudi and United States faculty were asked to choose descriptors how often they used 18 different Information and Communication Technology (ICT) tools using the following Likert scale: 1 = "Never" (Not at all), 2 = "Rarely (less than weekly), 3="Sometimes" (Multiple times per week but not daily) and 4="All of the Time" (Daily). Table 9 reports the means and standard deviations for the ICT tools rated by Saudi and United States faculty. Results show that for Saudi faculty the most often used ICT tools were Email (m $=4.14, \mathrm{SD}=1.33)$ and Word Processing $(\mathrm{M}=4.14, \mathrm{SD}=1.17)$ followed by social media applications $(\mathrm{M}=3.39, \mathrm{SD}=1.62)$. US faculty also rated Email $(\mathrm{M}=4.29, \mathrm{SD}=.96)$

and word processing tools as the most frequently used ICT tools followed by Presentation tools $(\mathrm{M}=3.87, \mathrm{SD}=1.09$. Results from independent samples $t$-tests (alpha level $=.05)$ found that the largest discrepancy between Saudi and United States faculty was found for Social Media applications where Saudi Faculty indicated that they used social media applications significantly more often than United States faculty. In addition, Saudi faculty reported that they used Google Documents, Photos and Website links significantly more often than United States faculty. However, United States faculty indicated their use of podcasts and text documents significantly more often than Saudi faculty. 
Table 9. Means and Standard Deviations for Frequency of ICT Use for Saudi and United States Faculty

\begin{tabular}{|c|c|c|c|c|c|c|c|}
\hline ICT Application & & \begin{tabular}{|l} 
Saudi \\
Faculty
\end{tabular} & & United Sta & s Facu & & \\
\hline & n & $M$ & SD & n & $M$ & SD & $\mathrm{p}$ \\
\hline Email & 277 & 4.14 & 1.33 & 250 & 4.28 & .96 & .148 \\
\hline Social Media & 274 & 3.39 & 1.62 & 248 & 1.93 & 1.23 & $.001^{*}$ \\
\hline Video Conferencing & 289 & 2.18 & 1.26 & 252 & 2.38 & 1.18 & .057 \\
\hline Word Processing & 290 & 4.14 & 1.11 & 251 & 4.01 & 1.08 & .227 \\
\hline Spreadsheets & 290 & 3.03 & 1.41 & 250 & 3.00 & 1.38 & .991 \\
\hline $\begin{array}{l}\text { Presentations (e.g. } \\
\text { PowerPoint) }\end{array}$ & 288 & 3.92 & 1.21 & 250 & 3.86 & 1.09 & .702 \\
\hline Videos & 284 & 3.24 & 1.45 & 252 & 3.07 & 1.17 & .188 \\
\hline Podcasts & 288 & 1.68 & 1.09 & 250 & 1.90 & 1.22 & $.030^{*}$ \\
\hline Screencasts & 288 & 2.04 & 1.30 & 251 & 1.89 & 1.32 & .168 \\
\hline Photos & 282 & 3.47 & 1.43 & 253 & 2.92 & 1.32 & $.000^{*}$ \\
\hline Google Documents & 280 & 2.79 & 1.50 & 248 & 2.47 & 1.29 & .021 \\
\hline $\begin{array}{l}\text { Portable Document } \\
\text { Files }\end{array}$ & 287 & 3.70 & 1.41 & 248 & 3.62 & 1.19 & .600 \\
\hline $\begin{array}{l}\text { Instructor Created } \\
\text { Webpages }\end{array}$ & 288 & 1.69 & 1.13 & 250 & 1.89 & 1.22 & .050 \\
\hline Webinars & 285 & 1.77 & 1.01 & 2552 & 1.71 & 1.01 & .565 \\
\hline Text Documents & 282 & 2.65 & 1.45 & 250 & 2.99 & 1.44 & $.002^{*}$ \\
\hline Website links & 290 & 2.77 & 1.45 & 251 & 3.39 & 1.22 & $.000^{*}$ \\
\hline Concept Maps & 288 & 2.10 & 1.28 & 251 & 1.93 & 1.21 & .172 \\
\hline$B \log s$ & 289 & 1.90 & 1.21 & 251 & 1.87 & 1.11 & .599 \\
\hline
\end{tabular}

Table 9 Note: Electronic tools were rated by faculty using a five-point Likert scale where $1=$ Never (Not at all), $2=$ Rarely (less than weekly), $3=$ Sometimes (multiple times a week but not daily), $4=$ All of the Time (Daily), Always (Multiple times a day)" for each question. ${ }^{*} p<.05$

\section{Research Question 2}

Saudi and U.S. faculty were also asked to estimate the number of actual hours they used four broad categories of ICT tools for communication with students and instruction. Descriptive statistics for the estimated hours as well as independent samples t-tests were used to compare Saudi and United States faculty estimated weekly use of ICT applications for communicating with students and instruction. Results reported in Table 
10 show that Saudi faculty on average used Social Media for both instruction $(M=17.37$, $\mathrm{SD}=28.24)$ and Email for communication $(\mathrm{M}=16.74, \mathrm{SD}=25.86)$ more hours per week than the other categories of ICT tools. However, Email for instruction $(\mathrm{M}=16.36, \mathrm{SD}=$ $26.79)$ and the use of social media tools for communication $(\mathrm{M}=15.78, \mathrm{SD}=25.97)$ were estimated to be used more slightly less per week but more hours per week than video or audio ICT tools. US faculty reported using social media applications for communication $(\mathrm{M}=14.75, \mathrm{SD}=27.58)$ and instruction $(\mathrm{M}=14.57, \mathrm{SD}=28.50)$ as well as Email for communication $(\mathrm{M}=14.14, \mathrm{SD}=19.02)$ more hours per week than the other ICT tools but less hours per week than Saudi faculty. However, US faculty used Audio for both instruction $(\mathrm{M}=3.42, \mathrm{SD}=26.53)$ and communication $(\mathrm{M}=12.17, \mathrm{SD}=24.25)$, which was reported to be used more by faculty than Email for instruction, and video conferencing.

The only significant finding from independent sample t-tests (alpha level $=.05)$ was for the comparison of the use of email for instruction. Saudi faculty indicated they used email on average significantly more hours per week than United States faculty.

\section{$\underline{\text { Research Question } 3}$}

Research Question 3 was answered by conducting separate path analyses for both the Saudi and United States faculty's perceptions of ICT ease of use, ICT perceived value, Attitude Toward ICT use and actual ICT use. 
Table 10. Means and Standard Deviations for Hours of Actual ICT Use for Saudi and United States Faculty

\begin{tabular}{|l|c|c|c|c|c|c|c|c|}
\hline $\begin{array}{l}\text { ICT Application } \\
\text { Category }\end{array}$ & \multicolumn{1}{|c|}{$\begin{array}{c}\text { Saudi } \\
\text { Faculty }\end{array}$} & \multicolumn{4}{|c|}{ United States Faculty } & \\
\hline & $\mathrm{n}$ & $\mathrm{M}$ & $\mathrm{SD}$ & & $\mathrm{n}$ & $\mathrm{M}$ & $\mathrm{SD}$ & $\mathrm{p}$ \\
\hline $\begin{array}{l}\text { Email } \\
\text { Communication }\end{array}$ & 270 & 16.74 & 25.826 & & 245 & 14.14 & 19.02 & .266 \\
\hline $\begin{array}{l}\text { Email } \\
\text { Instruction }\end{array}$ & 250 & 16.36 & 26.79 & & 194 & 10.51 & 20.44 & $.015^{*}$ \\
\hline $\begin{array}{l}\text { Social Media } \\
\text { Communication }\end{array}$ & 220 & 15.78 & 25.97 & & 115 & 14.57 & 28.50 & .755 \\
\hline $\begin{array}{l}\text { Social Media } \\
\text { Instruction }\end{array}$ & 210 & 17.37 & 28.24 & & 95 & 14.75 & 27.58 & .467 \\
\hline $\begin{array}{l}\text { Video Conferencing } \\
\text { Communication }\end{array}$ & 169 & 12.69 & 23.38 & & 108 & 10.62 & 22.32 & .361 \\
\hline $\begin{array}{l}\text { Video Conferencing } \\
\text { Instruction }\end{array}$ & 158 & 13.37 & 24.43 & & 135 & 10.30 & 21.58 & .349 \\
\hline $\begin{array}{l}\text { Audio } \\
\text { Communication }\end{array}$ & 131 & 8.449 & 19.39 & & 89 & 12.17 & 24.25 & .219 \\
\hline $\begin{array}{l}\text { Audio } \\
\text { Instruction }\end{array}$ & 122 & 7.48 & 17.90 & & 84 & 13.42 & 26.53 & .059 \\
\hline
\end{tabular}

Table 10 Note: ${ }^{*} p<.05$

\section{Path Analysis for Saudi Faculty}

The path analysis results for Saudi faculty exploring the relationships between System Use or individuals' use of electronic tools and devices, Perceived Value, Ease of Use, Attitudes Toward ICT Use and actual ICT tool Use are located in Table 11. The fourth factor, Skills and Access identified by the factor analysis of the Saudi ICT attitude items, was not used in the analysis because this construct did not align with Davis' Technology Acceptance Model.

For this analysis, system was measured by how often faculty indicated they used Email, Social Media, Web Conferencing and Audio. Faculty were asked to indicate: Never $=1$, Rarely $=2$, Sometimes $=3$, Often $=4$, Always $=5$ for each of the four general 
categories of ICT tools. The latent traits of Perceived Value, Ease of Use and Attitude

Toward ICT Use were measured using the items identified by their respect factors

reported in Table 8 . ICT Use was measured by estimating the number of hours that Saudi

faculty indicated they used Email, Web Conferencing, Video and Audio per week. Audio was dropped from the analysis because less than one-third of Saudi faculty indicated that they used Audio for communication or instruction. The path coefficients are reported in Figure 8. The correlation matrix of variables used for the Saudi faculty path model analysis is reported in Table 11.

Table 11. Correlation Matrix of Variables for Saudi Faculty Path Analysis

\begin{tabular}{|l|l|l|l|l|l|l|l|l|l|l|l|l|l|l|l|l|l|l|l|}
\hline & Syst1 & Syst2 & Syst3 & Syst4 & Email & SM & Video & V2 & A5 & E3 & E4 & V1 & V3 & V4 & A2 & A3 & A4 & A6 & E5 \\
\hline Syst1 & 1.00 & & & & & & & & & & & & & & & & & & \\
\hline Syst2 & .596 & 1.00 & & & & & & & & & & & & & & & & & \\
\hline Syst3 & .423 & .308 & 1.00 & & & & & & & & & & & & & & & & \\
\hline Syst4 & .598 & .604 & .496 & 1.00 & & & & & & & & & & & & & & & \\
\hline Email & .167 & .337 & .173 & .378 & 1.00 & & & & & & & & & & & & & & \\
\hline SM & .208 & .188 & .105 & .237 & .595 & 1.00 & & & & & & & & & & & & & \\
\hline Video & -.052 & .107 & .035 & .103 & .385 & .458 & 1.00 & & & & & & & & & & & & \\
\hline V2 & -.097 & -.050 & .081 & .045 & -.026 & .049 & .016 & 1.00 & & & & & & & & & & & \\
\hline A5 & -.151 & -.070 & .022 & -.093 & -.015 & .022 & -.043 & .479 & 1.00 & & & & & & & & & & \\
\hline E3 & -.096 & -.067 & .039 & -.053 & .052 & .040 & .046 & .352 & .298 & 1.00 & & & & & & & & & \\
\hline E4 & -.082 & -.046 & .100 & -.066 & .079 & .022 & .103 & .181 & .479 & .538 & 1.00 & & & & & & & & \\
\hline V1 & -.137 & -.099 & .055 & .029 & -.033 & -.001 & -.008 & .482 & .480 & .351 & .353 & 1.00 & & & & & & & \\
\hline V3 & -.183 & -.111 & -.044 & -.088 & -.128 & -.036 & .119 & .434 & .387 & .243 & .334 & .633 & 1.00 & & & & & & \\
\hline V4 & -.074 & .018 & .066 & .081 & -.026 & .037 & .069 & .642 & .452 & .367 & .253 & .560 & .532 & 1.00 & & & & & \\
\hline A2 & .029 & .069 & .069 & .005 & -.053 & .100 & .031 & .294 & .570 & .201 & .361 & .449 & .327 & .400 & 1.00 & & & & \\
\hline A3 & .024 & .035 & .127 & .063 & -.038 & .094 & .080 & .428 & .369 & .245 & .250 & .344 & .313 & .396 & .681 & 1.00 & & & \\
\hline A4 & .006 & .070 & .168 & .092 & .009 & .101 & .088. & .463 & .336 & .296 & .274 & .327 & .207 & .394 & .431 & .672 & 1.00 & & \\
\hline A6 & -.318 & -.233 & -.053 & -.142 & -.116 & -.072 & .021 & .439 & .475 & .250 & .263 & .570 & .515 & .446 & .505 & .528 & .417 & 1.00 & \\
\hline E5 & -.078 & -.097 & .110 & .019 & .035 & .048 & -.047 & .216 & .101 & .264 & .328 & .274 & .139 & .201 & .095 & .167 & .156 & .240 & 1.00 \\
\hline
\end{tabular}

Table 11 Note: Syst $1=$ How often faculty used email, Syst $2=$ How often faculty used Social Media, Syst3=How often faculty used audio, Syst $4=$ How often faculty used audio, Email=estimated hours per week of email use, SM=estimated hours per week of social media use, Video=estimated hours per week of video use, V1-V4=Perceived Value items, E3-E5=Ease of Use items, A2-A6=attitude toward ICT use items 
Figure 8. Saudi Faculty Path Diagram

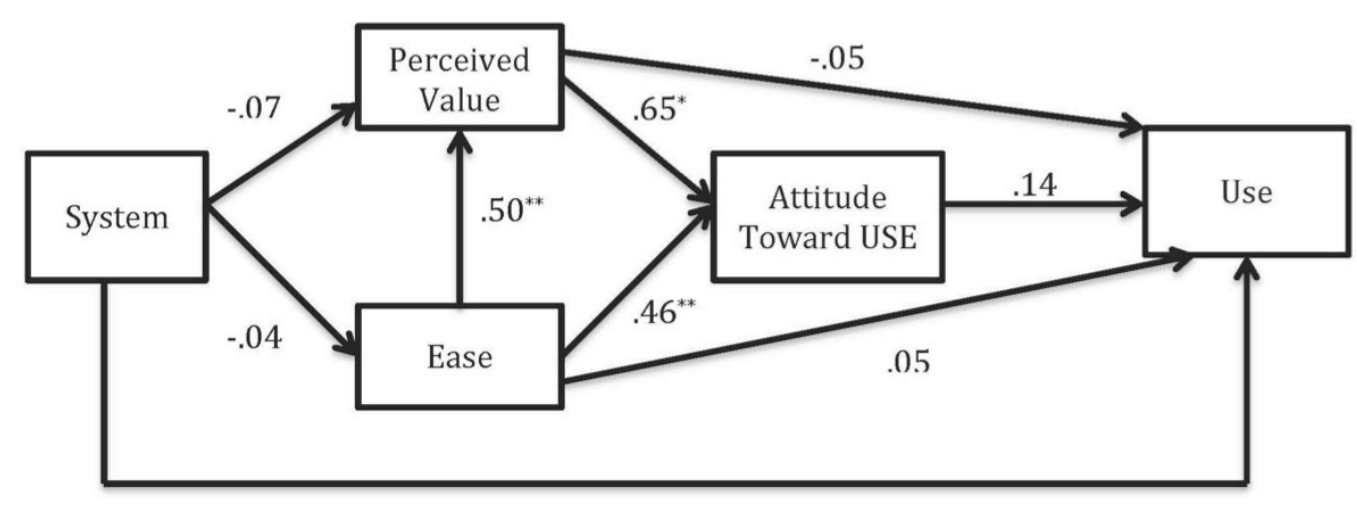

$.39^{*}$

The Root Mean Square Error of Approximation (RMSEA) was .067

indicating "reasonable" model fit according to criteria established by Browne and Cudeck (1993). Results from the path analysis for the Saudi faculty found that there was no significant relationship between Perceived Value, Ease of Use, Attitude and actual Use of Electronic tools for Saudi Faculty. However, System use was found to have a significant effect on Actual ICT Use ( $\beta=$. 39). In addition, Ease of Use was had a significant effect on Perceived Value $(\beta=.50)$ while Perceived Value was significantly related to Attitude Toward ICT Use ( $\beta$. 65). A significant indirect effect Ease of Use was found on Attitude when passing through Perceived Value $(\beta=.33)$.

\section{Path Analysis for United States Faculty}

The path analysis results for Saudi faculty exploring the relationships between System Use or individuals use of electronic tools and devices, Perceived Value, Ease of Use, Attitudes Toward ICT Use and actual ICT tool Use are located in Table 12. System 
use for the United States Faculty was measured by an overall of the hours they estimated they used ICT tools each week for communicating and instruction and an average rating of how often $($ Never $=1$, Rarely-less than weekly $=2$, Sometimes-Multiple times per week but not daily $=3$, and All of the Time-Daily $=4$ ) they used email for communicating with students. This indicator for US faculty is similar to how Davis (1993) measured system use for his original study of the Technology Acceptance Model. The latent traits of Perceived Value, Ease of Use and Attitude were measured using the items identified by their respective factors located in Table 9. The path coefficients for the United States faculty analysis are reported in Figure 9. The correlation matrix of variables used for the United States faculty path model analysis is reported in Table 12.

Table 12. Correlation Matrix of Variables for United States Faculty Path Analysis

\begin{tabular}{|l|l|l|l|l|l|l|l|l|l|l|l|l|l|l|l|l|}
\hline & A3 & E1 & V1 & V2 & V3 & V4 & E2 & A1 & A2 & Syst1 & Email & SM & Video & Audio & Syst2 & E3 \\
\hline A3 & 1.00 & & & & & & & & & & & & & & & \\
\hline E1 & -.110 & 1.00 & & & & & & & & & & & & & & \\
\hline V1 & -.126 & .302 & 1.00 & & & & & & & & & & & & & \\
\hline V2 & .031 & .348 & .805 & 1.00 & & & & & & & & & & & & \\
\hline V3 & -.070 & .473 & .573 & .813 & 1.00 & & & & & & & & & & & \\
\hline V4 & .251 & .177 & .263 & .340 & .496 & 1.00 & & & & & & & & & & \\
\hline E2 & -.223 & .428 & .426 & .450 & .531 & .342 & 1.00 & & & & & & & & & \\
\hline A1 & .313 & .199 & .395 & .440 & .172 & .269 & .065 & 1.00 & & & & & & & & \\
\hline A2 & .469 & .225 & .402 & .415 & .210 & .380 & -.091 & .719 & 1.00 & & & & & & & \\
\hline Syst1 & .011 & -.049 & -.499 & -.127 & .032 & .198 & -.064 & .095 & .008 & 1.00 & & & & & & \\
\hline Email & .227 & -.470 & -.470 & -.381 & -.282 & -.078 & -.266 & -.149 & -.034 & .382 & 1.00 & & & & & \\
\hline SM & .469 & -.641 & -.641 & -.296 & -.212 & .144 & -.558 & -.061 & .149 & .126 & .637 & 1.00 & & & & \\
\hline Video & .176 & -.257 & -.264 & -.310 & -.006 & .048 & -.359 & -.131 & .122 & .240 & .778 & .753 & 1.00 & & & \\
\hline Audio & .125 & -.048 & -.087 & -.144 & .091 & .096 & -.257 & -.150 & .096 & .126 & .550 & .679 & .783 & 1.00 & & \\
\hline Syst2 & -.179 & .202 & -.248 & -.231 & -.319 & -.236 & .035 & -.179 & -.168 & .017 & .127 & -.012 & .101 & .180 & 1.00 & \\
\hline E3 & -.025 & .233 & .148 & .111 & .168 & -.095 & .179 & .111 & -.060 & .134 & .060 & -.071 & .136 & .136 & .032 & 1.00 \\
\hline
\end{tabular}

Table 12 Note: $A 1-A 3=$ Attitude Toward ICT Use, E1-E3=Ease of Use items, V1-V4=Perceived Value items, Syst $1=$ estimated hours per week using ICT tools, Syst $2=e$ stimated hours per week using email, Email=How often faculty used email, $S M=$ How often faculty used social media, Video=How often faculty used video, Audio $=$ How often faculty used audio 
Figure 9. United States Faculty Path Diagram

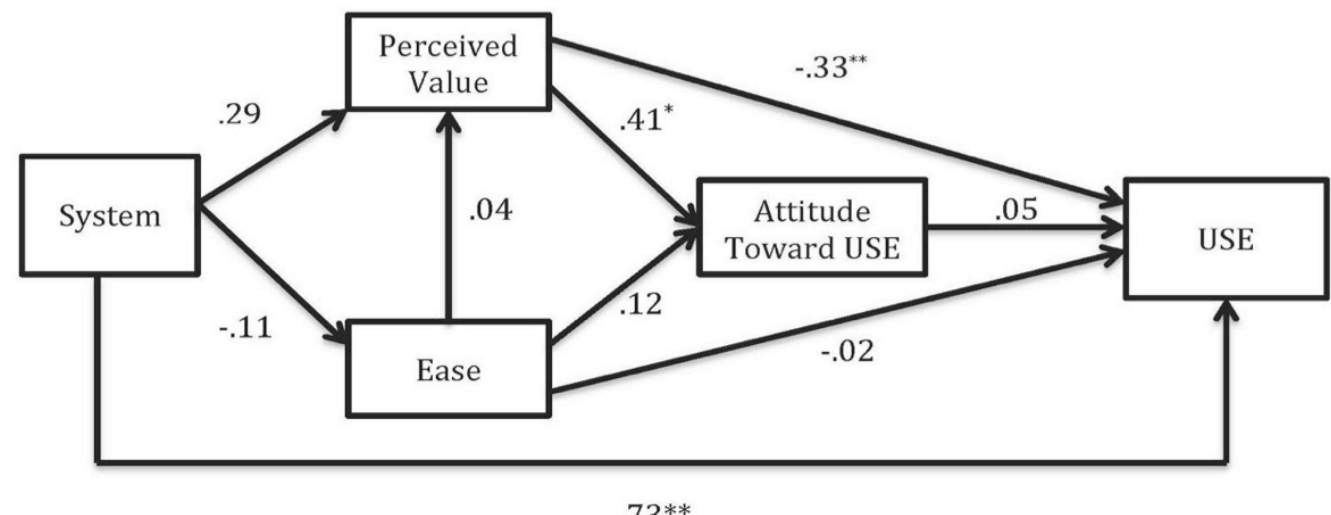

$.73^{* *}$

The Root Mean Square Error of Approximation (RMSEA) was .08 indicating "reasonable" model fit according to criteria established by Browne and Cudeck (1993). Results from the path analysis for United States faculty, found that there was no significant relationship between Perceived Value, Ease of Use, Attitude and actual ICT tools. However, System Use had was found to be significantly related to Actual ICT Use ( $\beta=.73)$. In addition, Perceived Value was found to have a significant effect on Attitude ( $\beta=.41)$. No significant indirect effects were found for System on Perceived Value and Use nor were their significant indirect effects for Ease of Use on Attitude or Use. Lastly, there were no significant indirect effects for Perceived Value on Use.

\section{Summary}

Descriptive and inferential results found that Saudi and United States faculty do differ much in their use of Information and Communication Technology tools. However, the one largest difference in the use of ICT tools for social media applications where 
Saudi faculty rated their use significantly more often than United States faculty. Additionally, Saudi faculty indicated that on average they spent significantly more hours per week using email for instruction than did United States faculty. Results from path analysis for Saudi faculty found that System Use had a significant effect on Actual Use of ICT tools ( $\beta=.39$ ). In addition, Ease of Use was found to have a significant effect on Perceived Value ( $\beta=.50)$ while Perceived Value had a significant effect on Attitude ( $\beta=.65$ ). A significant indirect effect Ease of Use was found on Attitude when passing through Perceived Value ( $\beta=.33)$. However, there were few significantly relationships for United States faculty when analyzing the relationships between System Use, Perceived Value, Ease of Use, Attitude and Use of ICT tools. For United States faculty System use had a significant effect on actual ICT Use $(\beta=.39)$. In addition, Ease of Use did not have a significant effect on Perceived Value (-.02). However, Perceived Value did have a significant effect on Attitude toward ICT tool use $(\beta=.41)$. 


\section{CHAPTER FIVE}

\section{DISCUSSION}

Access to Information Communication Technologies that support the use of audio, video, web conferencing and the Internet are providing many learning opportunities that were not available to students in the past. Over the past two decades the use of Computer and Internet Technology for instructional purposes has grown dramatically in Higher Education (Buchanan, Sainter, \& Saunders, 2013). Leaning management systems such as Blackboard, Desire-2- Learn and Moodle have integrate the use of ICT tools to allow faculty to create effective learning environments that will provide educational opportunities for students at a distance (Al-Zaidiyeen, Mei \& Fook, 2008). Online learning has significant potential benefits for students in both rural areas of Saudi and the United States where access to higher education is not available or for those who need flexibility in educational access due to work and other family situations (Hamdan, 2014). In addition, the increased used of online learning in Saudi Arabia would help to reduce overcrowding in the 25 Saudi Universities operated by the Saudi Ministry of Education (Alshari, 2012). The education system in Saudi Arabia is based on complete separation of students and staff by gender. The need to provide separate instructors in separate buildings for male and female students puts considerable strain on available resources. For example, according to Alaugab (2007), the number of female instructors is lower than male instructors at all academic levels. The use of E-learning and other ICT applications such as Web- Conferencing, Video and Audio have potential to provide 
coursework for female students in different facilities requiring a minimum number of female instructors.

However, the potential instructional, cultural and institutional benefits of these ICT tools cannot be realized unless faculty use them. The use of ICT applications are dependent on faculty perceptions such as the ease of use of ICT applications and their value for improving learning and instruction. The use ICT applications for education is relatively new for Saudi Faculty as compared to the United States counterparts. However, Saudi faculty, like United States faculty have increased access to the Internet that allows for more use of ICT applications through integrated courseroom learning management systems or using other stand alone social media, web-conferencing and other tools that incorporate both asynchronous or synchronous learning environments. It is of interest to know which ICT applications that Saudi and United States faculty use for interacting with students and instruction as well as their perceptions of the value of these applications based on their ease of use and their effectiveness for enhancing student learning.

This descriptive and exploratory study was undertaken to identify the types of Information Communication Technology tools Saudi and United States faculty use to communicate with students and to support learning in higher education. In addition, this study investigates the similarities and differences in technology use by Saudi and United States faculty and the relationships between perceived value and the ease of use of ICT tools their actual. Results from this study will also inform leadership in the Saudi Ministry of Higher Education as well as higher education in the United States about the 
types of ICT tools for interacting with students and to support instruction. A convenience sample of Education faculty from five Saudi universities and six universities from the United States completed the questionnaire designed to gather perceptions of their use of electronic tools for communication with students and instruction. Three hundred and five Saudi faculty and 268 United States faculty completed the questionnaire. The following research questions were posed for this study:

1. What Information and Communication Technology tools do Saudi faculty and United States faculty use most frequently for communicate with students and to support student learning?

2. What Information and Communication Technology tools do Saudi and United States faculty use to communicate with their students and for teaching?

3. How do Saudi and United States faculty perceptions of ease of use, perceived value, attitude toward the use of Information and Communication Technology and actual ICT use relate to one another?

\section{Conclusions}

Research Questions 1 and 2 were answered by asking both Saudi and US asked to rate how often they used 18 different Information and Communication Technology (ICT) tools use using the following scale: "Never" (Not at all), "Rarely (less than weekly), "Sometimes" (Multiple times per week but not daily) and "All of the Time" (Daily).

Results found that for Saudi faculty the most often used ICT tools were Email and Word Processing followed by social media applications. US faculty also rated Email and word 
processing tools as their most frequently used ICT tools followed by Presentation tools (e.g., PowerPoint) tools. Results from comparisons using independent samples t-tests revealed that Saudi faculty rated their use of social media applications significantly more often than United States faculty. Saudi faculty also rated their use of Google Documents and Photos significantly more often than United States faculty. However, United States faculty rated their use of podcasts and text documents significantly more often than Saudi faculty.

In addition, both Saudi and United States faculty were asked to estimate their actual hours of use per week for four broad ICT applications - which included email, social media, video and audio — for interacting with students and for instruction. Saudi faculty estimated that they used Email, Social Media and Video Conferencing more hours per week on average than did United States faculty. However, United States faculty reported using audio applications per week more often than Saudi faculty. This average hours per week of audio use was the only ICT category of application where Saudi and United States Faculty differed significantly.

Findings related to United States faculty for this study are similar to those reported by Keengwe (2007) who found that faculty use Web-browsers and multimedia presentation tools that integrate both video and audio several times per week. Alenzi's (2012) study investigating Saudi faculty members perceptions of e-learning found similar results to this study. His research indicated that Saudi faculty reported the most experience using productivity software including presentation software and word 
processing packages. Results from this study as well as Alenzi's research reported Saudi Faculty have less experience and use of video conferencing tools.

Interestingly, Saudi faculty reported using social media applications significantly more often that United States faculty. The pervasive use of social media applications in higher education and informally by Saudi faculty and university students alike is not surprising when considering that $50 \%$ of the population of Saudi Arabia, Yemen, Oman, Jordan, Morocco, and Egypt are currently estimated to be under 25 years of age. (Gannam, 2011). According to Gannam (2011), of the under-25 age group, 35-47 percent are characterized as those individuals belonging to the "net generation." Moran, Seaman \& Tinti-Kane (2011) surveyed over 1,900 United States faculty to investigate their use of social media tools. Their report found that the most frequently used social media application for instruction by $80 \%$ faculty surveyed was online video. However, the use of online video is different from how data on the use of social media applications were assessed for this study. Moran et al.'s report finds that only $11 \%$ of United States faculty use social media applications like Facebook or Twitter weekly for communicating with others confirming our findings that United States faculty use these social media applications several times per week.

Research Question 3, "Is there a relationship between perceptions of use, perceived value and attitude toward the use of Information and Communication Technology tools for Saudi and United States faculty" was answered by using path analysis using Lisrel 8.71 (Jöreskog \& Sörbom, 2005). This of this analysis for Saudi faculty found that there was a significant relationship between Perceived Value, Ease of 
Use, Attitude and actual Use of ICT tools for Saudi Faculty. However, external variables related to system use (frequency of ICT tool use) had a significant effect on actual ICT tool use. Ease of ICT tool use was found to have a significant effect on Perceived Value of ICT tools while Perceived Value and Ease of Use of ICT tools had a significant effect on Attitude toward the use of ICT tools.

Results of the path analysis of Saudi faculty from this study was similar to those found by Alkhalaf, Drew, AlGhamdi, and Alfarraj (2012) who investigated attitudes and perceptions of Saudi faculty members toward elearning. One of the major findings of their research was that Saudi faculty indicated that elearning was valuable because it improved their job performance. Likewise, a study conducted by Bendania (2011) with Saudi faculty from King Fahd University of Petroleum and Minerals found that like this study, faculty perceptions of the usefulness of ICT was significantly related to their attitudes toward using these ICT applications for online learning.

Results from the path analysis for United States faculty as was the case for Saudi Faculty found that there was no significant relationship between Perceived Value, Ease of Use, Attitude and actual ICT tool use for United States faculty. System use for the United States faculty had a significantly larger effect on actual ICT Use than was the case for Saudi faculty. Perceived Values was found to have a significant effect on Attitude. No significant direct effects were found for System on Perceived Value and Use of Use nor were their significant indirect effects for Ease of Use on Attitude Toward ICT use or actual ICT tool Use. Interestingly, Perceived Value had a significant and negative effect on Actual ICT Use, which suggests that United States faculty may value the use of more 
complex ICT technologies but do not use them as often because of the training requirements and time required to implement them. Athough Davis found a positive relationship between Perceived Value of ICT use and Actual Use, his sample was somewhat small and the ICT application was limited to email and a text editor. This study examined a wide range of ICT applications, some requiring much more time to learn and use. Jones (2004) finds that one of the largest barriers to ICT use is the lack of training that provides faculty with the confidence to use ICT applications. These results are different from those found by Davis's (1993) study of technology use by professional and managerial employees.

However, for the Saudi faculty there were some similarities to what Davis found. The path analysis for Saudi faculty found that Ease of Use of ICT tools had a significant effect on Perceived Value of ICT tools. Likewise, Perceived Value of ICT tools had a significant effect on Attitude Toward ICT tool use. However, there was no relationship between Attitude Toward ICT use and actual use of ICT tools as Davis found for his study. Similarly, results from this study were similar to those of Ajjan and Hartshorne's (2012) research examining factors related to faculty decisions to use Web 2.0 technologies. Their study found that Perceived Ease of Use and Perceived Usefulness were positively related to attitude toward the use of Web 2.0 applications. More specifically, as was the case with this study, Perceive Usefulness had a much stronger effect on Attitude Toward Use than did Perceived Ease of Use. Ajjan and Hartshorne, however, did not examine the relationship between Perceived Ease of Use and Perceived Value within the context of Web 2.0 tools. Their research found that Attitude Toward 
Use was significantly related to Intention to use Web 2.0 applications, which in turn was a significant determinant of actual Web 2.0 use. This study, however, did not find a significant relationship between attitude toward use of ICT tools and actual use of ICT tools for either Saudi or United States faculty.

\section{$\underline{\text { ICT Use and Learning Management Systems }}$}

Although ICT tools can be used independently, Learning Management Systems such as Blackboard, Desire-to-Learn and Moodle allow integration of these tools to create online and hybrid learning environments. Surprisingly, 57 percent of Saudi faculty indicated that they had used not Learning Management System for instruction as compared to only $13 \%$ of United States faculty. This finding is contradictory when considering results from how often faculty use ICT tools for communication and instruction. Some of the barriers cited for Saudi faculty's lack of use of Learning management systems (LMS) may be due to the limitations of the Jusur LMS developed by Saudi Arabia's National Center for E-Learning and Distance Learning (NCEL) (AlKhalifa, 2010). Jusur users reported difficulties in downloading course materials and uploading extensive files in the form of compressed folders. In addition, Jusur discussion forums are difficult to browse when attempting to interact with other users. Administratively, the Jusur LMS system does not allow faculty to remove or add students independently and it is not integrated with university registration or academic portals. Clearly the difficulties related to the use of the Jusur LMS likely affect faculty's 
perceptions of Jurs usefulness affecting their attitudes toward the use of Jusur and likely reducing their likelihood to use the Jusur system for instruction.

Learning Management systems other than Jusur are available to Saudi faculty. For example, the Saudi faculty completing the questionnaire for this study indicated that they had experience using Blackboard, Desire-to-Learn and Moodle. Even with access to other Learning Management Systems that have less limitations than Jusur, Saudi faculty are still concerned about the needed technical support and the capacity of infrastructure to manage the huge demand for E-learning in KSA to address the higher education needs of the $50 \%$ of the Saudi population that is under 25 years of age. Faculty support in terms of hardware, software, policies and procedures, and capacity to deal with problems that arise are major challenges for developed countries let alone developing countries like KSA (Piskurich, 2003).

United States faculty have similar concern with respect to the use of ICT tools and Learning Management Systems for online and hybrid learning. Although, the use of United Learning Management Systems by faculty such as Blackboard or Desire-ToLearn is commonplace, there is still concern about availability of training and institutional support (Tabata \& Johnsrud, 2008). This concern is well-founded because faculty cannot effectively integrate technology into their teaching and learning activities if they lack the skills to use ICT tools effectively in the classroom (Keengwe, Kidd \& Kyei-Blankson, 2008). Training and technical support will help faculty to overcome the anxieties associated with the use of ICT applications for instruction and help them to realize the value of these tools for improving instruction thus increasing their 
effectiveness as instructors (Johnson, Wisniewski, Kuhlemeyer, Isaacs \& Kryzkowski, 2008). We have evidence from research related to the Technology Acceptance Model (Alenzi, 2012; Ajjan \& Hartshone, 2008; Davis, 1993) that ease of ICT use and perceived value have large influences on faculty attitudes to engage in the use of ICT application to support their instruction. However, when training and support is not available, ease of use is compromised thus reducing the likelihood that faculty will integrate ICT tools into their instruction.

\section{$\underline{\text { Recommendations for Further Research }}$}

It is suggested that interviews and observations be conducted in addition to a survey similar to the one used for this study to verify the perceptions of faculty perceptions of ease of use, perceived value and attitude. The use of focus group interviews could help to design questions that are more specific to Saudi and United States faculty perceptions. Better indicators of attitude (ease of use, perceived value and attitude toward ICT Use) may provide a more accurate representation of the relationships between faculty attitude and their actual use of ICT applications for communication and learning. For example, it would be interesting to know how much time Saudi and US faculty spend using specific social media applications like Facebook and Twitter for communicating with students and for delivering instruction. Much of the research considers ICT applications such as Facebook, Twitter, YouTube and Instagram as one category of social media applications where as others classify Facebook and Twitter as

communication tools and YouTube as a multimedia application. These applications need 
to be more precisely defined and investigated in terms of their use for creating effective learning environments. In addition, factors such as gender, self-efficacy, and facilitating conditions should be added to the model to determine the influence of these factors on ease of use, perceived value, attitude toward ICT use and ultimately actual integration of ICT instructionally. In addition, more in-depth interview data may reveal other determinants of ICT application use other than those identified by Davis' (1993) Technology Acceptance Model and its variant, the Unified Theory of Acceptance and Use of Technology (UTAUT) developed by Venkatesh, Davis \& Davis, 2003).

\section{Summary}

Results from this study find that in general, Saudi faculty and United States faculty use ICT tools similarly for communication and learning. However, Saudi faculty attitudes toward the use of ICT tools are different from those of United States faculty. For United States faculty the use of ICT applications in general had much more effect on actual ICT use than for Saudi faculty. However, for Saudi faculty, ease of ICT tool use and perceived value of ICT tool use are important factors in their consideration of using ICT technologies. One reason for this may be that faculty in the U.S.. had much more access to ICT technologies and have engaged in the use of multiple ICT applications longer as compared to Saudi faculty. The importance of training to build confidence and competence is critical to the successful use of ICT applications. However, the literature suggests that although this is a barrier for all faculty related to the use of ICT, it is even more so for Saudi faculty. 
Saudi faculty report using social media applications significantly more often than United States faculty. On the other hand, United States faculty have much more experience using ICT tools within the context of Learning Management Systems. Findings from this study have important implications for higher education in both the Kingdom of Saudi Arabia and the United. As Saudi and US students continue to make increasing use of smartphones and other mobile devices for communication and as an instructional resource, faculty, particularly in the United States should make efforts to use ICT applications that will increase active engagement by allowing students to readily access instructional materials. For example, classroom activities and assignments could be created using social network applications to provide a way for students instantaneously interact with one another and the instructor to create new knowledge and understanding. These immediate text-based interactions can further enhance learning when accompanied by media-based resources such as videos, audio files and pictures. The use of Web 2.0 social networking tools can also be used also to support open communications between student and instructors. Students can receive more immediate clarification about assignments while instructors can provide more immediate feedback related to student performance. Short, electronic surveys or polls could also be created to allow students to anonymously express their opinions. Engaging students in this manner may serve to stimulate more in-depth discourse among students related to pertinent course topics.

Communication barriers that exist within the Saudi culture could also be reduced with the use of mobile devices and social media applications. In Saudi Arabia there is a 
deep respect by the young Saudi individuals for older family members and adults. Verbal interactions can be characterized as younger adults listening to the verbalizations of older family members and other older adults. The use of social media applications may provide a strategy that allows for balanced discourse between both young and old that otherwise would not occur when meeting face-to-face. Saudi students are expected to listen to the professor and are not encouraged to engage discussion or questioning. Social media applications such as facebook, Twitter and Instragram provide more opportunities for students and instructors to engage with one another in ways that is not culturally acceptable in public university classrooms. The use of ICT applications such as those considered Web 2.0 technologies in the higher education in both the Kingdom of Saudi Arabia and the United States may help to create a more interactive learning environment where students have opportunities to contribute to knowledge construction along side of their instructors.

This study shows that the use of Learning Management Systems is underutilized by Saudi faculty. E-learning through the use of reliable Learning Management systems has been suggested as a solution to the problem of overcrowded Saudi Universities (Alsiri, Mahmud, Bakar, Ayub \& Ayub, 2012). In addition, more use of Learning Management Systems by Saudi University faculty would provide educational opportunities for those in rural areas that have limited access to higher education resources. An important implication for Saudi female students is access to course materials and participation in collaborative learning activities through the use of e-learning facilitated by ICT applications hosted by Learning Management Systems. 
Saudi female students are strictly prohibited from using smartphones during class for fear that unauthorized pictures will be taken and distributed to other individuals outside of their immediate family. However, when not in school, Saudi women spend most of their time at home with ready access to computers and other mobile devices. Classroom activities could be designed to allow for Saudi female students to communicate about and collaborate on assignments with other female students from their homes, creating similar learning opportunities to those available to their male counterparts.

The use of ICT applications, particularly social media tools, is a fairly recent phenomenon in both Saudi Arabia and the United States. However, these ICT applications have the potential to actively engage students in effective learning through the use of text based and multi-media course content that can be accessed at anytime and at any place. Additionally, social media applications when organized using Learning Management Systems can provide seamless access to educational resources to students who would not otherwise have access to higher education programs. Although mobile learning research, particularly with respect to smartphones and tablets, is fairly recent, results from this study and others suggest that faculty should consider how they could use the wide array of ICT applications to develop course materials that are readily accessible to students regardless of their location. Curriculum development designed with respect to mobile technologies is vitally important to increase opportunities for students to learn as university students' use of mobile technologies, paired with social media and ICT other applications, continues to grow. 
REFERENCES CITED 
Abeysekera, L., \& Dawson, P. (2014). Motivation and cognitive load in the flipped classroom: definition, rationale and a call for research. Retrieved from http://www.tandfonline.com/doi/abs/10.1080/07294360.2014.934336\#.VPPYdrV OWUk

Ajjan, H, \& Hartshorne, R. (2008). Investigating Faculty Decisions to Adopt Web 2.0 Technologies: Theory and Empirical Tests. Internet and Higher Education. Retrieved from http://eric.ed.gov/?id=EJ807333

Al-Jarf, R. (2007) E-integration challenges for rectors and deans in higher education. Computer and Advanced Technology in Education Conference Proceedings. ACTA Press. Canada.

Al-Khalifa, H.S. (2010). A first step in evaluating the usability of JUSUR learning management system. Paper presented at the $3{ }^{\text {rd }}$ Annual Forum on e-learning Excellence in the Middle East 2010: Bringing Global Quality to Local Context. February $1^{\text {st }}-3^{\text {rd }}$, Dubai, UAE.

Al-Khalifa, S. H. (2009, October). The State of distance Education in Saudi Arabia. eLearn Magazine. Retrieved from http://elearnmag.acm.org/archive.cfm?aid=1642193

Al-Maliki, S. (2013). Information and Communication Technology (ICT) Investment in the Kingdom of Saudi Arabia: Assessing Strengths and Weaknesses. Retrieved from http://www.ibimapublishing.com/journals/JOKM/2013/450838/450838.pdf

Al Mulhem, A. (2013). Developing an E-Learning Training Package for Academic Staff in One University in Saudi Arabia. British Library Online e-thesis Online Service.

Al Mulhem, A. (2013). Common Barriers to E-Learning Implementation in Saudi Higher Education Sector: A Review of Literature. University of Plymouth, UK.

Al shaer, A. I. (2007). Education for all programmes in the Kingdom of Saudi Arabia. [United Nation Educational Scientific and Cultural Organization]

Alshari, A.M. (2012). E-learning in Saudi Arabia: 'To E or not to E, that is the question' Family Community Med, 17 (3): 147-150.

Alsiri, M.J., Mahmud, R.B., Bakar, K.A., Ayub, A.F., \& Ayub, A.F.M. (2012). Factors influencing the use of learning management systems in Saudi Arabian higher education: A theoretical framework. Higher Education Studies, 2 (2), 125-137. 
Al-Shawi, A., \& Al-Wabil, A. (2013). Internet Usage by Faculty in Saudi Higher Education. International Journal of Computer Science Issue, 10, (3). Retrieved from http://ijcsi.org/papers/IJCSI-10-3-2-81-87.pdf

Alebaikan, R. \& Troudi, S. (2008). Blended learning in Saudi universities: challenges and perspectives. University of Exeter, UK. Francis CALT_A_466270.sgm (Received 29 November 2008; final version received 5 July 2009)

Alharbi, A. (2013). E-learning in the KSA: A taxonomy of learning methods in Saudi Arabia. Retrieved from http://aut.researchgateway.ac.nz/handle/10292/7225

Alhareth, Y. McBride, N. Prior, M.,Leigh, M. \& Flick, C. (2013). Saudi Women and E-learning. Retrieved from http://conference.pixelonline.net/foe2013/common/download/Paper_pdf/142-ELE15-FP-AlharethFOE2013.pdf.

Aljabre, A. (2012). An Exploration of Distance Learning in Saudi Arabian Universities: Current Practices and Future Possibilities. International Journal of Business, Humanities and Technology, 2 (132). Retrieved from http://www.ijbhtnet.com/journals/Vol_2_No_2_March_2012/17.pdf

Alkhalaf, S., Drew, S., AlGhamdi, R., Alfarraj, O. (2012). E-learning system on higher education institutions in KSA: attitudes and perceptions of faculty members. Procedia - Social and Behavioral Sciences, 47, 1199-1205.

Allen, E., \& Seaman, J. (2013, January). Changing Course Ten Years of Tracking Online Education in the United States. Retrieved from http://onlinelearningsurvey.com/reports/changingcourse.pdf

Allen, E., \& Seaman, J. (2011, November). Going the Distance: Online Education in the United States. Retrieved from http://www.onlinelearningsurvey.com/reports/goingthedistance.pdf

Altawil, A.N. (2012) The Perceptions Of Saudi Student On Using Fully Online Courses At University Level. Retrieved from http://www.academia.edu/8616172/The_perceptions_of_Saudi_students_on_usin g_fully_online_courses_at_university_level.

Alenzi, A.M. (2012). Faculty members perceptions of e-learning in the Kingdom of Saudi Arabia (KSA) (Unpublished doctoral dissertation). Texas Tech University, Lubbock, TX. 
Andronie, M. \& Andronie, M. (2014). Information and Communication Technologies Used for Education and Training. Contemporary Readings in Law and Social Justice, 6(1). Retrieved from http://www.ceeol.com/aspx/issuedetails.aspx?issueid=b91b0cfe-b133-48c1-a14b78d4f2725472\&articleId=b316175e-fb53-401a-a803-494ca31ad939

Baqutayan, S. M. (2011). Issues in the Implementation of Science and Technology Education in Saudi Arabia. International Journal of Applied Science and Technology, 1 (5), 165.

Bingimlas, K.A. (2009). Barriers to the successful integration of ICT in teaching and learning environments: A review of the literature. Eurasia Journal of Mathematics, Science and Technology Education, 5 (3), 235-245.

Berrett, D. (2015) How 'Flipping' the Classroom Can Improve the Traditional Lecture. The Chronicle of Higher Education. Retrieved from http://chronicle.com/article/How-Flipping-the-Classroom/130857/

Bishop, J. L. (2013) The Flipped Classroom: A Survey of the Research. Retrieved from http://www.asee.org/public/conferences/20/papers/6219/view

Blankenship, M. (2010). How social media can and should impact a higher education. Retrieved from www.wdhstore.com/hispanic/data/pdf/nov29-howsocial.pdf

Brame, C. J. (2013). Flipping the classroom. Retrieved from http://cft.vanderbilt.edu/guides-sub-pages/flipping-the-classroom/.

Browne, M. W., \& Cudek, R. (1993). Alternative ways of assessing model ®t. In K. A. Bollen \& J. S. Long (Eds.), Testing structural equation models (pp. 136-162). Newbury Park, CA: Sage Publications.

Jones, A. (2004) A review of the literature on barriers to the uptake of ICT by teachers: British Communications and Technology Agency (Becta). Retrieved from http://dera.ioe.ac.uk/view/organisations/becta.html

Brown, L. Instructor perceptions of teaching online at Montana State University, Montana State University, Bozeman, Montana, Nov. 27, 2013

Burns, M. (2010). How to Help Teachers Use Technology in the Classroom. Elearn Magazine. Retrieved from http://elearnmag.acm.org/featured.cfm?aid=1865476

Cleaver, S. (2014). Technology in the classroom: Helpful or Harmful? Retrieved from http://www.education.com/magazine/article/effective-technology-teaching-child/ 
Cramer, M., \& Hayes, G. (2010). Acceptable use of technology in schools: Risks, policies, and promises. IEEE Pervasive Computing, 9 (3), 37-44.

Daher, T., \& Lazarevic, B. (2014). Emerging instructional technologies: Exploring the extent of faculty use of web 2.0 tools at a midwestern community college. Tech Trends, 58 (6). Retrieved from http://link.springer.com/article/10.1007/s11528014-0802-1

Davis, F. D. (1989), "Perceived usefulness, perceived ease of use, and user acceptance of information technology." MIS Quarterly, 13 (3), 319-340.

Davis, F.D. (1993). User acceptance of information technology: system characteristics, user perceptions and behavioral impacts. International Journal of Man-Machine Studies, 38, 475-487

Desire2Learn. (n.d.). Retrieved December 18, 2014, from http://en.wikipedia.org/wiki/Desire2Learn.

Diamantopoulos, A. \& Siguaw, J.A. (2009). Introducing LISREL. Thousand Oaks, CA: Sage.

Fishbein, M. \& Ajzen, I. (1975). Belief, attitude, intention and behavior: An introduction to theory and research. Addison-Wesley, Reading, MA

Gannam, J. (2011). Social media in the Arab world: Leading to the uprisings of 2011. Center for International Media Assistance. Washington, DC.

Gay, L.R., Mills, G. E., Airasian, P. (2012). Educational research: Competencies for analysis and applications. Boston, MA: Pearson.

Gikas, J. \& Grant, M. M. (2013). Mobile computing devices in higher education: Student perspectives on learning with cellphones, smartphones \& social media. Retrieved from http:/www.sciencedirect.com/science/article/pii/S1096751613000262

Goodwin, B. \& Miller K. (2013). Evidence on Flipped Classrooms Is Still Coming In. Educational Leadership, 70(6). Retrieved from http://www.educationalleadershipdigital.com/educationalleadership/201303/?pg=80\#pg80.

Hamdan, A (2014). The Reciprocal and Correlative Relationship Between Learning Culture and Online Education: A Case from Saudi Arabia. The International Review ofResearch in Open and Distributed Learning, Vol. 15, No.1. Retrieved from http://www.irrodl.org/index.php/irrodl/article/view/1408 
Huang, R., Deggs, D., Jabor, M., Machtmes, K. (2011). Faculty Online Technology Adoption. The Role of Management Support and Organizational Climate. Online Journal of Distance Learning Administration, XIV(II). Retrieved from http://www.westga.edu/ distance/ojdla/summer142/huang_142.html

Hislop, G.W., \& Ellis, H.J.C. (2004). A study of faculty effort in online teaching. The Internet and Higher Education, 7(1). Retrieved from http://eric.ed.gov/?q=A+study+of+faculty+effort+in+online+teaching\&id=EJ803 708

Hooker, C. (2014). How Technology Trends Have Influenced the Classroom. Retrieved from: http://blogs.kqed.org/mindshift/2014/03/how-real-world-technology-usehas-inflitrated-change-classrooms/

Jaschik, S. \& Lederman, D, ed. (2014) The 2014 Inside Higher Ed Survey of Faculty Attitudes on Technology. Inside Higher Ed. Retrieved from www.insidehighered.com.

Johnson, T., Wisniewski, M.A., Kuhlemeyer, G., Isaacs, G. \& Kryzkowski, J. (2008). Technology adoption in higher education: Overcoming anxiety through faculty bootcamp. Journal of Asynchronous Learning Networks, 16, (2), 63-72.

Krueger, P. J. (2001). Reflections of Beginning Music Teachers. Music Educators Journal, 88(3).

Mayes, R., Luebeck, J., Ku, H. Akarasriworn, C., \& Korkmaz, O. (2011). Themes and Strategies for Transformative Online Instruction. The Quarterly Review of Distance Education, 12 (3). Retrieved from http://www.readperiodicals.com/201110/2581146771.html

McKeown, K. (2012, March 13). Can Online Learning Reproduce the Full College Experience? The Heritage Foundation. Retrieved from http://www.heritage.org/research/reports/2012/03/can-online-learning-reproducethe-full-college-experience? $\mathrm{ac}=1$.

Meadowcroft, B. (2006). The impact of information technology on work and society. Retrieved 24/9/2011 from www.m-w.com/cgi-bin/netdict?society

Mejiuni, O. \& Obilade, O. (2006).The dialectics of poverty,educational opportunities, and ICTs, in A. Oduaran \& H.S. Bhola (Eds.). Widening access to education as social justice (pp. 139-148). The Netherlands: Springer. 
Moran, M., Seaman, J. and Tinti-Kane, H. (2011). Teaching, learning, and sharing: How today's higher education faculty use social media. The Educational Resources Information Center. Retrieved from http://eric.ed.gov/?id=ED535130.

Payette, D. L. \& Verreault, D. (2007). Teaching methods and technologies: Aggregated faculty analysis, conclusions and recommendations phase IV. Journal of College Teaching and Learning, 4 (6), 43-60.

Piskurich G.M. (2003). Preparing Learners for e-Learning. San Francisco: Wiley.

Powers, L, Alhussain, R., Averbeck, C., \& Warner, A. (2012). Perspectives on distance education and social media. The Education Resources Information Center, 13. Retrieved from http://eric.ed.gov/?q=source\%3a\%22Quarterly+Review + of + Distance+Education $\% 22 \& f f 1=$ pubOpinion + Papers\&id=EJ1005854

Protalinski, E. (2014). Facebook Passes 1.23 Billion Monthly Active Users. The Next Web. Retrieved from http://thenextweb.com/facebook/2014/01/29/facebookpasses-1-23-billion-monthly-active-users-945-million-mobile-users-757-milliondaily-users/

Radicati, S. (2011). Email Statistics Report, 2011-2015. Retrieved from http://www.radicati.com/wp/wp-content/uploads/2011/05/Email-Statistics-Report2011-2015-Executive-Summary.pdf

Roblyer, M.D., McDaniel, M., Webb, M., Herman, J. \& Witty, J.V. (2010). Findings on Facebook in higher education: A comparison of college faculty and student uses and perceptions of social networking sites. Internet and Higher Education, 13(3). Retrieved from http://eric.ed.gov/?id=EJ886995

Rowley, J. (1999). The Good Mentor: What It Takes To Be Effective. Educational Leadership 56(8). Retrieved from http://www.edutopia.org/good-mentor

Saudi Ministry of Higher Education Deputyship for Planning \& Information General Department for Planning \& Statistics (2010). Women in Higher Education Saudi Initiatives \& Achievements. Retrieved from http://www.mohe.gov.sa/ar/Ministry/Deputy-Ministry-for-Planning-andInformation-affairs/The-General-Administration-ofPlanning/Documents/women_in_higher_edu.pdf

Schunk, D. (2011). Learning Theories: An Educational Perspective (6th ed.). Pearson.

Siemens, G. (2004). Connectivism: A Learning Theory for the Digital Age. eLearnspace. Retrieved from http://www.elearnspace.org/Articles/connectivism.htm 
Smith, M. (2014). Strategies That Work. One school technology learder's winning strategies for staff development in technology integration. Retrieved from: http://www.scholastic.com/browse/article.jsp?id=60

Starr, L. (2012). Encouraging Teacher Technology Use. Education World. Retrieved from http://www.educationworld.com/a_tech/tech159.shtml.

Strayer, J. (2011). The Flipped Classroom: Turning the Traditional Classroom on its Head. Retrieved from http://www.knewton.com/flipped-classroom/

Tabata, L.N. \& Johnsrud, L.K. (2008). The impact of faculty attitudes toward technology, distance education and innovation, Research in Higher Education, 49, 625-646.

Usluel, Y., \& Mazman, S. (2009, January). Adoption of Web 2.0 tools in distance education. Research Gate. Retrieved from http://www.researchgate.net/publication/222944678_Adoption_of_Web_2.0_tool s_in_distance_education

VanDoorn, G. \& Edlund A. (2013). Face to Facebook: Social media and the learning and teaching potential of symmetrical, synchronous communication. Journal of University Teaching \& Learning Practice, 10(1). Retrieved from http://files.eric.ed.gov/fulltext/EJ1005279.pdf

Vanwynsberghe, H, \& Verdegem, P. (2013). Integrating social media in education. CLCWeb: Comparative Literature and Culture, 15(3). Retrieved from http://docs.lib.purdue.edu/clcweb/vol15/iss3/10/

Venkatesh, V., Morris, M.G., Davis, F.D., and Davis, G.B. (2003). User Acceptance of Information Technology: Toward a Unified View. MIS Quarterly, 27: 425478.

Wanstreet, C. (2006). Interaction in Online Learning Environments: A Review of the Literature. Quarterly Review of Distance Education, 7 (4). Retrieved from http://www.editlib.org/p/106711/

Ward, M., Peters, G., \& Shelley, K. (2010). Student and Faculty Perceptions of the Quality of Online Learning Experiences. International Review of Research in Open and Distance Learning, 11(3). Retrieved from http://eric.ed.gov/?id=EJ913860

Wasilik, O., \& Bolliger, D.U. (2009). Faculty satisfaction in the online environment: An institutional study. The Internet and Higher Education, 12. Retrieved from http://eric.ed.gov/?id=EJ861737 
What Is Successful Technology Integration? (2007, November 5) Edutopia. Retrieved from: http://www.edutopia.org/technology-integration-guide-description.

Wilson, C. (2012) Making Connections: Higher Education Meets Social Media, Change: The Magazine of Higher Learning. Retrieved from http://www.changemag.org/Archives/Back\%20Issues/2013/JulyAugust $\% 202013 /$ making-connections-abstract.html 
APPENDICES 
APPENDIX A

ONLINE SURVEY ENGLISH 
Dear Participant,

My name is Mabark Alshahri and I am a doctoral candidate at Montana State University. I am inviting you to participate in a study about faculty's use of electronic tools for communication with students and for instruction. This consent form will provide the information that you need in order to make an informed decision about whether or not you would like to participate in this survey. Answering these questions should take no more than 5 to 10 minutes of your time. Once you have obtained sufficient information in order to provide informed consent, please choose whether or not you wish to participate in this study.

\section{SUBJECT CONSENT FORM FOR PARTICIPATION IN HUMAN RESEARCH AT MONTANA STATE UNIVERSITY}

\section{Project Title: A Comparison of Saudi and United States Faculty Use of Information and Communication Technology Tools}

Purpose of the research study: You are being asked to participate in a research study to investigate the frequency of use and the types of electronic tools Saudi and United States faculty use for communicating with students and for instruction. In addition, this study will also examine faculty perceptions of electronic tools ease of use and usefulness.

Voluntary participation: Your participation in this research is completely voluntary and you can choose not to answer any questions you do not want to answer and/or you can stop at any time.

Procedures involved: This study consists of a survey administered online. The survey asks you to indicate your use, ease of use and usefulness of various electronic tools. In addition, there are four open-ended questions that will allow you to provide more detailed responses about your use of electronic tools for communicating with students and for instruction. You may choose not to answer any questions you do not want to answer and/or you can stop answering survey questions at any time.

The responses you provide are anonymous and will not be linked to any personal information. No identifying information will be collected from this study. Email addresses form the electronic survey will be stripped from the data file prior to analysis to ensure respondents' anonymity and confidentiality. Only group results will be reported for this research project.

Risks and Benefits: If you feel uncomfortable about any of the questions, you may choose to leave items blank or to terminate your participation in the survey. The study is of no benefit to you.

Right to withdraw from the study: You have the right to withdraw from participating in this survey at any time.

Source of Funding: NA

Cost to Subject: None

Confidentiality: There will be no identifying information collected, as the survey is anonymous.

Whom to contact if you have questions about the study

If you have questions about this study, please contact Mabark Alshahri at (406) 5809944or at mabark@me.com. Additional questions about the rights of human subjects 
can be answered by the Chairman of the Institutional Review Board, Mark Quinn at (406) 994-4707 or at mquinn@montana.edu

AUTHORIZATION: I have read the above and understand the discomforts, inconvenience and risk of this study.if any By accessing the survey link below, I agree to participate in this research. I understand that I may later refuse to participate, and that I may withdraw from the study at any time. I have received a copy of this consent form for my own records.

If you agree to participate, please continue with the survey. If you choose not to participate or you are not a university professor/instructor, please close your browser now to exit the survey.

\section{A Cross Cultural Comparison of Saudi and United States Faculty's Use of Electronic Tools for Instruction and Communicating with Student}

\section{Gender.}

\section{Male}

Female

Please use the slider bar below to indicate your age.

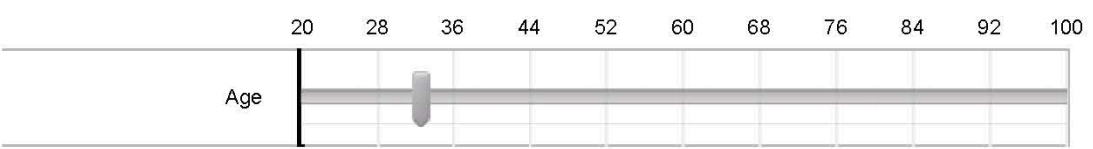

Please use the slider bar below to indicate many years of experience do you have teaching in higher education? 


\begin{tabular}{l|llllllllllll} 
Online Survey Software I Qualtries Survey Solutions & \\
Years of Experience & 11 & 11 & 21 & 31 & 41 & 51 & 60 & 70 & 80 & 90 & 100 \\
\hline
\end{tabular}

Have you ever taught all or part of a course online?

Yes

No

How many hours per week do you use the electronic tools for communicating with your students and instruction in and outside of the classroom. For example, how often do you use these electronic tools weekly for communicating with students, helping students with their assignments, and answering

questions. Please estimate the number of hours using the slider bar below

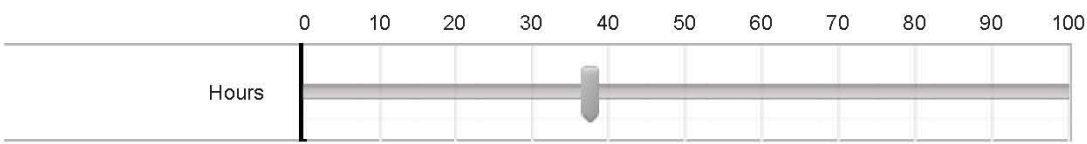

Have you used any Learning Management System (i.e. online classroom) for communicating with and/or teaching your students? Select any that apply.

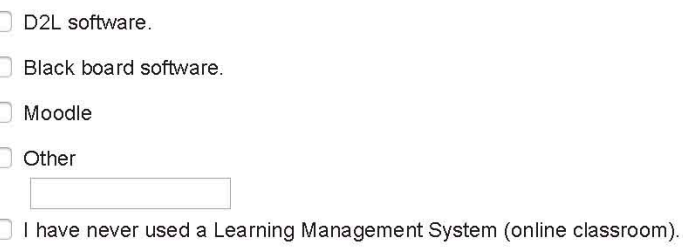

Please rate how often you use the following list of electronic tools for learning and for communicating with your students for instructional purposes. Please use one of the following descriptors for each electronic tool: "Never (Not at all), Rarely (less than weekly), Sometimes (multiple times a week but not daily), All of the Time (Daily), Always (Multiple times a day)" for each question? 


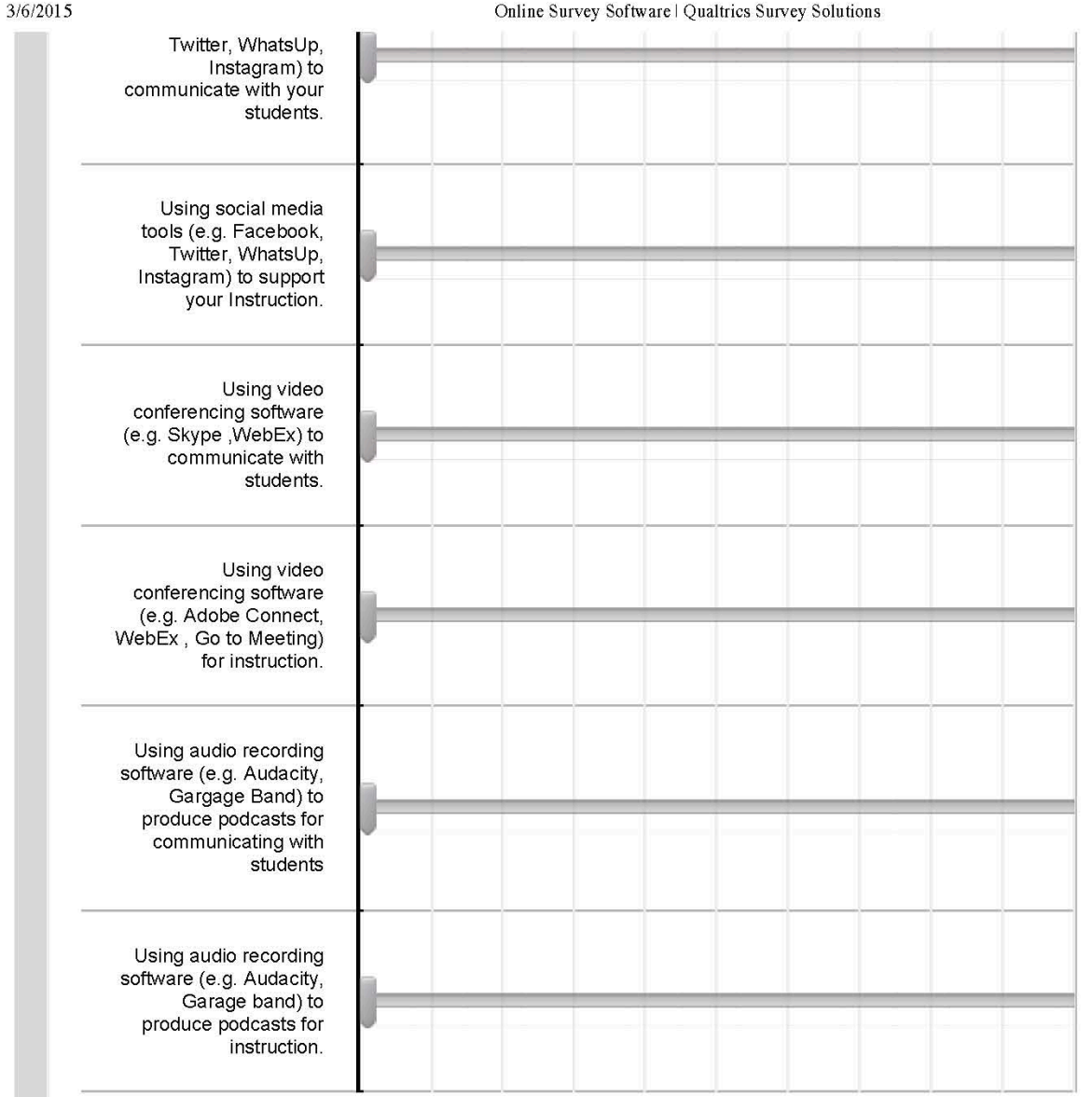

Please describe below any other electronic tools that you use with students and how often you use them. Rarely (less than weekly), Sometimes (multiple times a week but not daily), All of the Time (Daily), Always (Multiple times a day)"

Please describe why you use the above electronic tools "Often" or "Always" for communicating with students and instruction. 


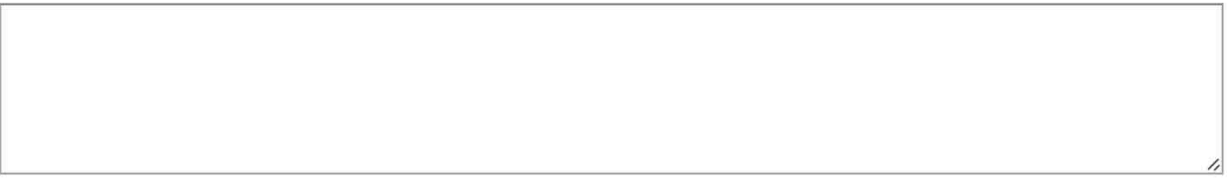

Please describe why you "don't use or seldom use" the selected electronic tools for communicating with students and instruction.

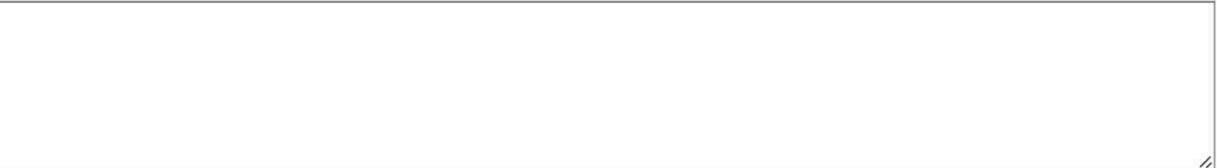

Please rate your perceptions of the following statements about the electronic tools ease of use, using the following descriptors: Strongly Agree, Agree, Neither Agree or Disagree, Disagree, Strongly Disagree. Electronic tools for this question are defined as social media tools (ex. Facebook, Twitter), productivity software (ex. Word, Excel, Powerpoint), video conferencing software (ex. Skype) and other electronic technologies that can be used for communicating with students and for instruction.

\begin{tabular}{|c|c|c|c|c|c|}
\hline & $\begin{array}{l}\text { Strongly } \\
\text { Disagree }\end{array}$ & Disagree & $\begin{array}{l}\text { Neither Agree } \\
\text { nor Disagree }\end{array}$ & Agree & Strongly Agree \\
\hline $\begin{array}{l}\text { Using social media tools (e.g. Facebook, } \\
\text { Twitter) for communicating with students } \\
\text { and instruction is easy. }\end{array}$ & & & & & \\
\hline $\begin{array}{l}\text { Using productivity software (e.g. } \\
\text { PowerPoint, Excel, Word) for } \\
\text { communicating with students and } \\
\text { instruction is easy. }\end{array}$ & & & & & \\
\hline $\begin{array}{l}\text { Using Web conferencing software (e.g. } \\
\text { Skype, Webex) for communicating with } \\
\text { students and instruction is easy. }\end{array}$ & & & & & \\
\hline $\begin{array}{l}\text { Using courseroom management systems } \\
\text { (e.g. Blackboard, D2L, Moodle) for } \\
\text { communicating with students and } \\
\text { instruction is easy. }\end{array}$ & $C$ & & & & \\
\hline
\end{tabular}

Please rate the statements below regarding your perceptions of the value of using electronic tools by choosing the following descriptors: Strongly Agree, Agree, Neither Agree or Disagree, Disagree, Strongly Disagree. Electronic tools for this question are defined as social media tools (ex. Facebook, Twitter), productivity software (ex. Word, Excel, Powerpoint), video conferencing software (ex. Skype) and other electronic technologies that can be used for communicating with students and for instruction. 


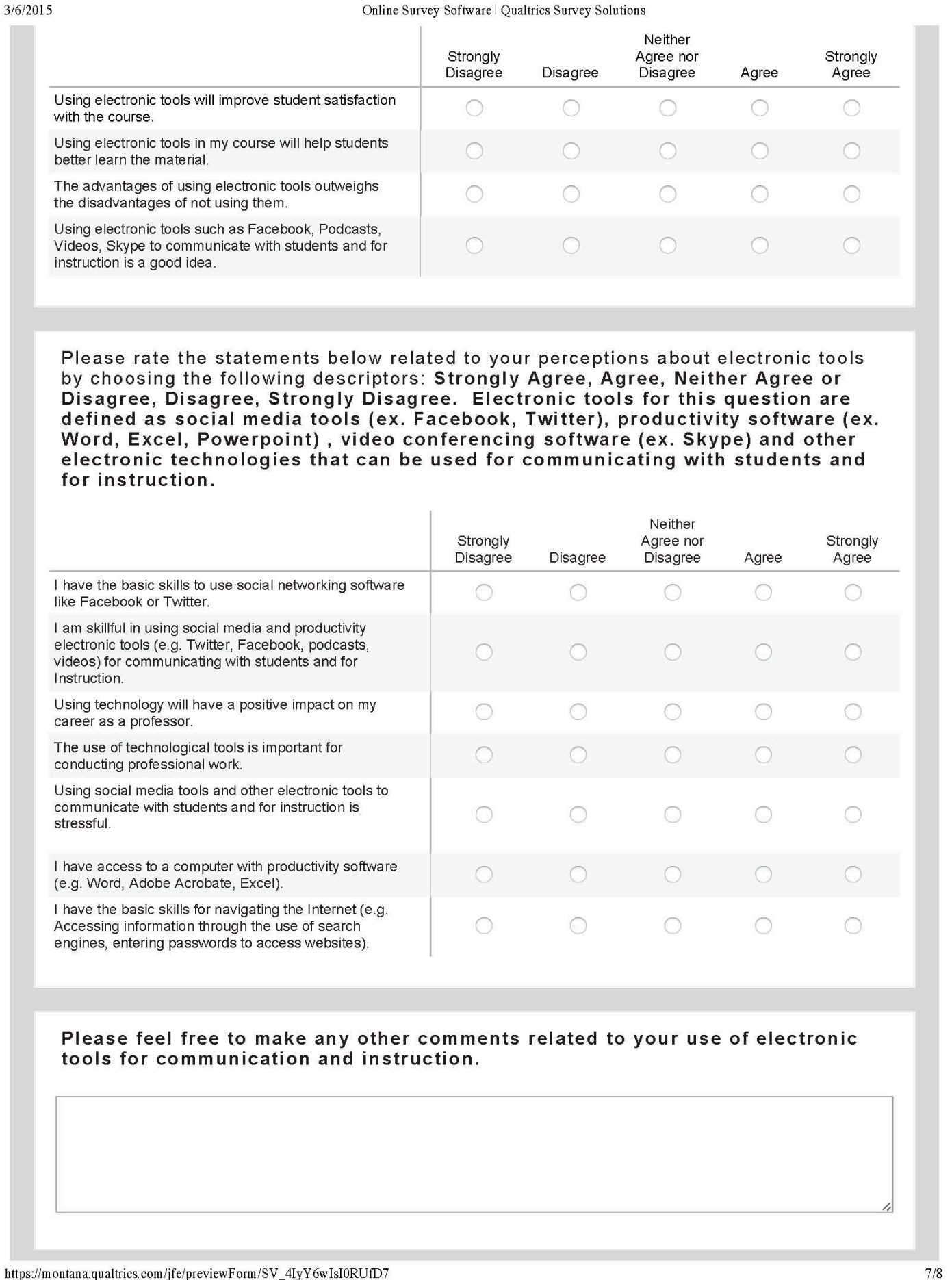


APPENDIX B

ONLINE SURVEY ARABIC 


\title{
$\left(\frac{10}{2}\right.$
}

Onthe Survey Softwatel altics Survey Solutions

(1)

\begin{abstract}
(2)
\end{abstract}

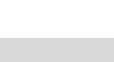




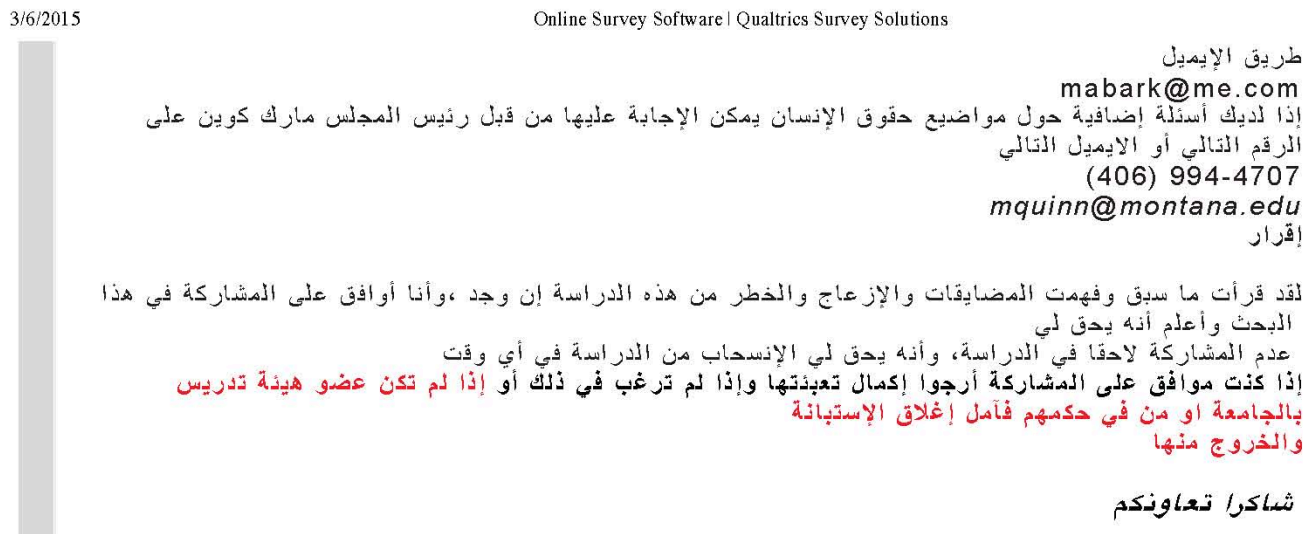

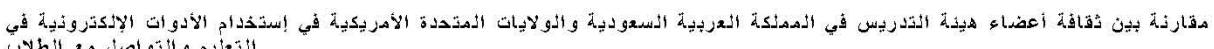

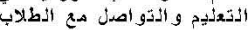

\section{Gender.}

Male نئ

Female أنثى

Please use the slider bar below to indicate your age.

دن فضذلك ثم بثدريك الشدريحة في الدمقياس أدناه لتحدد كم عدرك

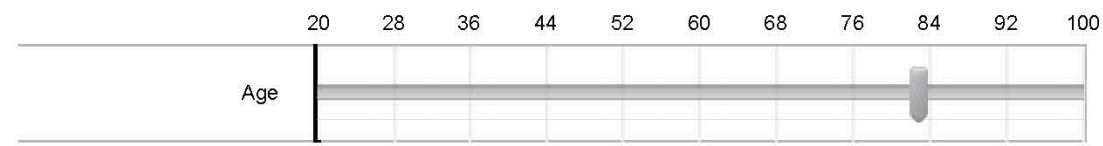

Please use the slider bar below to indicate how many years of experience do you have teaching in higher education?

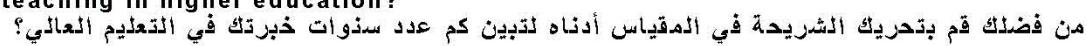

https://m ontana.qualtrics.com/je/previewF orm/SV_6njsVneFrg2S4PH 


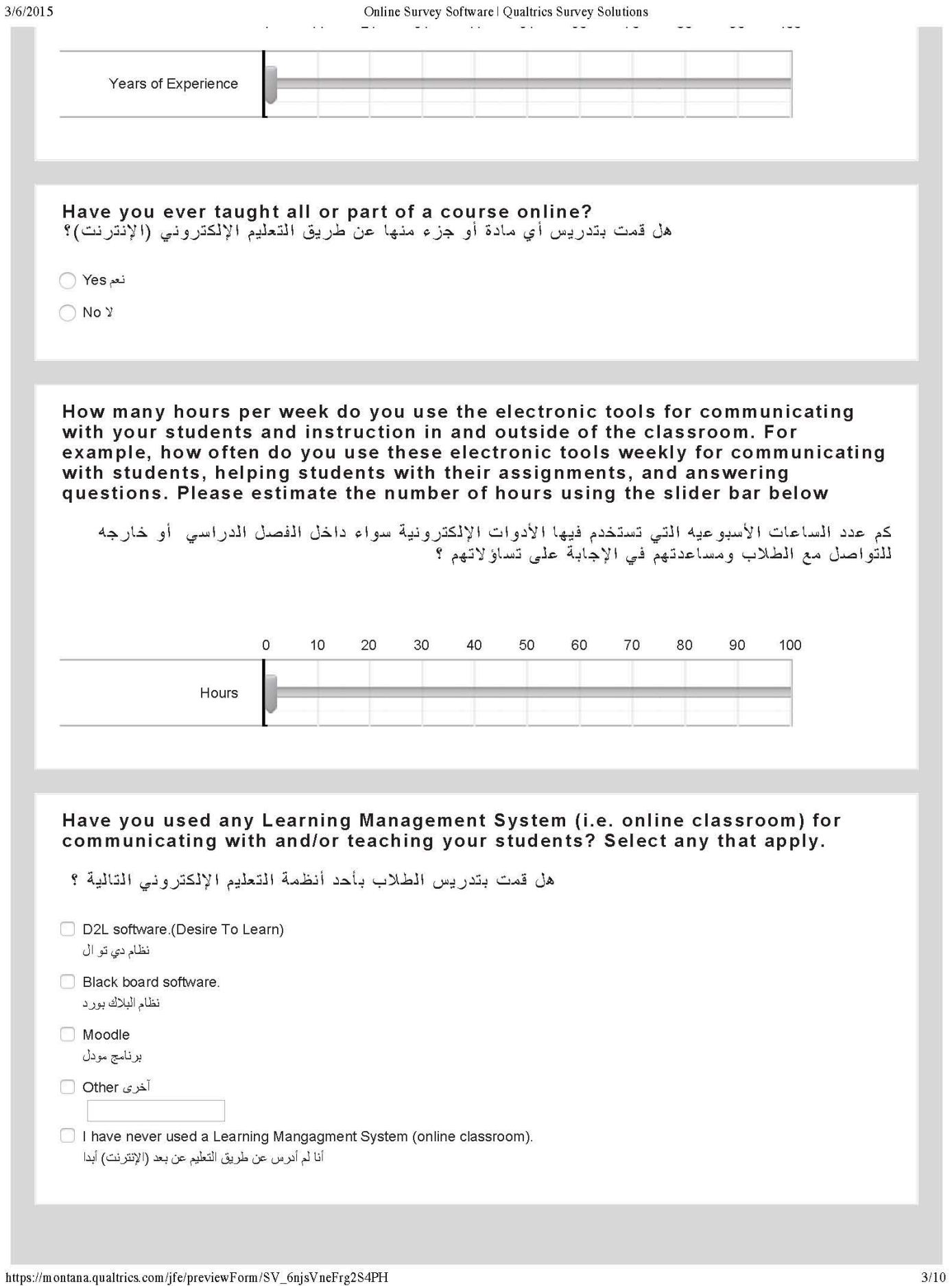


Please rate how often you use the following list of electronic tools for learning and for communicating with your students for instructional purposes. Please use one of the following descriptors for each electronic tool: "Never (Not at all), Rarely (less than weekly), Sometimes (multiple times a week but not daily), All of the Time (Daily), Always (Multiple times a day)" for each question?

$$
\begin{aligned}
& \text { من فضداك اختز الدصطلح المذاسب في الجدول التالي لتبين معدن إستخدامك ليكدو ات و الذبر امج الإلكترو نية }
\end{aligned}
$$

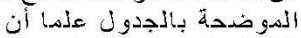

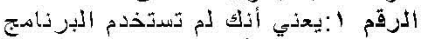

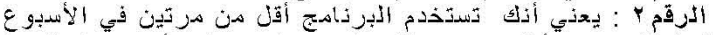

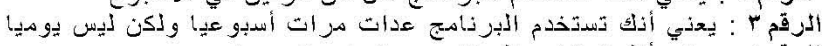

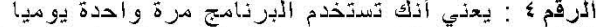

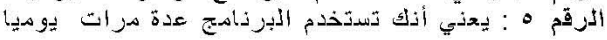

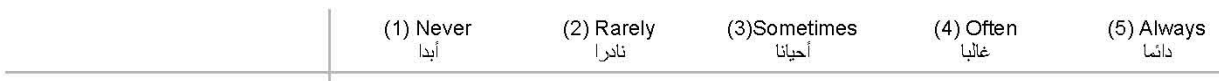

Social media tools (e.g.

Facebook, Twitter, WhatsUp,

Instagram)

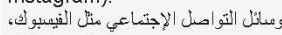

تويثز، وتشاب، انثيثقرام

Video conferencing software

(e.g. Skype, WebEx, Go to

Meeting).

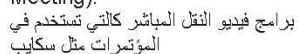

Word Processing (ex Word)

برامج تحريز النصوص مثال الؤورد

Spreadsheets (e.g. Excel,

Access)

جداون الييانات مثل الاكسن

Presentations (e.g

Powerpoint).

بر امج المعروض مئل الباوربوينت

Videos (e.g. Youtube)

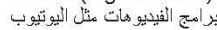

Audio Recordings to create

Podcasts (e.g. Audacity,

Garage Band).

أبنرامج التي ثنتخدم في تشجيل المبواد

صوتياً متل كراج باندان

Screencasts (ex. Camtasia).

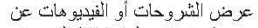

طريق تسجئها بشأشئة الكبيوترن

Photos

الصور

Google Documents

وتائق ملفات قوق تصل

Portable Document Files (e.g.

Abode PDF)

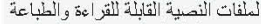

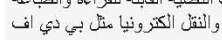

Instructor Created Webpages

(e.g. Frontpage,

Dreamweaver)

https://m ontana.qualtrics.com/je/previewF orm/SV_6njsVneFrg2S4PH 


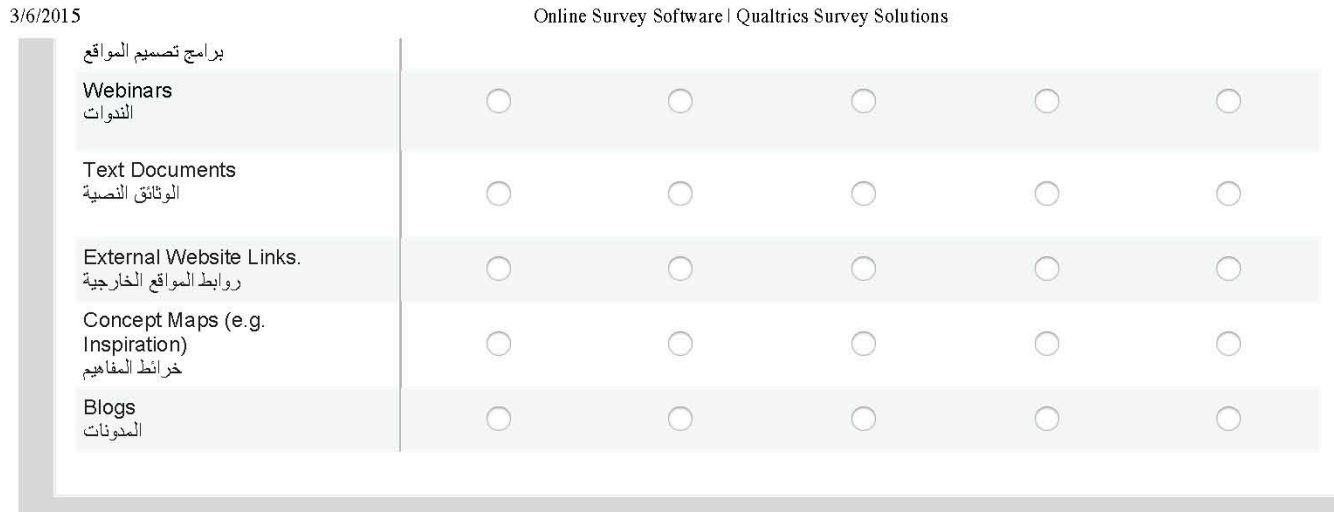

Please use the slider bars below to more precisely estimate how many hours per week you use the electronic tools listed below for communicating with students and for instruction.

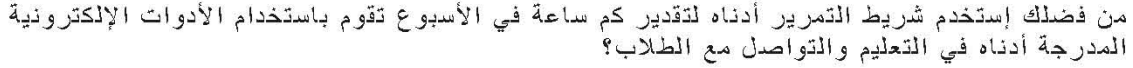

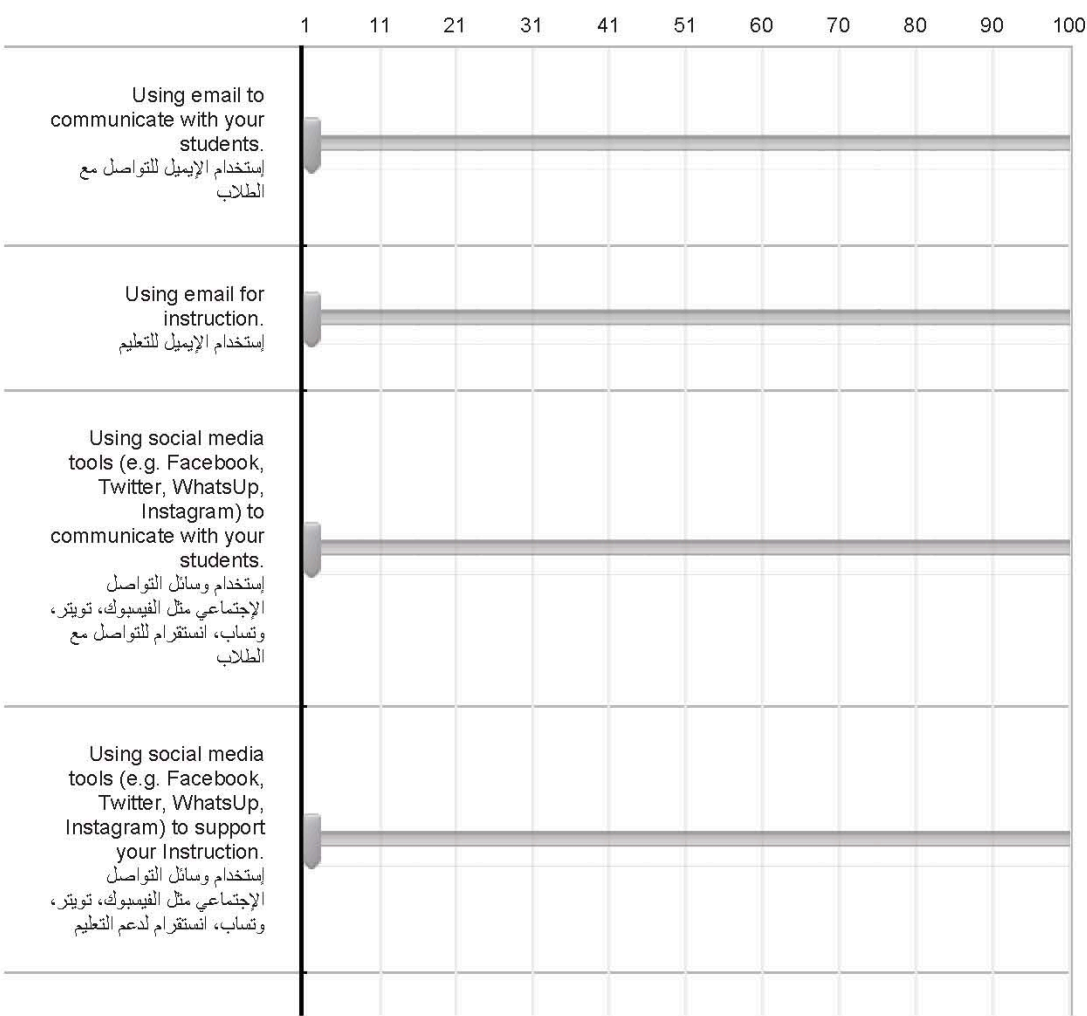

https://m ontana.qualtrics.com/je/previewForm/SV_6njsVneFrg2S4PH 


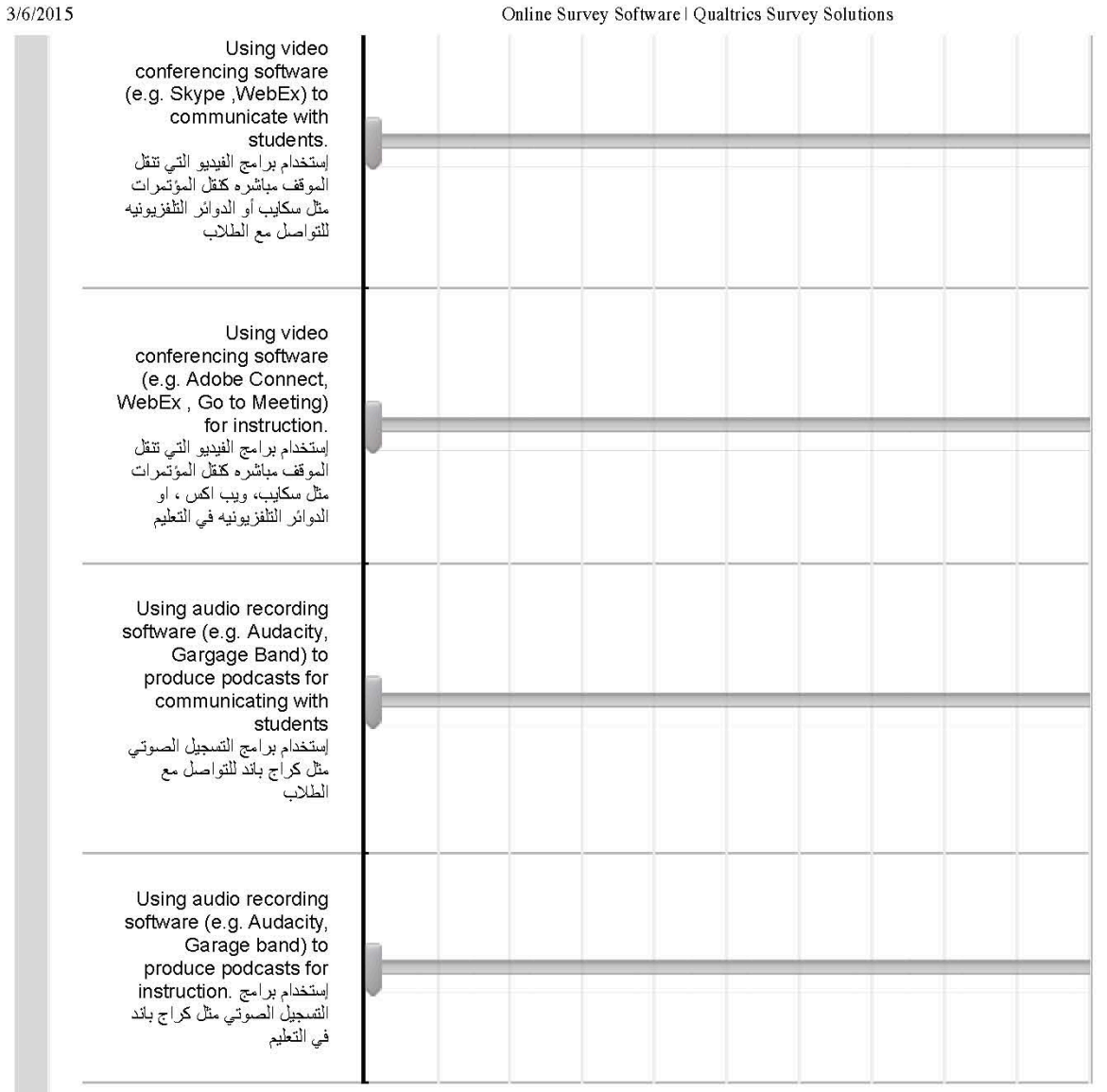

Please describe below any other electronic tools that you use with students and how often you use them.

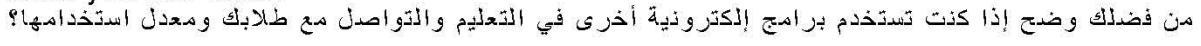

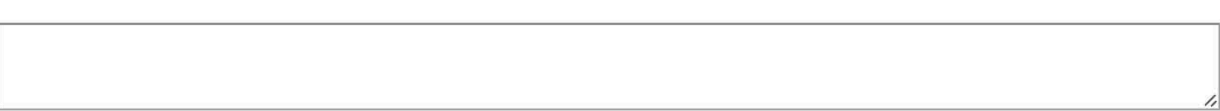

Please describe why you use the above electronic tools "Often" or "Always" for communicating with students and instruction.

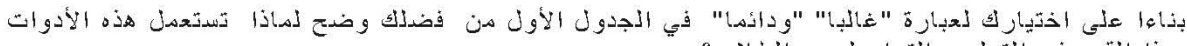

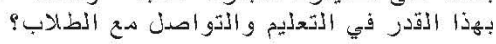

https://m ontana.qualtrics.com/jfe/previewForm/SV_6njsVneFrg2S4PH 
111

$3 / 6 / 2015$

Online Survey Software / Qualtrics Survey Solutions

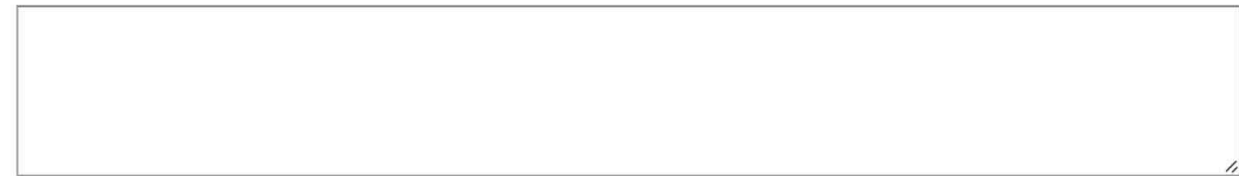

Please describe why you "don't use or seldom use" the selected electronic tools for communicating with students and instruction.

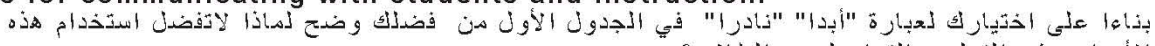

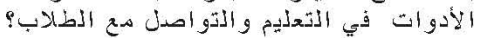

Please rate your perceptions of the following statements about the electronic tools' ease of use, using the following descriptors: Strongly Agree, Agree, Neither Agree or Disagree, Disagree, Strongly Disagree. Electronic tools for this question are defined as social media tools (ex. Facebook, Twitter), productivity software (ex. Word, Excel, Powerpoint), video conferencing software (ex. Skype) and other electronic technologies that can be used for communicating with students and for instruction.

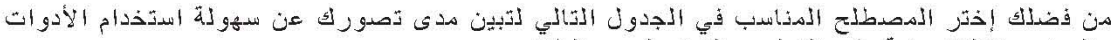

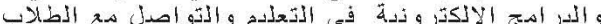

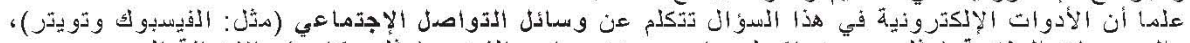

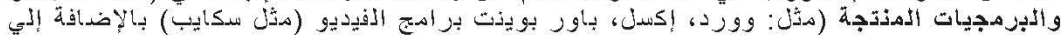

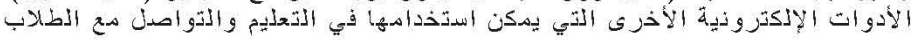

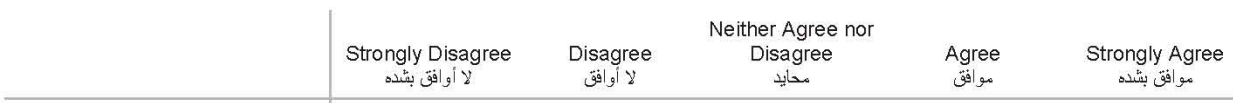

Using social media tools (e.g.

Facebook, Twitter) for

communicating with students

and instruction is easy.

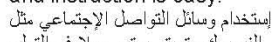

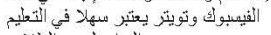

والثتواصن مع أنطلانب

Using productivity software

(e.g. Powerpoint, Excel, Word)

for communicating with

students and instruction is

easy.

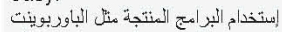

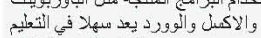

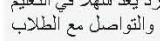

Using Web conferencing

software (e.g. Skype, Webex)

https://m ontana.qualtrics.com/jfe/previewF orm/SV_6njsVneFrg2S4PH 
112

$3 / 6 / 2015$

Online Survey Software | Qualtrics Survey Solutions

for communicating with students and instruction is easy.

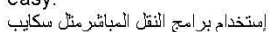

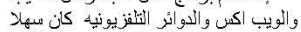

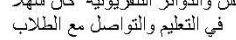

Using electronic classrooms (e.g. Blackboard, D2L,

Moodle) for communicating with students and instruction is easy.

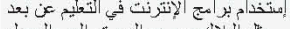

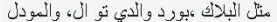

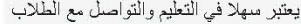

Please rate the statements below regarding your perceptions of the value of using electronic tools by choosing the following descriptors: Strongly Agree, Agree, Neither Agree or Disagree, Disagree, Strongly Disagree. Electronic tools for this question are defined as social media tools (ex. Facebook, Twitter), productivity software (ex. Word, Excel, Powerpoint), video conferencing software (ex. Skype) and other electronic technologies that can be used for communicating with students and for instruction.

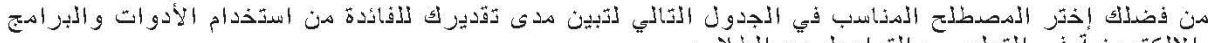

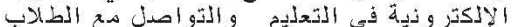

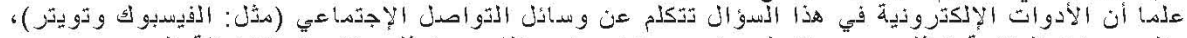

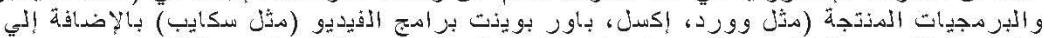

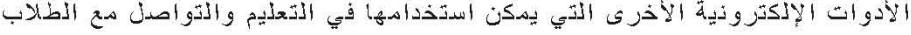

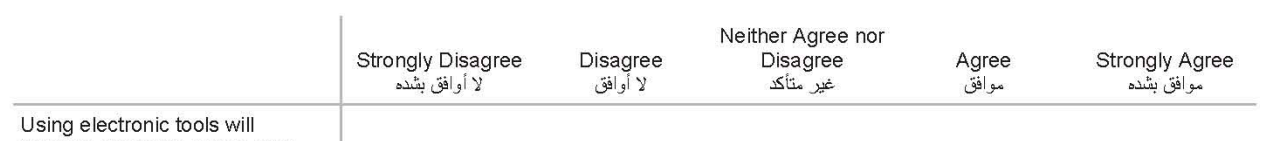

improve student's satisfaction

with the course.

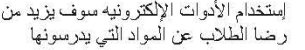

Using electronic tools in my

course will help students better learn the material.

إستخدام الأدو ات الإلكثرونية في مادثي صوف بحسن من فهم الطلابب للنيادة

The advantages of using

electronic tools outweighs the disadvantages of not using them.

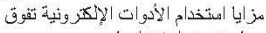

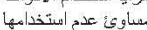

Using electronic tools such as Facebook, Podcasts, Videos,

Skype to communicate with

students and for instruction is a good idea.

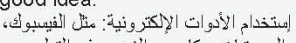

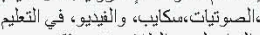

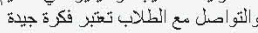


Please rate the statements below related to your perceptions about electronic tools by choosing the following descriptors: Strongly Agree, Agree, Neither Agree or Disagree, Disagree, Strongly Disagree. Electronic tools for this question are defined as social media tools (ex. Facebook, Twitter), productivity software (ex. Word, Excel, Powerpoint), video conferencing software (ex. Skype) and other electronic technologies that can be used for communicating with students and for instruction.

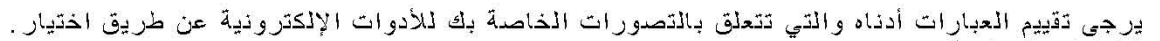

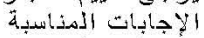

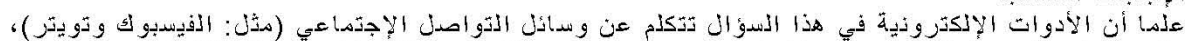

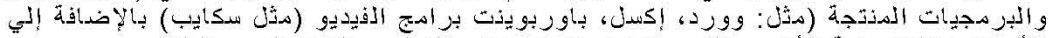

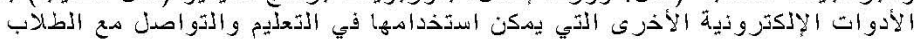

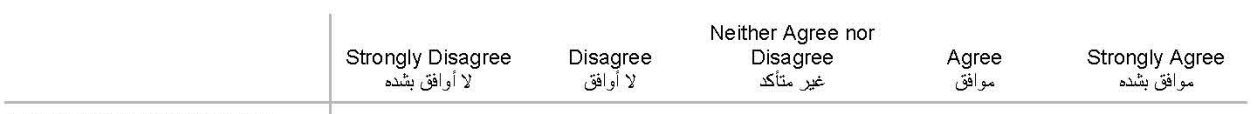

I have the basic skills to use

social networking software like

Facebook or Twitter

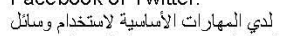

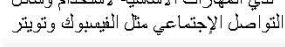

I am skillful in using social

media and productivity

electronic tools (e.g. Twitter,

Facebook, podcasts, videos)

for communicating with

students and for Instruction.

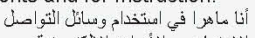

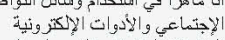

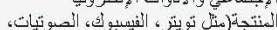

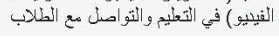

Using technology will have a

positive impact on my career

as a professor.

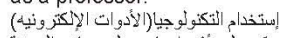

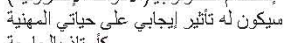

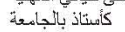

The use of technological tools is important for conducting professional work

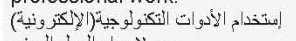

مهي لإجراء الكعل المهني

Using social media tools and productivity electronic tools to

communicate with students

and for instruction is stressful.

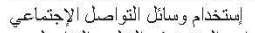

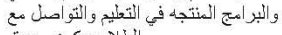
انطلاب يكون مز هن

I have access to a computer with productivity software (e.g. Word, Adobe Acrobate, Excel).

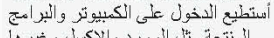

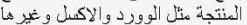

I have the basic skills for

navigating the Internet (e.g.

Accessing information through

the use of search engines

entering passwords to access

websites).

لدي السهاراث الأساسية لاستخدام الإنتزنت

https://m ontana.qualtrics.com/jfe/previewF orm/SV_6njsVneFrg2S4PH 
114

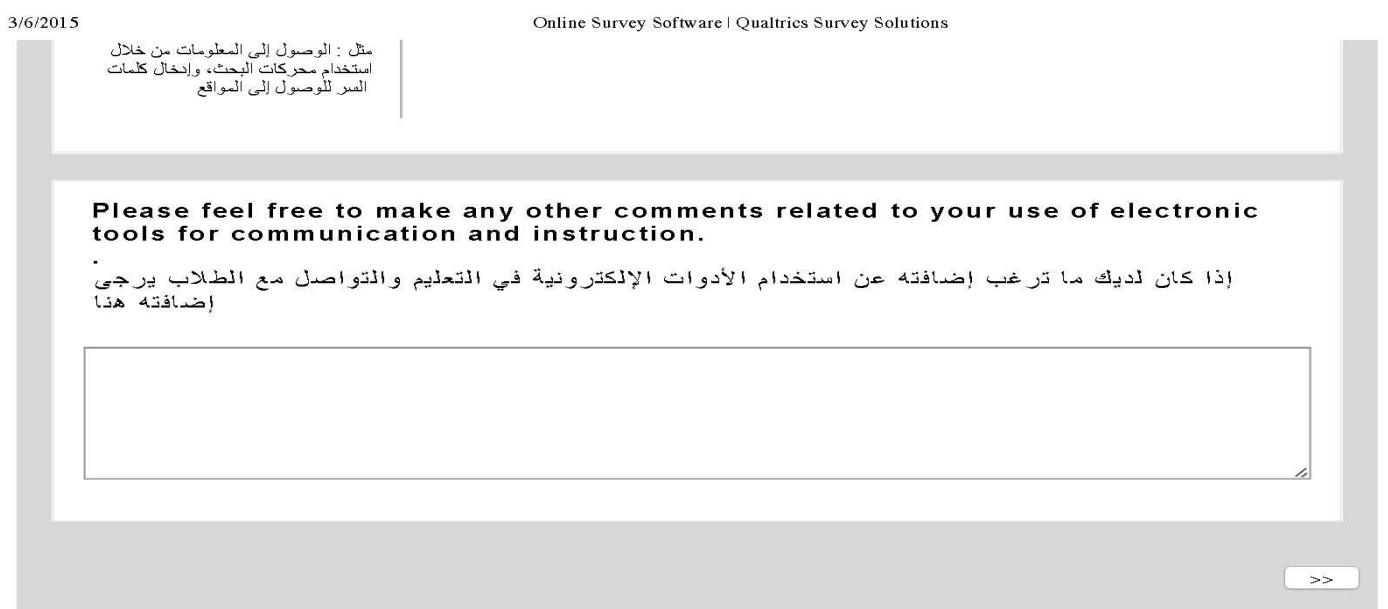


115

APPENDIX C

INSTITUTIONAL REVIEW BOARD 


\section{N MOTITE UNIVERSITY}

MEMORANDUM

TO: $\quad$ Mabark Alshahri and Art Bangert

FROM: Mark Quinn, Chair Thark guenin ey'

DATE: October 27, 2014

RE: $\quad$ "Investigating Saudi and US Faculty Use of Electronic Tools to Support Teaching and Learning"

The above research, described in your submission of October 23,2014 , is exempt from the requirement of review by the Institutional Review Board in accordance with the Code of Federal regulations, Part 46, section 101. The specific
paragraph which applies to your research is:

- (b) (1) Research conducted in established or commonly accepted educational settings, involving normal educational practices such as (i) research on regular and special education instructional strategies, or (ii)
research research on the effectiv
management methods.

$\times \quad$ (b) (2)

Research involving the use of educational tests (cognitive, diagnostic, aptitude, achievement), survey procedures, interview procedures or observation of public behavior, unless: (i) information obtained is
recorded in such a manner that human subjects can be identified, directly or through identifiers linked to the subjects; and (ii) any disclosure of the human subjects' responses outside the research could reasonably place the subjects at risk of criminal or civil liability, or be damaging to the subjects' financial standing. employability, or reputation.

(b) (3) Research involving the use of educational tests (cognitive, diagnostic, aptitude, achievement), survey procedures, interview procedures, or observation of public behavior that is not exempt under paragraph
(b)(2) of this section, if: (i) the human subjects are elected or appointed public officials or candidates for (b)(2) of this section, if: (i) the human subjects are elected or appointed public officials or candidates for
public office; or (ii) federal statute(s) without exception that the confidentiality of the personally identifiable
information will be maintained throughout the research and thereafter.

(b) (4) Research involving the collection or study of existing data, documents, records, pathological specimens, or diagnostic specimens, if these sources are publicly available, or if the information is recorded by the
investigator in such a manner that the subjects cannot be identified, directly or through identifiers linked to
the subjects.

(b) (5) Research and demonstration projects, which are conducted by or subject to the approval of department or service programs; (ii) procedures for obtaining benefits or services under those programs; (iii) possible changes in or alternatives to those programs or procedures; or (iv) possible changes in methods or levels of
payment for benefits or services under those programs.

(b) (6) Taste and food quality evaluation and consumer acceptance studies, (i) if wholesome foods without additives are consumed, or (ii) if a food is consumed that contains a food ingredient at or below the level
and for a use found to be safe, or agricultural chemical or environmental contaminant at or below the leve
found to be safe, by the FDA, or approved by the EPA, or the Food Safety and Inspection Service of the YSDA.

Although review by the Institutional Review Board is not required for the above research, the Committee will be glad to processed by expedited review. 


\section{SUBJECT CONSENT FORM FOR \\ MIPATION IN HUMAN RESEARCH AT}

Dear Participant

My name is Mabark Alshari and I am a doctoral candidate at Montana State University. I am inviting you to be a part of a research study. This consent form will provide the information that you need in order to make an informed decision about whether you would like to participate in the study. The study will consist of a survey that should take approximately 5 to 10 minutes of your time. Once you have obtained sufficient in this study.

Project Title: Investig
Teaching and Learning.

Purpose of the research study: You are being asked to participate in a research study to investigate the types of electronic tools Saudi and US faculty use for instruction. In addition, this study will also examine faculty perceptions of the usefulness of electronic tools as well as their ease of use.

Voluntary participation: Your participation in this research is completely voluntary and you can choose to not answer any questions you do not want to answer and/or you can
stop at any time.

Procedures involved: This study consists of a survey administered online. There are several different sections in this survey. The first section asks you to rate your frequency that you rate the usefulness of electronic tond and third sections of the survey request responses about your use of electronic tools for instruction. You may choose to not answer any questions you do not want to answer and/or you can stop at any time. The responses you provide are anonymous and will not be linked to any personal information. No identifying information will be collected fro this study. Email addresses form the electronic survey will be stripped from the data file prior to analysis to ensure respondent anonymity and confidentiality. Only group results will be reported for this research project.

Risks and Benefits: If you feel discomfort about any of the questions, you may choose to leave items blank or to terminate your participation in the survey. The study is of no benefit to you.

Right to

Source of Funding: NA 


\section{8}

Cost to Subject: None

Confidentiality: There will be no identifying information collected, as the survey is anonymous.

Whom to contact if you have questions about the study

If you have questions about this study, please contact Mabark Alshahri at (406) 580-9944 or at Mabark@me.com Additional questions about the rights of human subjects can be 4707 or at mquinn@montana.edu

AUTHORIZATION: I have read the above and understand the discomforts, inconvenience and risk of this study. By pressing the "Continue Survey" button, I agree to participate in this research. I understand that I may later refuse to participate, and that I may withdraw from the study at any time. I have received a copy of this consent form for 